\title{
ÆUSGS
}

science for a changing world

Prepared in cooperation with the South Carolina Geological Survey

\section{Detailed Lithologic Logs from Auger Holes in Southern Charleston County, Southwestern Dorchester County, and Eastern Colleton County, South Carolina}

By Robert E. Weems and William C. Lewis

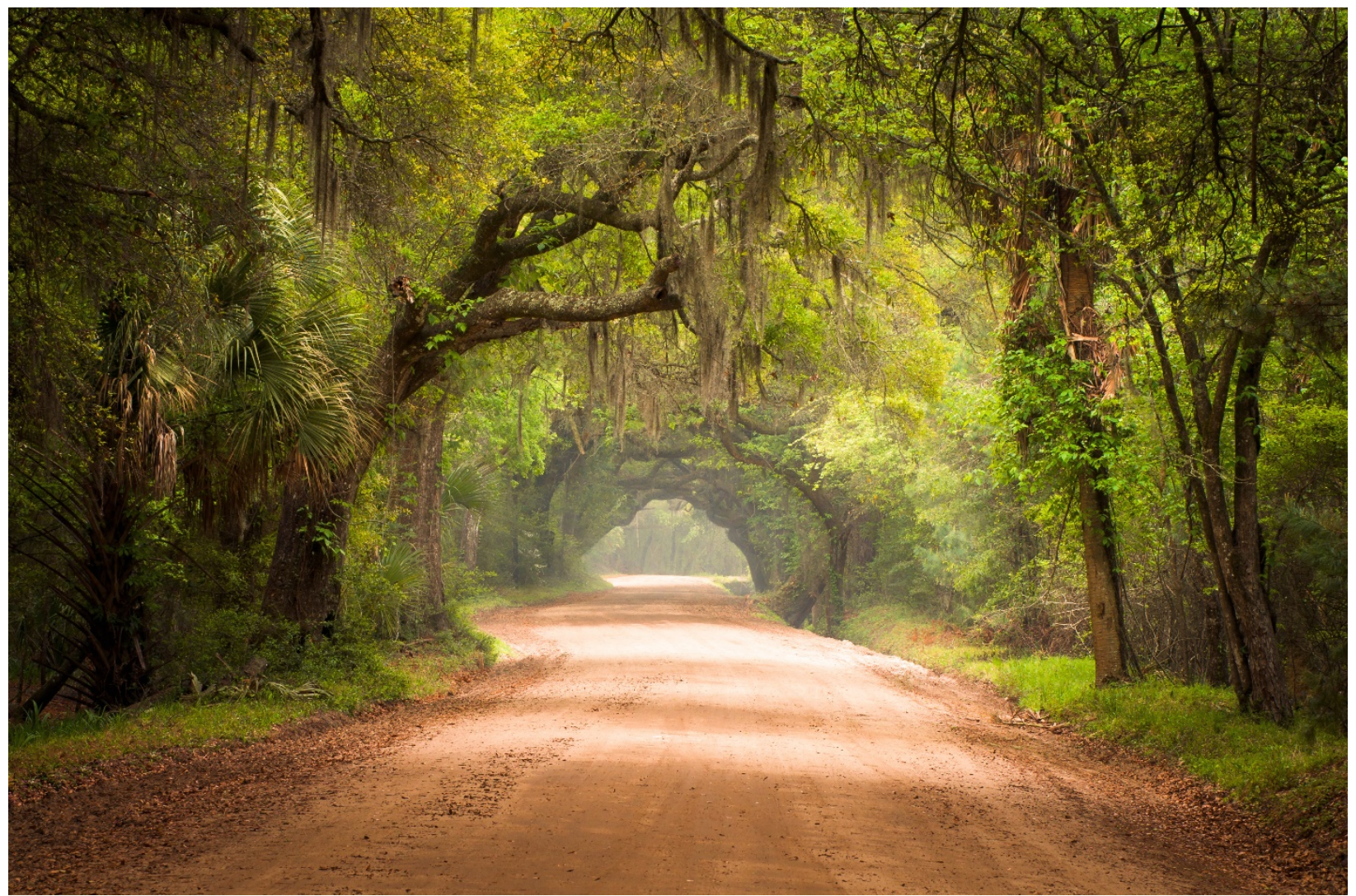

Open-File Report 2019-1119

U.S. Department of the Interior

U.S. Geological Survey 
Cover. Tunnel of live oak trees at the entrance of Botany Bay Plantation Heritage Preserve and Wildlife Management Area, Edisto Island, South Carolina. This very flat but often picturesque terrain is typical of the South Carolina Low Country.

Photograph by Dave Allen, Dave Allen Photography (http://daveallenphotography.com/deep_south.php). 


\section{Detailed Lithologic Logs from Auger Holes in Southern Charleston County, Southwestern Dorchester County, and Eastern Colleton County, South Carolina}

By Robert E. Weems and William C. Lewis

Open-File Report 2019-1119

Prepared in cooperation with the South Carolina Geological Survey 


\title{
U.S. Department of the Interior \\ DAVID BERNHARDT, Secretary
}

\author{
U.S. Geological Survey \\ James F. Reilly II, Director
}

U.S. Geological Survey, Reston, Virginia: 2019

For more information on the USGS - the Federal source for science about the Earth, its natural and living resources, natural hazards, and the environment-visit https://www.usgs.gov/ or call 1-888-ASK-USGS (1-888-275-8747).

For an overview of USGS information products, including maps, imagery, and publications, visit https://store.usgs.gov/.

Any use of trade, firm, or product names is for descriptive purposes only and does not imply endorsement by the U.S. Government.

Although this information product, for the most part, is in the public domain, it also may contain copyrighted materials as noted in the text. Permission to reproduce copyrighted items must be secured from the copyright owner.

Suggested citation:

Weems, R.E., and Lewis, W.C., 2019, Detailed lithologic logs from auger holes in southern Charleston County, southwestern Dorchester County, and eastern Colleton County, South Carolina: U.S. Geological Survey Open-File Report 2019-1119, 129 p., https://doi.org/10.3133/ofr20191119.

ISSN 2331-1258 (online) 


\section{Acknowledgments}

The authors would like to thank William R. Doar, III (South Carolina Geological Survey) and Peter G. Chirico (U.S. Geological Survey) for reviewing this manuscript and making many helpful improvements to it. Natalie Juda performed an exceptionally thorough editorial review of the final manuscript and made many very useful improvements to its format and content. The authors are deeply indebted to all these people for their efforts on his behalf. 


\section{Contents}

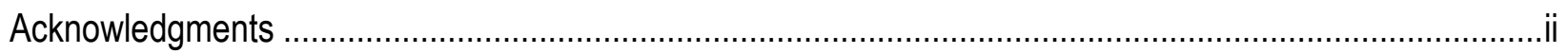

Introduction

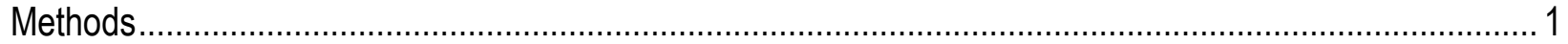

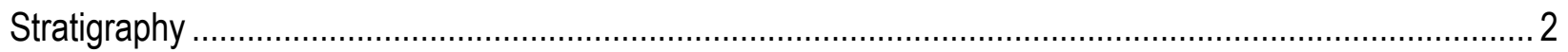

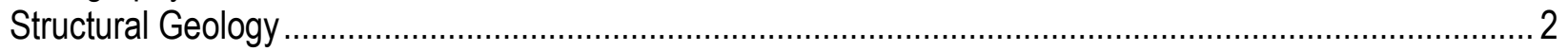

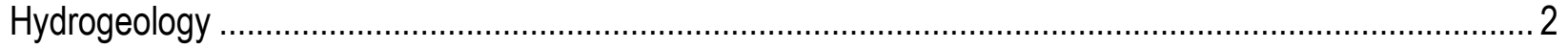

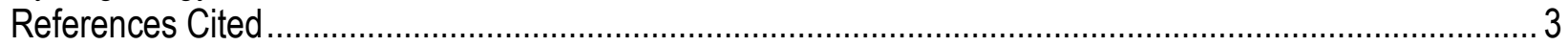

Appendix 1. Locality Descriptions and Detailed Lithologic Logs ......................................................... 10

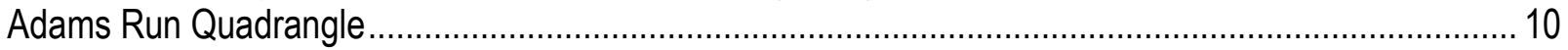

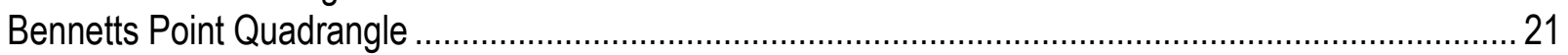

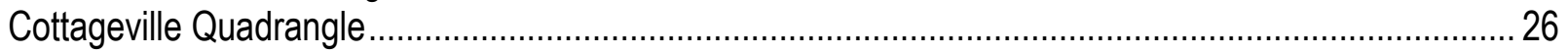

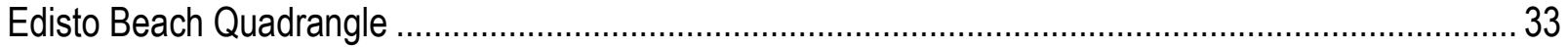

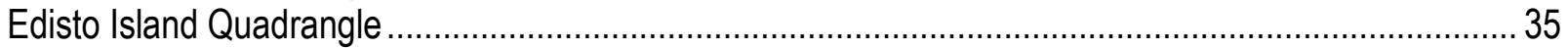

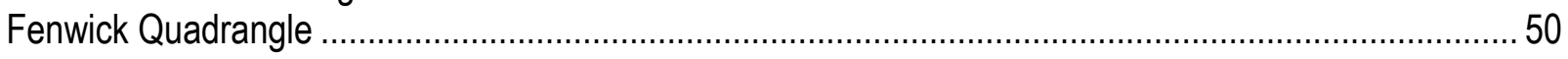

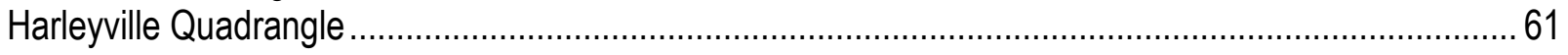

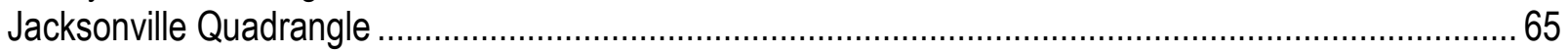

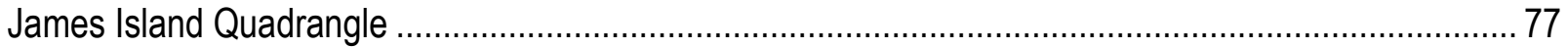

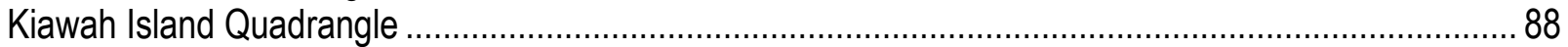

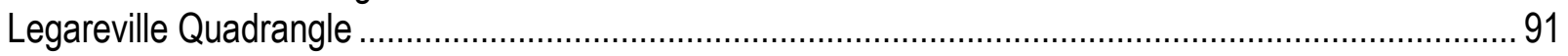

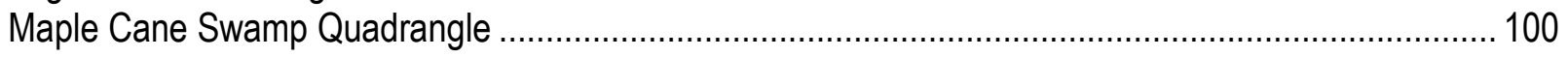

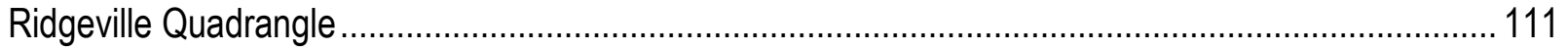

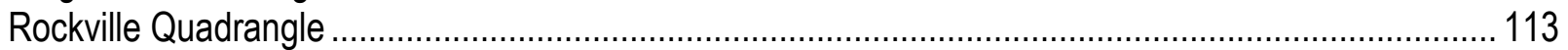

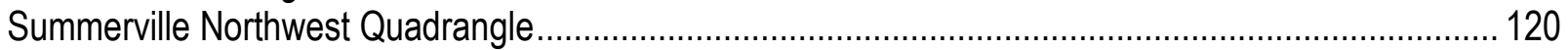

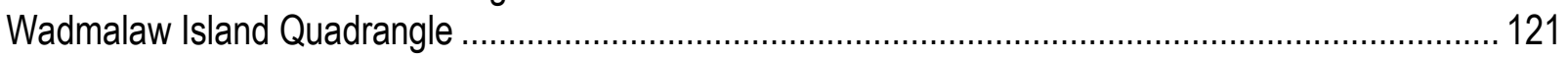

\section{Figures}

1. Map of the part of the study area in the northwest portion of the 1:100,000 Charleston region map sheet.....................................................................................................

2. Map of the part of the study area in the southwest portion of the 1:100,000 Charleston

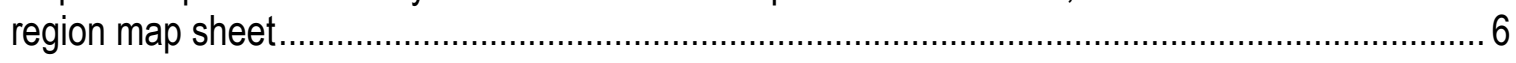

\section{Tables}

1. Age and relative position of Paleogene and Neogene stratigraphic units penetrated

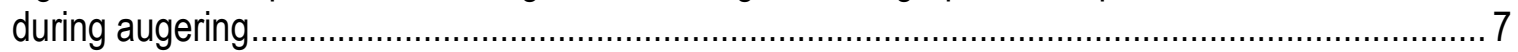

2. Nomenclature and recognized geomorphic framework for Quaternary units in the study area from highest down to lowest. 


\section{Conversion Factors}

\begin{tabular}{|c|c|c|}
\hline Multiply & By & To obtain \\
\hline \multicolumn{3}{|c|}{ Length } \\
\hline inch (in.) & 2.54 & centimeter $(\mathrm{cm})$ \\
\hline inch (in.) & 25.4 & millimeter (mm) \\
\hline foot (ft) & 0.3048 & meter $(\mathrm{m})$ \\
\hline mile (mi) & 1.609 & kilometer $(\mathrm{km})$ \\
\hline mile, nautical (nmi) & 1.852 & kilometer $(\mathrm{km})$ \\
\hline yard (yd) & 0.9144 & meter (m) \\
\hline centimeter $(\mathrm{cm})$ & 0.3937 & inch (in.) \\
\hline millimeter (mm) & 0.03937 & inch (in.) \\
\hline meter $(\mathrm{m})$ & 3.281 & foot $(\mathrm{ft})$ \\
\hline kilometer (km) & 0.6214 & mile (mi) \\
\hline kilometer $(\mathrm{km})$ & 0.5400 & mile, nautical (nmi) \\
\hline meter $(\mathrm{m})$ & 1.094 & yard (yd) \\
\hline
\end{tabular}




\title{
Detailed Lithologic Logs from Auger Holes in southern Charleston County, southwestern Dorchester County, and eastern Colleton County, South Carolina
}

\author{
By Robert E. Weems and William C. Lewis
}

\section{Introduction}

The lithologic logs described in this open-file report are from holes augered in the South Carolina Low Country in parts of Charleston, Dorchester, and Colleton Counties from 1998 through 2010. This region comprises the southernmost and westernmost portions of the area included in the 1:100,000 Charleston region geologic map by Weems and others (2014). Logs of the remainder of that map area were published prior to its release (Weems and Lemon, 1985; Weems and others, 1985a, b, c, 1987a, b, c; Weems and Lewis, 1997). The present report completes the lithologic log record from which the 1:100,000 Charleston region geologic map largely was compiled.

\section{Methods}

Auger hole sites were selected to provide uniform areal density of coverage within the map area (to the degree that this was possible) and to provide optimal accuracy of surface elevations at auger sites. Surface elevations for each drill site were obtained by hand leveling from a known elevation, commonly a bench mark or spot elevation point on the appropriate 7.5-minute quadrangle. Lithologic data were gathered at each test site by augering with a truckmounted, Mobile Drill B-40 power auger equipped with solid stem 5-ft-long auger flight sections. First, one flight was advanced 5 feet into the ground (using clockwise rotation) and then extracted to the surface (without rotation). Once at the surface, the soil profile was described. Subsequent runs added one, two, or three new flights, depending on depth and the ease of augering. The sample rise on the drill stems was kept to a minimum for greater accuracy.

Auger holes generally targeted the upper few feet of the lower Oligocene Ashley Formation or other formations of the upper Eocene to lower Oligocene Cooper Group if the Ashley Formation was not present at that site (see table 1 for stratigraphic context of these units). Occasionally, however, auger holes went deeper where greater stratigraphic control was needed. Lithologic descriptions were made by using a 10X hand lens, grain-size chart, and color charts. Auger site locations were plotted on 7.5-minute topographic maps. Latitude and longitude coordinates were established by using published U.S. Geological Survey maps (North American Datum of 1927). 


\section{Stratigraphy}

A full listing of the Paleogene and Neogene stratigraphic units penetrated during augering within this study area, their ages, and their general lithologic descriptions are given in table 1. The updated nomenclature used for the Cooper Group is taken from Weems and others (2016). In a few limited areas in the Cottageville, Harleyville, and Maple Cane Swamp quadrangles, there are outcrops of the Ashley Formation and the upper Pliocene Goose Creek Limestone. Elsewhere in the study area, outcrops of the surficial geologic units in this region are entirely composed of Pleistocene and Holocene materials. These units and their associated geomorphic features are given in table 2. One previously informal Pleistocene unit, the "Ten Mile Hill beds," has been formalized as the "Ten Mile Hill Formation" (Sanders and others, 2009). The major waterways often have subcrops of pre-Pleistocene strata, which locally have produced important fossil finds (for example, Godfrey and others, 2016). In the Bennetts Point quadrangle, divers have recovered mysticete whale remains that represent a species elsewhere known only from the early Pliocene (Zanclean) Sunken Meadow Member of the Yorktown Formation and the ageequivalent Bone Valley Member of the Peace River Formation of Florida (Robert Boessenecker, College of Charleston, written commun., 2017). The only early Pliocene deposits known from South Carolina are the "Wabasso beds" of Huddlestun (1988), so this discovery strongly suggests that Wabasso beds occur locally in the subsurface of the Bennetts Point quadrangle, even though they were not encountered during exploratory augering.

\section{Structural Geology}

Because most of the study region is at low elevation and has very limited outcrops, its structural geology remains poorly known. The Adams Run fault and dome (Weems and Lewis, 2002) suggest that there is a major north-south antiform just to the east of the lower Edisto River. It seems self-evident that this structure controls the location of the lower reaches of that river. There are also domes in the vicinity of James Island (Weems and Lewis, 2002) and another beneath Beaufort, S.C., to the south of this study area (Colquhoun and Johnson, 1968). These features indicate that there is a structural framework present in this area that is yet to be fully elucidated and understood.

\section{Hydrogeology}

The base of the surficial aquifer in this region generally lies at the base of the Pleistocene or, if present, Pliocene deposits, which are poorly consolidated and typically sandy to gravelly near their base. Structure contours on the base of this aquifer are shown on the 1:100,000 Charleston region geologic map by Weems and others (2014). 


\section{References Cited}

Colquhoun, D.J., and Johnson, H.S., Jr., 1968, Tertiary sea-level fluctuation in South Carolina: Palaeogeography, Palaeoclimatology, Palaeoecology, v. 5, no. 1, p. 105-126.

Godfrey, S.J., Uhen, M.D., Osborne, J.E., and Edwards, L.E., 2016, A new specimen of Agorophius pygmaeus (Agorophiidae, Odontoceti, Cetacea) from the early Oligocene Ashley Formation of South Carolina, USA: Journal of Paleontology, v. 90, no. 1, p. 154-169. Huddlestun, P.F., 1988, A revision of the lithostratigraphic units of the Coastal Plain of Georgia-The Miocene through Holocene: Georgia Geologic Survey Bulletin 104, 162 p.

Sanders, A.E., Weems, R.E., and Albright, L.B., III, 2009, Formalization of the middle Pleistocene "Ten Mile Hill beds" in South Carolina with evidence for placement of the Irvingtonian-Rancholabrean boundary, in Albright, L.B., III, ed., Papers on geology, vertebrate paleontology, and biostratigraphy in honor of Michael O. Woodburne: Museum of Northern Arizona Bulletin 65, p. 363-370.

Weems, R.E., Albright, L.B., Bybell, L.M., Cicimurri, D.J., Edwards, L.E., Harris, W.B., Lewis, W.C., Osborne, J.E., Sanders, A.E., and Self-Trail, J.M., 2016, Stratigraphic revision of the Cooper Group and the Chandler Bridge and Edisto Formations in the Coastal Plain of South Carolina: South Carolina Geology, v. 49, p. 1-24.

Weems, R.E., Gohn, G.S., and Houser, B.B., 1987a, Additions and revisions to the auger hole records for the Cainhoy and Charleston quadrangles, South Carolina: U.S. Geological Survey Open-File Report 87-362, 22 p.

Weems, R.E., and Lemon, E.M., Jr., 1985, Detailed sections from auger holes and outcrops in the Cainhoy, Charleston, and Fort Moultrie quadrangles, South Carolina: U.S. Geological Survey Open-File Report 85-378, 65 p.

Weems, R.E., Lemon, E.M., Jr., and Cron, E.D., 1985a, Detailed sections from auger holes and outcrops in the Bethera, Cordesville, Huger, and Kittredge quadrangles, South Carolina: U.S. Geological Survey Open-File Report 85-439, 85 p.

Weems, R.E., Lemon, E.M., Jr., Gohn, G.S., and Houser, B.B., 1985c, Detailed sections from auger holes and outcrops in the Ladson, Moncks Corner, Mount Holly, and Stallsville quadrangles, South Carolina: U.S. Geological Survey Open-File Report 85-472, 103 p.

Weems, R.E., Lemon, E.M., Jr., Gohn, G.S., and Houser, B.B., 1987b, Detailed sections from auger holes and outcrops in the Clubhouse Crossroads, Johns Island, Osborn, and Ravenel quadrangles, South Carolina: U.S. Geological Survey Open-File Report 87-661, 159 p.

Weems, R.E., Lemon, E.M., Jr., and McCartan, L., 1985b, Shallow subsurface geology of the North Charleston 7.5-minute quadrangle, South Carolina: U.S. Geological Survey Open-File Report 85-274, variously paged, 1 pl.

Weems, R.E., Lemon, E.M., Jr., Nelson, M.S., Gohn, G.S., and Houser, B.B., 1987c, Detailed sections from auger holes and outcrops in the Pringletown, Ridgeville, Summerville Northwest, and Summerville quadrangles, South Carolina: U.S. Geological Survey Open-File Report 87-524, 89 p.

Weems, R.E., and Lewis, W.C., 1997, Detailed geologic sections from auger holes in northeastern Charleston County, South Carolina, east of $79^{\circ} 45^{\prime}$ west longitude: U.S. Geological Survey Open-File Report 97-712-A, 82 p., 1 CD-ROM.

Weems, R.E., and Lewis, W.C., 2002, Structural and tectonic setting of the Charleston, South Carolina, region-Evidence from the Tertiary stratigraphic record: Geological Society of America Bulletin, v. 114, no. 1, p. 24-42. 
Weems, R.E., Lewis, W.C., and Lemon, E.M., Jr., 2014, Surficial geologic map of the Charleston region, Berkeley, Charleston, Colleton, Dorchester, and Georgetown Counties, South Carolina: U.S. Geological Survey Open-File Report 2013-1030, 1 sheet, scale $1: 100,000$.

Willoughby, R.H., and Doar, W.R., III, 2006, Solution to the two-Talbot problem of marine Pleistocene terraces in South Carolina: Geological Society of America Abstracts with Programs, v. 38, no. 3, p. 18. 


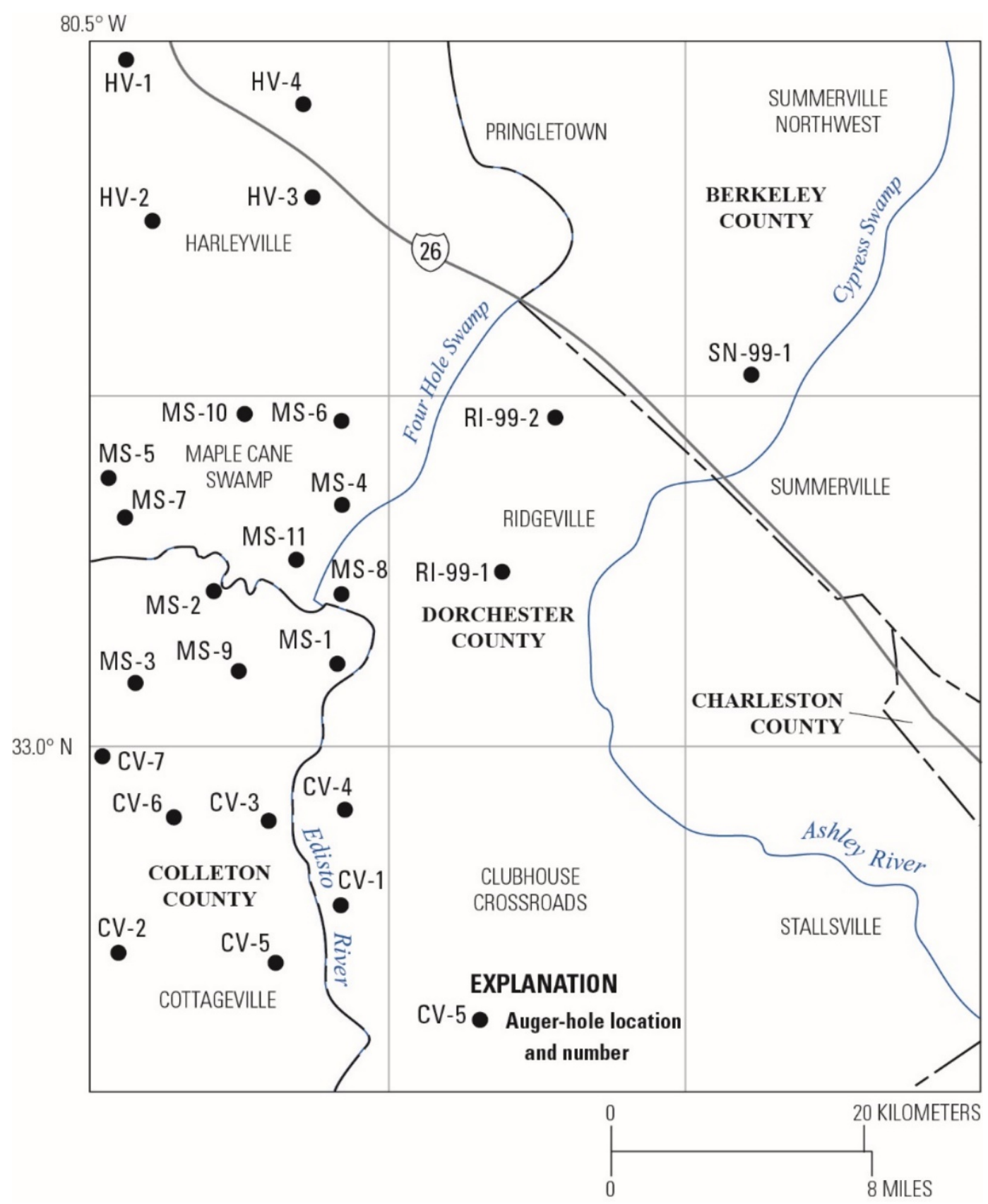

Figure 1. Map of the part of the study area in the northwest portion of the 1:100,000 Charleston region map sheet (Weems and others, 2014), showing boundaries and locations of relevant 7.5-minute topographic quadrangle maps, county names and boundaries, and auger-hole locations (small black circles) and their field reference numbers. 


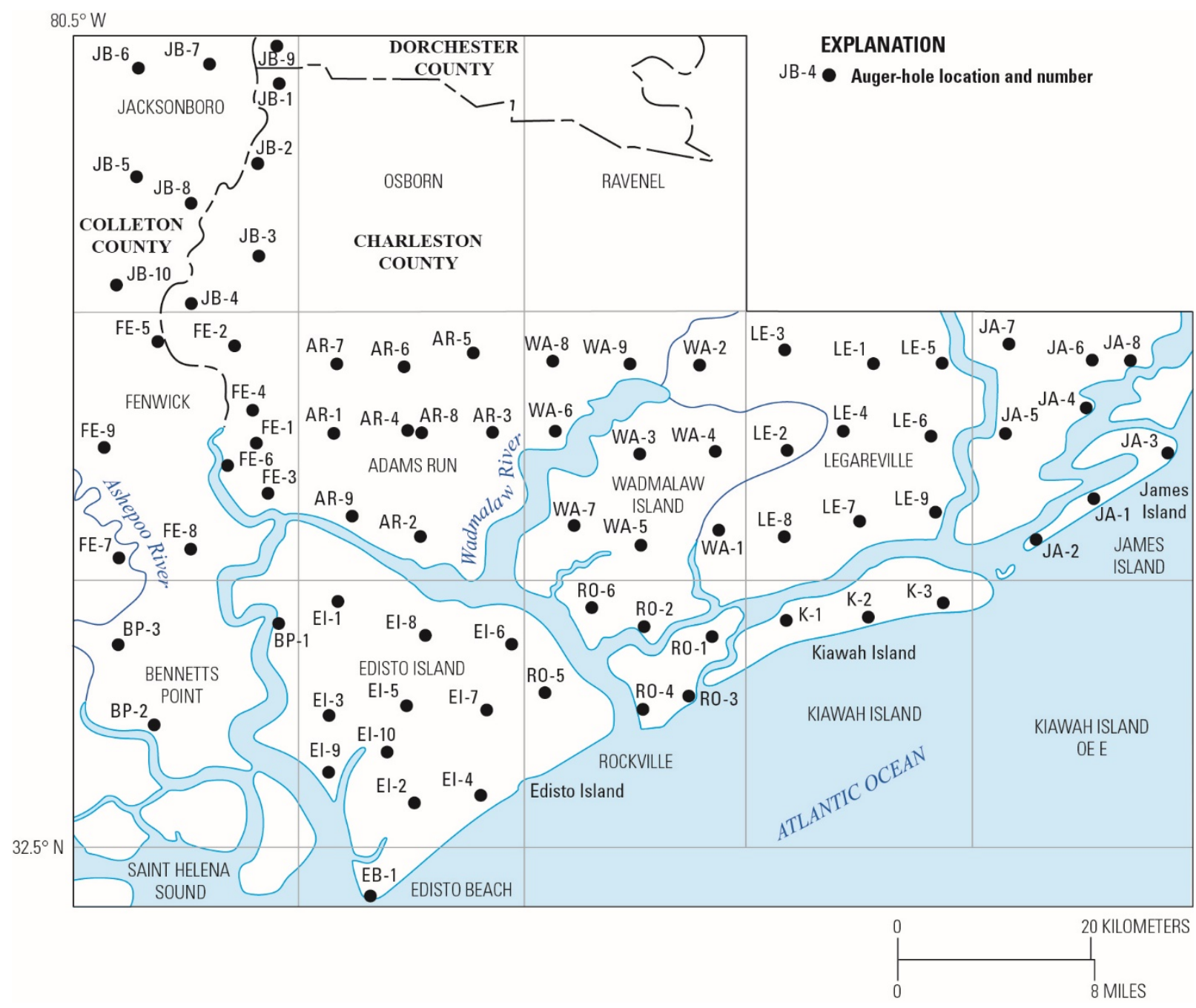

Figure 2. Map of the part of the study area in the southwest portion of the 1:100,000 Charleston region map sheet (Weems and others, 2014), showing boundaries and locations of relevant 7.5-minute topographic quadrangle maps, county names and boundaries, and auger-hole locations (small black circles) and their field reference numbers. 
Table 1. Age and relative position of Paleogene and Neogene stratigraphic units penetrated during augering.

\begin{tabular}{|c|c|c|}
\hline Unit & Age & Lithology \\
\hline Raysor Formation & Upper Pliocene & Shelly sands to sandy coquina \\
\hline Goose Creek Limestone & Upper Pliocene & Shelly limestone \\
\hline Marks Head Formation & Lower Miocene & Clayey fine sand to sandy clay \\
\hline Parachucla Shale & Lower Miocene & Semilithified siltstone and shale \\
\hline Edisto Formation & Upper Oligocene & Fine to medium shelly sands and sandy limestones \\
\hline Chandler Bridge Formation ${ }^{1}$ & Upper Oligocene & Fine to medium phosphatic sands \\
\hline $\begin{array}{l}\text { Ashley Formation, } \\
\text { Givhans Ferry Member }\end{array}$ & Lower Oligocene & Quartzose and phosphatic fine foraminiferal calcarenite \\
\hline $\begin{array}{l}\text { Ashley Formation, } \\
\text { Runnymede Marl Member }\end{array}$ & Lower Oligocene & Fine foraminiferal calcarenite \\
\hline $\begin{array}{l}\text { Harleyville Formation, } \\
\text { Osborn Member }\end{array}$ & Upper Eocene & Variably shelly fine calcarenite \\
\hline Parkers Ferry Formation & Upper Eocene & Calcilutite to calcisiltite often with echinoid spines \\
\hline $\begin{array}{l}\text { Tupelo Bay Formation, } \\
\text { Pregnall Member }\end{array}$ & Upper Eocene & Variably shelly limestones \\
\hline
\end{tabular}

${ }^{1}$ Within map area, but not augered. 
Table 2. Nomenclature and recognized geomorphic framework for Quaternary units in the study area from highest (oldest) down to lowest (youngest) (adapted from Willoughby and Doar, 2006).

\begin{tabular}{|c|c|c|c|}
\hline Unit & Overlying surface & Maximum elevation (feet) & Intervening scarp \\
\hline & & & Parler scarp \\
\hline \multirow[t]{2}{*}{ Waccamaw Formation (?) } & Okefenokee terrace & 137 & \\
\hline & & & Surry scarp \\
\hline \multirow[t]{2}{*}{ Wicomico formation } & Wicomico terrace & 105 & \\
\hline & & & Dorchester scarp \\
\hline \multirow[t]{2}{*}{ Daniel Island beds } & (subsurface only) & ----- & \\
\hline & & & ----- \\
\hline \multirow[t]{2}{*}{ Penholoway formation } & Penholoway terrace & 75 & \\
\hline & & & Macbeth scarp \\
\hline \multirow[t]{2}{*}{ Ladson Formation } & Cordesville terrace & 57 & \\
\hline & & & Bethera scarp \\
\hline \multirow[t]{2}{*}{ Ten Mile Hill Formation } & Talbot terrace & 35 & \\
\hline & & & Suffolk scarp \\
\hline \multirow[t]{2}{*}{ Wando Formation, lower member } & Pamlico terrace & 25 & \\
\hline & & & Awendaw scarp \\
\hline Wando Formation, middle member & (subsurface only) & ----- & \\
\hline \multirow[t]{2}{*}{ Wando Formation, upper member } & Princess Anne terrace & 17 & \\
\hline & & & Mt. Pleasant scarp \\
\hline Silver Bluff beds & Silver Bluff terrace & 7 & \\
\hline \multicolumn{4}{|l|}{ Modern river alluvium } \\
\hline \multicolumn{4}{|l|}{ Modern barrier island beach sands } \\
\hline \multicolumn{4}{|l|}{ Modern tidal marsh muds } \\
\hline Artificial fill & & & \\
\hline
\end{tabular}




\section{Appendix}




\section{Appendix 1. Locality Descriptions and Detailed Lithologic Logs}

(Sands are subangular to subrounded quartz sands unless otherwise indicated. Abbreviations used: cm, centimeter; ft, foot; in., inch; mi, mile; NP, calcareous nannofossil zone)

\section{Adams Run Quadrangle}

AR-1: $1.1 \mathrm{mi}$ east of western quadrangle border, $4.0 \mathrm{mi}$ south of northern quadrangle border, in west-central 1/9th of the quadrangle (latitude $32.6920^{\circ}$ N., longitude $80.3558^{\circ}$ W.). Surface elevation $22 \mathrm{ft}$.

\section{LITHOLOGY}

DEPTH, IN FEET

\section{Wando Formation, upper member}

Sand, fine, well-sorted, clean grading downward to silty; sparse very fine, dark heavy-mineral grains present; dark yellowish orange $(10 Y R$ 6/6) grading downward through pale red $(10 R 6 / 2)(2-3 \mathrm{ft})$ and through pale brown $(5 Y R 5 / 2)(3-6 \mathrm{ft})$ to light olive gray $(10 Y 5 / 2)$ $0-9$

Silt, clayey, sandy, sparsely shelly, medium-bluish-gray $(5 B 5 / 1)$

Sand, fine, silty, sparsely shelly; sparse very fine, dark heavy-mineral grains present; light olive gray $(10 Y 5 / 2)$ grading downward at $16 \mathrm{ft}$ to greenish gray $(5 G Y 5 / 1)$

Silt, clayey, sandy, greenish-gray (5GY 5/1)

Sand, fine, well-sorted, silty, shelly, greenish-gray ( $5 G Y 5 / 1)$; very fine to fine, dark heavy-mineral grains abundant; scattered medium grains of rounded phosphate sand present.

Sand, fine to medium, greenish-gray ( $5 G Y 5 / 1)$; contains rounded phosphate granules and one polished quartz pebble about $1 \mathrm{~cm}$ in diameter

\section{UNCONFORMITY}

\section{Marks Head Formation}

Sand, fine; phosphate sand moderately abundant; micaceous below $41 \mathrm{ft}$; olive brown (5Y3/4) grading downward through light olive gray $(5 Y 5 / 2)(41-44 \mathrm{ft})$ and then back to olive brown $(5 Y 3 / 4)$.

Hard bed; drill bit spun for a while and then punched through; no recovery

UNCONFORMITY

\section{Ashley Formation, Givhans Ferry Member}

Sand, very calcareous and phosphatic; abundant subrounded phosphate pebbles up to $4 \mathrm{~cm}$ in diameter in basal $1 \mathrm{ft}$ and in burrows in upper $1 \mathrm{ft}$ of unit below; light olive brown $(5 Y 5 / 4)$ grading rapidly downward to moderate olive brown $(5 Y 4 / 4)$ 
Harleyville Formation, Osborn Member

Calcarenite, very fine to fine, clayey; grayish yellow (5Y 7/4) grading

rapidly downward to light olive brown (5Y 5/4).....

$63-66$

Base of Wando Formation, upper member:

Base of Marks Head Formation:

Base of Ashley Formation, Givhans Ferry Member:

$-16 \mathrm{ft}$ below sea level

$-35 \mathrm{ft}$ below sea level

$-41 \mathrm{ft}$ below sea level

Bottomed in Harleyville Formation, Osborn Member 
AR-2: $3.4 \mathrm{mi}$ west of eastern quadrangle border, $1.4 \mathrm{mi}$ north of southern quadrangle border, in south-central 1/9th of the quadrangle (latitude $32.6456^{\circ}$ N., longitude $80.3082^{\circ}$ W.). Surface elevation $12 \mathrm{ft}$.

\section{LITHOLOGY}

DEPTH, IN FEET

\section{Wando Formation, upper member}

Sand, fine, well-sorted, silty and a bit clayey; pseudoplinthite nodules present near base; yellowish brown (10YR 3/2) grading downward through pale yellowish brown (10YR 6/2) to grayish orange (10YR 6/4) and mottled orange (10YR 6/4)

Sand, fine, silty; contains sparse very fine, dark heavy-mineral grains and medium-size silvery mica flakes; dark yellowish orange (10YR 6/6) and mottled very pale orange (10YR $8 / 2)$

Sand, very fine, silty and clayey; greenish gray $(5 G Y$ 6/1) and mottled dark yellowish orange $(10 Y R$ 6/6)

Sand, fine, silty; contains sparse very fine, dark heavy-mineral grains and medium-size silvery mica flakes; light yellowish gray $(5 Y 7 / 2)$ and mottled dark yellowish orange (10YR 6/6) grading downward through grayish yellow (5Y 7/4) (11-16 ft) to yellowish gray (5Y 6/2)

Sand, fine to medium grading downward through fine and then back to fine to medium, silty, greenish-gray ( $5 G Y 5 / 1)$; contains scattered rounded coarse grains; silt lens present at $36 \mathrm{ft}$

Sand, medium to coarse, subrounded to rounded, slightly silty, greenish-gray $(5 G Y 5 / 1)$

\section{UNCONFORMITY}

\section{Harleyville Formation, Osborn Member}

Very hard bed; spun 45 minutes to punch through it; no recovery

Calcarenite, fine, silty, light-olive-brown ( $5 Y 5 / 4)$; sharp contact with unit below

-UNCONFORMITY

\section{Parkers Ferry Formation}

Calcisiltite, clayey; grading downward to calcilutite, silty, very stiff and

dense, hard to cut off stems; light grayish olive (10Y 5/2) $60-76$

Base of Wando Formation, upper member: Base of Harleyville Formation, Osborn Member:

\section{Bottomed in Parkers Ferry Formation}


AR-3: $1.05 \mathrm{mi}$ west of eastern quadrangle border, $3.8 \mathrm{mi}$ south of northern quadrangle border, in east-central 1/9th of the quadrangle (latitude $32.6933^{\circ}$ N., longitude $80.2684^{\circ}$ W.). Surface elevation $17 \mathrm{ft}$.

\section{LITHOLOGY}

DEPTH, IN FEET

\section{Wando Formation, upper member}

Sand, fine, well-sorted, silty; dusky brown (5YR 2/2) grading

downward to dusky yellow $(5 Y 6 / 4)$

Sand, fine, well-sorted, silty; very fine, dark heavy-mineral grains and coarse-size silvery mica flakes present; dark yellowish orange

(10YR 6/6) and mottled grayish yellow (5Y 7/4)

Silt, clayey and sandy (very fine), stiff and sticky, greenish-gray (5G 7/1)

Sand, fine, silty; contains very fine, dark heavy-mineral grains and coarse-size silvery mica flakes; dark yellowish orange (10YR 6/6) grading downward to greenish gray $(5 G Y 5 / 1)$

Sand, fine to very fine, silty, greenish-gray ( $5 G Y 5 / 1)$; contains coarse-

size silvery mica flakes; crumbly Mulinia shells near base

Sand, fine, well-sorted, slightly silty, sparsely shelly; greenish gray

$(5 G Y$ 6/1) grading downward to dark gray $(N 3)$

Sand, fine to coarse, dark-gray $(N 3)$; contains calcareous lumps

$0.5-1.0 \mathrm{~cm}$ in diameter.

\section{UNCONFORMITY}

\section{Goose Creek Limestone}

Sand, medium to coarse, very calcareous, sparsely shelly, mediumgreenish-gray $(5 G 5 / 1)$; contains indurated knobbly concretionary lumps, 0.5-cm-diameter rounded phosphate pebbles at base.

\section{Marks Head Formation}

Sand, fine, silty, variably clayey; sparse shell fragments near basal contact; ranges from olive brown (5Y 3/4) through moderate olive brown (5Y 4/4) (31-32 ft) back through olive brown (5Y 3/4) (32-38 ft) and again through moderate olive brown $(5 Y 4 / 4)(38-40 \mathrm{ft})$ back to olive brown $(5 Y 3 / 4)$

\section{UNCONFORMITY}

\section{Ashley Formation, Runnymede Marl Member}

Calcarenite, fine, silty, moderate-olive-brown ( $5 Y 4 / 4)$; quartz and phosphate sand abundant in basal $3 \mathrm{ft}$

Base of Wando Formation, upper member:

Base of Goose Creek Limestone:

Base of Marks Head Formation:

$-8 \mathrm{ft}$ below sea level

$-14 \mathrm{ft}$ below sea level

$-43 \mathrm{ft}$ below sea level

\section{Bottomed in Ashley Formation, Runnymede Marl Member}


AR-4: $3.6 \mathrm{mi}$ west of eastern quadrangle border, $3.75 \mathrm{mi}$ south of northern quadrangle border, in central 1/9th of the quadrangle (latitude $32.6957^{\circ}$ N., longitude $80.3121^{\circ} \mathrm{W}$.). Surface elevation $10 \mathrm{ft}$.

\section{LITHOLOGY}

DEPTH, IN FEET

\section{Wando Formation, upper member}

Sand, fine, well-sorted, yellowish-brown (10YR 7/2); contains very

fine, heavy-mineral grains .....

Sand, very fine to medium, poorly sorted, clayey, silty, stiff; dark grayish orange (10YR 6/4) and mottled light olive gray $(5 Y 5 / 2)$.

Sand, fine to medium, clayey and silty; light olive gray (5Y 5/2)

grading downward to dark greenish gray $(5 G Y 4 / 1)$

Sand, medium to coarse, subrounded to rounded, silty, dark-yellowish-

orange (10YR 6/6).

Sand, very fine to fine, silty, clayey; fine-size silvery mica flakes moderately abundant; dark greenish gray $(5 G Y 4 / 1)$ and mottled dark yellowish orange (10YR 6/6)

Sand, very fine to fine, clean, thixotropic; contains very fine, dark heavy-mineral grains; light olive gray ( $5 Y 6 / 1)$ grading rapidly downward at $9 \mathrm{ft}$ to very dark olive gray $(5 Y 3 / 1)$

Sand, very fine to coarse but mostly fine to medium, poorly sorted, coarser fraction subrounded to rounded, clean, greenish-gray

(10GY 5/1); grades rapidly downward to.

Sand, fine, well-sorted, thixotropic, medium-olive-gray ( $5 Y$ 5/1)

Sand, fine to coarse, very poorly sorted, medium-olive-gray (5Y 5/1);

rounded quartz granules present

Sand, fine, well-sorted, thixotropic; grades downward in basal $1 \mathrm{ft}$ to medium to coarse, rounded, with phosphate pebbles up to $2.5 \mathrm{~cm}$ in diameter and shell fragments; dark greenish gray $(5 G Y 4 / 1)$.

\section{UNCONFORMITY}

\section{Ashley Formation, Givhans Ferry Member}

Calcarenite, fine, silty, quartzose and phosphatic, moderate-olivebrown $(5 Y 4 / 4)$.

Sand, mostly quartz, fine to medium, moderate-olive-brown (5Y 4/4);

contains rounded phosphate pebbles up to $4 \mathrm{~cm}$ in diameter and fragments of basal bored hard ground

\section{UNCONFORMITY}

\section{Harleyville Formation, Osborn Member}

Calcarenite, no quartz or phosphate, light-olive-brown ( $5 Y 5 / 4)$; this interval contained one burrow from above with shark tooth; dusky yellowish brown $(10 Y R 2 / 2)$ 
Base of Wando Formation, upper member:

Base of Ashley Formation, Givhans Ferry Member:

Bottomed in Harleyville Formation, Osborn Member
-35 ft below sea level

$-41 \mathrm{ft}$ below sea level 
AR-5: $1.65 \mathrm{mi}$ west of eastern quadrangle border, $1.35 \mathrm{mi}$ south of northern quadrangle border, in northeast 1/9th of the quadrangle (latitude $32.7305^{\circ} \mathrm{N}$., longitude $80.2785^{\circ}$ W.). Surface elevation $32 \mathrm{ft}$.

\section{LITHOLOGY}

DEPTH, IN FEET

\section{Wando Formation, lower member}

Sand, fine to medium, clean, humic, slightly micaceous; dusky brown (5YR 2/2) and mottled dark yellowish brown (10YR 4/4), grading downward to dark yellowish brown (10YR 4/4) $0-6$

Sand, fine to medium, clean, humic, moderately micaceous, duskyyellow (5Y 6/4); very fine, dark heavy-mineral grains present

Sand, fine, well-sorted, very micaceous, medium-greenish-gray

(5GY 5/1); very fine, dark heavy-mineral grains present

Sand, fine, silty, medium-greenish-gray ( $5 G Y 5 / 1)$; contains sparse

Mulinia shells

Silt, clayey, dense, sticky, sandy (very fine) with fine to medium sand

lenses scattered within, grayish-green $(5 G 4 / 2)$.

Silt, clayey, dense, sticky, grayish-green (5GY 4/2); contains oyster

fragments

Sand, fine to medium, very silty and soft, dark-greenish-gray $(5 G 4 / 1)$.

Sand, medium to coarse, shell hash abundant; olive gray $(5 Y 3 / 2)$

grading downward to moderate olive gray $(5 Y 4 / 2)$; sharp basal contact $40-45$

\section{UNCONFORMITY}

\section{Marks Head Formation}

Sand, fine, well-sorted, slightly clayey and silty, dense, finely micaceous, olive-brown (5Y3/4)

Sand, fine to medium, olive-brown ( $5 Y 3 / 4)$; contains broken oyster fragments; sharp contact with bed below $54-55$

UNCONFORMITY

\section{Ashley Formation, Givhans Ferry Member}

Calcarenite, fine, yellowish-gray $(5 Y 7 / 2)$

Calcarenite, dense, lithified, yellowish-gray ( $5 Y 7 / 2)$; very slow drilling

Calcarenite, quartzose and phosphatic, moderate-olive-brown (5Y 4/4);

fine-size foraminiferal tests abundant.

Base of Wando Formation, lower member:

Base of Marks Head Formation:

\section{Bottomed in Ashley Formation, Givhans Ferry Member}


AR-6: 3.45 mi east of western quadrangle border, $1.75 \mathrm{mi}$ south of northern quadrangle border, in north-central $1 / 9$ th of the quadrangle (latitude $32.7241^{\circ} \mathrm{N}$., longitude $80.3157^{\circ} \mathrm{W}$.). Surface elevation $37 \mathrm{ft}$.

\section{LITHOLOGY}

DEPTH, IN FEET

\section{Wando Formation, lower member}

Sand, fine, well-sorted, clean; grayish orange (10YR 7/4) and mottled yellowish gray $(5 Y 7 / 2)$

Sand, fine, well-sorted, silty; very pale orange $(10 Y R$ 8/2) grading rapidly downward to dusky brown $(5 Y R 2 / 2)$.

Sand, fine to medium, silty, thixotropic, very-dark-yellowish-brown (10YR 3/4); contains scattered rounded coarse grains

Sand, fine, silty, soft, very micaceous; light olive brown (5Y 5/6) grading downward to very light olive gray $(5 Y 6 / 2)$.

Sand, fine, silty, soft, very micaceous, dark-greenish-gray (5GY 4/1); very fine, dark heavy-mineral grains present.

Silt, clayey, sandy (very fine), sticky, grayish-green ( $5 G 5 / 2)$; contains scattered Mulinia shells

Sand, fine to medium grading downward to medium to coarse, silty, soft, dark-greenish-gray $(5 G Y 4 / 1)$

Silt, clayey, dense, dark-greenish-gray (5GY 4/1)

Sand, medium to coarse grading downward to coarse to very coarse with scattered subrounded to rounded quartz granules, silty, soft, darkgreenish-gray (5GY 4/1); shelly in basal $2 \mathrm{ft}$; sharp basal contact

\section{UNCONFORMITY}

\section{Marks Head Formation}

Sand, fine, well-sorted, silty, dense; olive brown (5Y 3/6) grading downward through olive brown (5Y 3/4) to grayish olive (10Y3/4)

\section{Ashley Formation, Runnymede Marl Member}

Calcarenite, fine, light-olive-brown ( $5 Y 5 / 4)$; foraminifera tests

Base of Wando Formation, lower member:

Base of Marks Head Formation:

\section{Bottomed in Ashley Formation, Runnymede Marl Member}


AR-7: $1.3 \mathrm{mi}$ east of western quadrangle border, $1.6 \mathrm{mi}$ south of northern quadrangle border, in northwest 1/9th of the quadrangle (latitude $32.7268^{\circ}$ N., longitude $80.3522^{\circ} \mathrm{W}$.). Surface elevation $42 \mathrm{ft}$.

\section{LITHOLOGY}

DEPTH, IN FEET

\section{Ten Mile Hill Formation}

Sand, fine, well-sorted, clean; scattered very fine, dark heavy-mineral grains present; very pale brown (5YR 6/2) grading downward to dark yellowish orange (10YR 6/6)

Sand, fine, well-sorted, clean, thixotropic; very fine, dark heavymineral grains more abundant than above; grayish yellow (5Y 7/4) grading downward through grayish pink $(5 R 8 / 2)$, pale orange $(10 Y R 7 / 2)(11-14 \mathrm{ft})$, and pale brown $(5 Y R 5 / 2)(14-16 \mathrm{ft})$ to very light olive gray $(5 Y 6 / 2)$.

Sand, fine, well-sorted, clean, micaceous; very fine, dark heavy-mineral grains present; silt lenses present at $36 \mathrm{ft}, 40 \mathrm{ft}$, and $43 \mathrm{ft}$; light olive gray $(5 Y 6 / 2)$ grading downward by $58 \mathrm{ft}$ to medium olive gray $(5 Y 5 / 1)$

Silt, clayey, stiff, medium-greenish-gray ( $5 G Y 5 / 1)$; contains sparse fine-size mica.

Sand, fine to medium grading downward to medium to coarse, medium-greenish-gray (5GY 5/1); scattered lumps of Ashley lithology up to $1 \mathrm{~cm}$ in diameter present near base and rounded pebbles of black $(N 1)$ phosphate up to $8 \mathrm{~cm}$ in diameter.

\section{UNCONFORMITY}

\section{Marks Head Formation}

Sand, fine, clayey; contains scattered medium grains of quartz and coarse grains of phosphate; dark olive brown $(5 Y 3 / 6)$ grading rapidly downward to moderate olive brown $(5 Y 4 / 4)$

\section{UNCONFORMITY}

\section{Ashley Formation, Runnymede Marl Member}

Hard bed; very tough to drill through; no recovery but probably

lithified Ashley

Calcarenite, fine, slightly quartzose and phosphatic, moderate-olive-

Base of Ten Mile Hill Formation:

$-\mathbf{3 4} \mathrm{ft}$ below sea level Base of Marks Head Formation:

\section{Bottomed in Ashley Formation, Runnymede Marl Member}


AR-8: $\quad 3.25 \mathrm{mi}$ west of eastern quadrangle border, $3.9 \mathrm{mi}$ south of northern quadrangle border, in central 1/9th of the quadrangle (latitude $32.6933^{\circ}$ N., longitude $80.3061^{\circ}$ W.). Surface elevation $7 \mathrm{ft}$.

\section{LITHOLOGY}

DEPTH, IN FEET

\section{Silver Bluff beds}

Sand, very fine to fine, slightly silty; yellowish brown $(10 Y R 5 / 2)$ and mottled dark yellowish orange $(10 Y R 6 / 6)$ grading downward to yellowish gray $(5 Y 7 / 2)$ and mottled dark yellowish orange $(10 Y R 6 / 6)$

Sand, very fine to fine, clayey, dense; yellowish gray $(5 Y 7 / 2)$ and mottled dark yellowish orange (10YR 6/6)

Sand, fine, silty, yellowish-gray ( $5 Y 7 / 2)$; scattered coarse to very coarse, subrounded to rounded grains.

\section{UNCONFORMITY}

\section{Wando Formation, upper member}

Sand, fine to very coarse, very poorly sorted, silty, soft; yellowish orange $(10 Y R 7 / 6)$ grading rapidly downward to medium greenish gray $(5 G Y 5 / 1)$

Sand, fine to medium with scattered rounded coarse grains, silty, medium-light-gray $(N 6)$; very fine to fine, dark heavy-mineral grains abundant

Sand, fine to medium, silty, slightly micaceous, moderate-olive-gray (5Y 4/2); grades downward to.

Sand, medium to coarse, silty, slightly micaceous, moderate-olive-gray (5Y 4/2); grades downward to.

Sand, medium to coarse, silty, moderate-olive-gray (5Y 4/2); contains abundant quartz and phosphate pebbles up to $4 \mathrm{~cm}$ in diameter.....

\section{UNCONFORMITY}

\section{Ashley Formation, Runnymede Marl Member}

Calcarenite, fine; composed mostly of foraminifera tests; moderate olive brown (5Y 4/4) grading downward through moderate olive gray $(5 Y 4 / 2)$ and then back by $55 \mathrm{ft}$ to moderate olive brown $(5 Y 4 / 4)$

Base of Silver Bluff beds:

Base of Wando Formation, upper member:

\section{Bottomed in Ashley Formation, Runnymede Marl Member}


AR-9: $1.6 \mathrm{mi}$ east of western quadrangle border, $1.9 \mathrm{mi}$ north of southern quadrangle border, in southwest 1/9th of the quadrangle (latitude $32.6531^{\circ} \mathrm{N}$., longitude $80.3474^{\circ} \mathrm{W}$.). Surface elevation $9 \mathrm{ft}$.

\section{LITHOLOGY}

DEPTH, IN FEET

\section{Silver Bluff beds}

Sand, fine, well-sorted; no color recorded.

Sand, fine to coarse, coarser fraction subangular to subrounded, silty, clayey, stiff; no color recorded.

UNCONFORMITY-

Wando Formation, upper member

Sand, fine, well-sorted, silty, thixotropic; very fine to fine, dark heavymineral grains abundant; no color recorded

Sand, fine, well-sorted, siltier than above, slightly micaceous, thixotropic; a few thin light gray $(N 7)$ clay laminae present; dark yellowish orange (10YR 6/6) grading downward by $25 \mathrm{ft}$ to medium dark gray $(N 4)$ and dark gray $(N 3)$...... $10-33.5$

Clay, silty, greasy, sticky, micaceous, sparsely shelly, dark-gray $(N 3)$....... 33.5-36

Sand, medium to coarse; contains abundant phosphate granules and pebbles up to $2 \mathrm{~cm}$ in diameter and scattered shell fragments; medium dark gray $(N 4)$ with specks of dark yellowish brown $(10 Y R 4 / 2)$. $36-38$

\section{UNCONFORMITY}

\section{Harleyville Formation, Osborn Member}

Calcarenite, fine, well-sorted, silty; mostly composed of foraminiferal tests; scattered grains of glauconite visible; phosphate sand and shell fragments abundant immediately above sharp basal contact; light olive gray $(5 G Y 6 / 1)$ grading downward through light olive gray $(5 Y 5 / 2)$ $(40-45 \mathrm{ft})$ to pale olive $(10 Y 6 / 2)$ $38-52$

-UNCONFORMITY

\section{Parkers Ferry Formation}

Calcilutite, silty, dense and tough, sticky, greenish-olive (10Y 6/4);

Base of Silver Bluff beds:

Base of Wando Formation, upper member: Base of Harleyville Formation, Osborn Member:

\section{Bottomed in Parkers Ferry Formation}




\section{Bennetts Point Quadrangle}

BP-1: $0.7 \mathrm{mi}$ west of eastern quadrangle border, $1.55 \mathrm{mi}$ south of northern quadrangle border, in northeastern 1/9th of the quadrangle (latitude $32.6027^{\circ}$ N., longitude $80.3873^{\circ} \mathrm{W}$.). Surface elevation $7 \mathrm{ft}$.

\section{LITHOLOGY}

DEPTH, IN FEET

Fill material consisting of sand, mud, and concrete $0-1$

\section{UNCONFORMITY}

\section{Silver Bluff beds}

Sand, fine to medium, silty; contains a few scattered coarse grains; grading downward to sand, very fine to fine, very silty, clayey; dark yellowish orange (10YR 6/6) and mottled light olive gray (5Y 6/1) and reddish brown (10R 3/6); grades rapidly downward to.

Silt, sandy (very fine), clayey, micaceous; light olive gray (5Y 6/1) grading downward to greenish gray $(5 G 6 / 1)$ and mottled dark yellowish orange $(10 Y R 6 / 6)$

\section{UNCONFORMITY}

\section{Wando Formation, upper member}

Sand, fine grading downward to bimodal fine to medium, medium fraction rounded, silty; yellowish gray $(5 Y 7 / 2)$ grading downward to grayish yellow $(5 Y 7 / 4)$

Sand, mostly fine, dusky-yellow ( $5 Y 6 / 4)$; very fine, dark heavymineral grains and sparse shell fragments present; grades downward to

Sand, fine to medium, minor coarse fraction, clean, light-olive-gray (5Y 5/2); oyster and other shell hash scattered within; grades downward to.

Sand, medium to very coarse, clean, medium-dark-gray $(N 4)$

\section{Marks Head Formation}

Sand, fine, silty and clayey, finely micaceous; sparse phosphate sand present; moderate olive brown (5Y 4/4) (40-42 ft) grading downward to olive brown $(5 Y 3 / 4)(42-56 \mathrm{ft})$ and then to grayish olive $(10 Y 4 / 2)$.

Sand, fine to medium, grayish-olive (10Y 3/2); contains subangular phosphate pebbles up to $2.5 \mathrm{~cm}$ in diameter.

\section{Ashley Formation, Givhans Ferry Member}

Calcarenite, fine; contains quartz and phosphate sand and large foraminifera tests; olive brown ( $5 Y 3 / 4)$ grading downward to moderate olive brown $(5 Y 4 / 4)$

Calcarenite, medium to very coarse, rounded, moderate-olive-brown (5Y 4/4); phosphate and glauconite sand abundant; large foraminifera tests present 
Ashley Formation, Runnymede Marl Member

Calcarenite, fine to medium, moderate-olive-brown (5Y 4/4); phosphate

sand abundant; sparse black $(N 1)$ 2-cm-diameter phosphate pebbles

along basal contact.

$86-100$

-UNCONFORMITY

Harleyville Formation, Osborn Member

Calcarenite, fine, light-olive-brown (5Y 5/4); small foraminifera tests

abundant; sharp contact with unit below, burrows penetrate unit below

$100-107$

UNCONFORMITY

\section{Parkers Ferry Formation}

Calcisiltite, stiff, dense, medium-greenish-gray ( $5 G Y 5 / 1)$; contains rare

echinoid spines

$107-110$

Base of Silver Bluff beds:

Base of Wando Formation, upper member:

Base of Marks Head Formation:

Base of Ashley Formation, Givhans Ferry Member:

Base of Ashley Formation, Runnymede Marl Member:

Base of Harleyville Formation, Osborn Member:

Bottomed in Parkers Ferry Formation
$-1 \mathrm{ft}$ above sea level

$-33 \mathrm{ft}$ below sea level

$-64 \mathrm{ft}$ below sea level

$-79 \mathrm{ft}$ below sea level

$-93 \mathrm{ft}$ below sea level

$-100 \mathrm{ft}$ below sea level 
BP-2: $2.65 \mathrm{mi}$ east of western quadrangle border, $4.05 \mathrm{mi}$ north of southern quadrangle border, in central 1/9th of the quadrangle (latitude $32.5588^{\circ}$ N., longitude $80.4540^{\circ}$ W.). Surface elevation $7 \mathrm{ft}$.

\section{LITHOLOGY}

DEPTH, IN FEET

\section{Silver Bluff beds}

Sand, fine, well-sorted, clayey and silty, micaceous; contains very sparse very fine, dark heavy-mineral grains; very pale orange $(10 Y R$ 8/2) grading downward through brownish yellowish orange $(7.5 Y R$ 6/6) and mottled pale grayish yellow $(10 Y 8 / 2)(1-6 \mathrm{ft})$ to dark yellowish orange $(10 Y R$ 6/6) and mottled pale grayish yellow $(10 Y 8 / 2)$

Sand, fine to medium, clayey and silty, micaceous; dark yellowish orange $(10 Y R 6 / 6)$ and mottled pale grayish yellow $(10 Y 8 / 2)$

Sand, fine to medium, clayey and silty, micaceous; contains laminae of greasy clay; grayish orange (10YR 7/4) grading downward quickly to medium dark gray $(N 4.5)$

\section{UNCONFORMITY}

\section{Wando Formation, upper member}

Sand, fine to medium; contains scattered phosphate grains and granules; shell fragments abundant; medium light gray $(N 6)$; grades downward to

Sand, medium to very coarse, subangular to subrounded, medium-lightgray $(N 6)$; phosphate sand abundant and one rounded black $(N 1)$ phosphate pebble $2 \mathrm{~cm}$ in diameter; very shelly, including well preserved Oliva, Polinices, oyster fragments, Mulinia hash

Sand, fine to medium, medium-light-gray $(N 6)$; phosphate sand and shell fragments abundant; sharp basal contact.....

UNCONFORMITY

\section{Marks Head Formation}

Sand, fine, very clayey, dense, finely micaceous, grayish-olive (10Y 4/2); grades downward to

Sand, fine, clayey and silty, finely micaceous, olive-gray (5Y 3/2);

grades downward to.

Sand, fine, very clayey, dense, finely micaceous, moderate-olive-gray

$(5 Y 4 / 2)$

Base of Silver Bluff beds:

Base of Wando Formation, upper member:

\section{Bottomed in Marks Head Formation}


BP-3: $1.45 \mathrm{mi}$ east of western quadrangle border, $2.1 \mathrm{mi}$ south of northern quadrangle border, in northwestern $1 / 9$ th of the quadrangle (latitude $32.5941^{\circ} \mathrm{N}$. longitude $80.4749^{\circ} \mathrm{W}$.). Surface elevation $7 \mathrm{ft}$.

\section{LITHOLOGY}

DEPTH, IN FEET

\section{Silver Bluff beds}

Sand, very fine, well-sorted; very fine, dark heavy-mineral grains present; dark yellowish brown (10YR 4/2) grading rapidly downward to grayish yellow $(5 Y 7 / 4)$. $0-1$

Sand, very fine, clayey and silty, finely micaceous; orange (10YR 5/6) and mottled yellowish gray $(5 Y 7 / 2)$.

Clay, sandy (very fine), medium-greenish-gray $(5 G 5 / 1)$.

Sand, fine to very coarse, very poorly sorted, coarser fraction rounded, grayish-yellow $(5 Y 7 / 4)$

\section{UNCONFORMITY}

\section{Wando Formation, upper member}

Sand, fine, silty and clayey, finely micaceous; dark yellowish orange $(10 Y R$ 6/6) and mottled grayish yellow (5Y 7/4)

Sand, fine to medium, silty, thixotropic; grayish yellow (5Y 7/4) grading downward by $18 \mathrm{ft}$ to moderate olive gray $(5 Y 5 / 1)$; grades downward to

Sand, fine, silty, thixotropic, moderate-olive-gray ( $5 Y 5 / 1)$ $33-51$

Sand, fine to medium, thixotropic, medium-greenish-gray (5GY 5/1);

Mulinia shells abundant; oyster shell fragments present near base ..... $51-61$ -UNCONFORMITY

\section{Marks Head Formation}

Sand, fine to medium, poorly sorted, rounded, much denser than above, olive-brown (5Y3/4)

\section{-UNCONFORMITY}

\section{Ashley Formation, Givhans Ferry Member}

Calcarenite, fine, quartzose and phosphatic, light-olive-brown (5Y 5/4); semi-indurated in upper $1 \mathrm{ft}$; sparse shells in basal $2 \mathrm{ft}$.

\section{Ashley Formation, Runnymede Marl Member}

Calcarenite, fine, clayey and silty, light-olive-brown (5Y 5/4); sand fraction mostly composed of foraminifera tests.

Calcarenite, fine to medium, quartzose and phosphatic, light-olivebrown (5Y 5/4); black ( $N 1)$ phosphate lumps present up to $8 \mathrm{~cm}$ in diameter 


\section{Harleyville Formation, Osborn Member}

Calcarenite, fine, silty, grainy, increasingly clayey downward; dark yellowish gray (5Y 6/2) grading downward through pale olive $(10 Y 6 / 2)$ and greenish gray $(5 G Y 6 / 1)$ to pale grayish olive $(10 Y 5 / 2)$.... $97-104$

Calcarenite, very fine, very clayey and silty, pale-grayish-olive (10Y 5/2); sand fraction mostly composed of foraminifera tests

Base of Silver Bluff beds:

Base of Wando Formation, upper member:

Base of Marks Head Formation:

Base of Ashley Formation, Givhans Ferry Member:

Base of Ashley Formation, Runnymede Marl Member:

$-1 \mathrm{ft}$ below sea level $-54 \mathrm{ft}$ below sea level $-63 \mathrm{ft}$ below sea level

$-71 \mathrm{ft}$ below sea level

Bottomed in Harleyville Formation, Osborn Member 


\section{Cottageville Quadrangle}

CV-1: 2.2 mi west of eastern quadrangle border, $3.65 \mathrm{mi}$ south of northern quadrangle border, in east-central 1/9th of the quadrangle (latitude $32.9469^{\circ} \mathrm{N}$., longitude $80.3955^{\circ} \mathrm{W}$.). Surface elevation $27 \mathrm{ft}$.

\section{LITHOLOGY}

DEPTH, IN FEET

\section{Wando Formation, upper member}

Sand, fine to very coarse, very poorly sorted, clean, dark-yellowishorange $(10 Y R 6 / 6)$.

Sand, fine to coarse, poorly sorted, silty in basal $2 \mathrm{ft}$; orange $(10 Y R 5 / 6)$ grading downward through pale grayish orange $(10 Y R$ 8/2) $(2-4 \mathrm{ft})$ to very pale yellowish brown (10YR 7/2)

Sand, medium to very coarse, clean, silty in basal $2 \mathrm{ft}$; very pale yellowish brown (10YR 7/2) grading downward near base to olive gray $(5 Y 3 / 2)$

\section{UNCONFORMITY}

\section{Ashley Formation, Givhans Ferry Member}

Calcarenite, fine, silty; glauconite and phosphate increasingly abundant downward; phosphate pebbles and shell molds present in basal $5 \mathrm{ft}$; moderate olive brown (5Y 4/4) grading downward to olive (10Y 5/2).

\section{Ashley Formation, Runnymede Marl Member}

Calcarenite, fine, light-olive-brown (5Y 5/4); upper $1 \mathrm{ft}$ burrowed from above; very hard at base

\section{UNCONFORMITY}

\section{Harleyville Formation, Osborn Member}

Calcarenite, fine; very pale olive (10Y7/2) grading downward to light olive (10Y 5/2); very tough drilling and slow penetration $46-51$

Base of Wando Formation, upper member:

Base of Ashley Formation, Givhans Ferry Member:

Base of Ashley Formation, Runnymede Marl Member:

\section{Bottomed in Harleyville Formation, Osborn Member}

$+10 \mathrm{ft}$ above sea level $-4 \mathrm{ft}$ below sea level $-19 \mathrm{ft}$ below sea level 
CV-2: $0.6 \mathrm{mi}$ east of western quadrangle border, $3.65 \mathrm{mi}$ north of southern quadrangle border, in west-central $1 / 9$ th of the quadrangle (latitude $32.9281^{\circ} \mathrm{N}$., longitude $80.4899^{\circ}$ W.). Surface elevation $43 \mathrm{ft}$.

\section{LITHOLOGY}

DEPTH, IN FEET

\section{Ladson Formation}

Sand, mostly medium but ranging up to very coarse, clean; dark yellowish brown (10YR 4/4) grading downward through grayish orange

$(10 Y R$ 6/4) and grayish orange (10YR 7/4) to yellowish brown

$(5 Y R$ 4/6) with streaks of light gray $(N 7)$

Sand, mostly medium but ranging up to very coarse, clean, grayish-

orange (10YR 6/4); grades rapidly downward to

Sand, medium to very coarse grading downward to coarse to very

coarse, silty, soft, wet, pale-orange (10YR 8/2)

\section{UNCONFORMITY}

\section{Parachucla Shale equivalent}

Sand, very fine to fine, silty, slightly clayey, sparsely micaceous, olivegray $(5 Y 4 / 2)$; sparse foraminifera tests in basal $1 \mathrm{ft}$. $16-26$

Sand, very fine to fine, silty, clayey, micaceous, olive-brown (5Y 3/4) 26-32

Sand, mostly fine but with a minor fraction of medium to coarse, phosphatic, light-olive-gray ( $5 Y 5 / 2)$; lumps of Ashley lithology present from bed below

\section{UNCONFORMITY}

\section{Ashley Formation, Runnymede Marl Member}

Calcarenite, fine, slightly quartzose; mostly consists of sand-size foraminifera tests; shell fragments present; pale olive gray $(5 Y 6 / 2)$ grading downward to light olive brown (5Y 5/4).

Sand, medium to coarse, calcareous, very quartzose; glauconite and phosphate sand abundant; phosphate pebbles up to $1 \mathrm{~cm}$ in diameter common in basal $2 \mathrm{ft}$; light olive brown (5Y 5/4) grading downward to olive brown $(5 Y 3 / 4)$

\section{UNCONFORMITY}

\section{Harleyville Formation, Osborn Member}

Calcarenite, medium to very coarse, pale-olive (10Y 6/2); composed mostly of shell fragments; top $1 \mathrm{ft}$ very tough then moderately stiff below that; sample at $70 \mathrm{ft}$ yielded NP 21 nannofossils $61-71$

Base of Ladson Formation:

Base of Parachucla Shale:

Base of Ashley Formation, Runnymede Marl Member:

$+27 \mathrm{ft}$ above sea level $+7 \mathrm{ft}$ above sea level $-18 \mathrm{ft}$ below sea level

\section{Bottomed in Harleyville Formation, Osborn Member}


CV-3: $3.1 \mathrm{mi}$ west of eastern quadrangle border, $1.85 \mathrm{mi}$ south of northern quadrangle border, in north-central $1 / 9$ th of the quadrangle (latitude $32.9733^{\circ} \mathrm{N}$., longitude $80.4284^{\circ}$ W.). Surface elevation $32 \mathrm{ft}$.

\section{LITHOLOGY}

DEPTH, IN FEET

\section{Edisto River floodplain sediment}

Sand, fine to very coarse, very poorly sorted, subrounded to subangular; very dusky red (10R 2/2) grading downward to dark grayish orange (10YR 6/4) $0-1$

Sand, fine to very coarse, very poorly sorted, subrounded to subangular, loose; very pale orange $(10 Y R 8 / 2)$ grading downward to pale yellowish brown (10YR 6/2); easy drilling..... $1-10$

Clay, silty, soft, greasy, moderate-olive-gray (5Y 4/2) $10-12$

Sand, fine to coarse, poorly sorted, very silty, slightly clayey, grading downward to medium to very coarse with quartz granules; subangular quartz pebbles up to $1 \mathrm{~cm}$ in diameter at base; moderate olive gray $(5 Y 4 / 2)$

UNCONFORMITY

\section{Ashley Formation, Runnymede Marl Member}

Calcarenite, fine, quartzose and phosphatic, moderate-olive-brown $(5 Y 4 / 4)$

Sand, fine to medium, very phosphatic and calcareous, moderate-olivebrown (5Y 4/4); rounded phosphate pebbles and calcareous lumps in basal $1 \mathrm{ft}$

\section{UNCONFORMITY}

\section{Harleyville Formation, Osborn Member}

Calcarenite, fine, soft, medium-olive (10Y 5/5); foraminifera tests abundant

\section{Bottomed in Harleyville Formation, Osborn Member}


CV-4: $1.2 \mathrm{mi}$ west of eastern quadrangle border, $1.45 \mathrm{mi}$ south of northern quadrangle border, in northeast 1/9th of the quadrangle (latitude $32.9794^{\circ}$ N., longitude $80.3954^{\circ}$ W.). Surface elevation $45 \mathrm{ft}$.

\section{LITHOLOGY}

DEPTH, IN FEET

\section{Ladson Formation}

Sand, mostly fine but ranges up to very coarse, poorly sorted, silty; light yellowish brown (10YR 6/4) and mottled dark yellowish brown $(10 Y R 4 / 2)$

Silt, clayey, sandy (very fine), finely micaceous, sticky, yellowishorange (7.5YR 6/6); grades downward to.

Sand, mostly medium to coarse but ranges from very fine to coarse, poorly sorted, silty and slightly clayey, yellowish-gray (5Y7/2); grades downward to

Sand, very fine to very coarse, very poorly sorted, silty and very clayey, light-olive-brown (5Y 5/4).

-UNCONFORMITY

\section{Goose Creek Limestone}

Calcarenite, mostly medium, silty, slightly phosphatic, pale-yellowishgray (5Y9/1); grades downward to fine to coarse in basal $1 \mathrm{ft}$ with rounded to subangular calcite-cemented lumps and rounded black $\left(\begin{array}{l}N 1) \\ 1)\end{array}\right.$ phosphate pebbles.

\section{UNCONFORMITY}

\section{Ashley Formation, Givhans Ferry Member}

Calcarenite, fine, quartzose, dark-yellowish-gray ( $5 Y$ 6/2); grades downward to $13-16$

Sand, fine, very calcareous, dark-yellowish-gray (5Y 6/2) $16-25$

Calcarenite, fine, quartzose, more clayey and denser than above, lightolive-brown (5Y 5/4); grades downward to

Calcarenite, fine, quartzose, phosphatic, glauconitic, light-olive-brown

(5Y 5/4); grades downward to.

Sand, fine to medium, very calcareous, light-olive-brown ( $5 Y 5 / 4)$;

basal $1 \mathrm{ft}$ contains subangular to subrounded phosphate lumps up to

$2 \mathrm{~cm}$ in diameter. $45-48$

-UNCONFORMITY-

\section{Ashley Formation, Runnymede Marl Member}

Calcarenite, fine, sparsely quartzose, light-olive-brown (5Y 5/4).

Base of Ladson Formation:

Base of Goose Creek Limestone:

Base of Ashley Formation, Givhans Ferry Member:
$+34 \mathrm{ft}$ above sea level $+32 \mathrm{ft}$ above sea level $-\mathbf{3} \mathrm{ft}$ below sea level

\section{Bottomed in Ashley Formation, Runnymede Marl Member}


CV-5: $2.7 \mathrm{mi}$ west of eastern quadrangle border, $3.5 \mathrm{mi}$ north of southern quadrangle border, in central 1/9th of the quadrangle (latitude $32.9255^{\circ}$ N., longitude $80.4216^{\circ} \mathrm{W}$.). Surface elevation $29 \mathrm{ft}$.

\section{LITHOLOGY}

DEPTH, IN FEET

\section{Edisto River floodplain sediment}

Sand, fine to coarse, poorly sorted, soft, humic; dusky brown (5YR 2/2)

grading downward to dark yellowish brown (10YR 4/2)

Sand, fine to coarse, poorly sorted, feldspathic, soft, humic; very pale yellowish brown (10YR 7/2) grading downward by $5 \mathrm{ft}$ to light grayish orange (10YR 8/4); grades downward to

Sand, medium to very coarse, poorly sorted, feldspathic, soft, humic, olive-brown $(5 Y 3 / 4)$

\section{UNCONFORMITY}

\section{Ashley Formation, Runnymede Marl Member}

Calcarenite, very fine to fine, slightly phosphatic and quartzose; mostly composed of foraminifera tests; phosphate pebbles and calcitecemented lumps up to $4 \mathrm{~cm}$ in diameter present in basal $1 \mathrm{ft}$; light olive brown $(5 Y 5 / 4)$ grading downward to moderate olive brown $(5 Y 4 / 4)$

Calcarenite, fine, light-olive-brown (5Y 5/4); mostly composed of foraminifera tests; sparse shell fragments present; hard zone at base

\section{Harleyville Formation, Osborn Member}

Calcarenite, fine, silty, soft, pale-olive (10Y 5/2); mostly composed of foraminifera tests

Base of Edisto River floodplain sediment:

Base of Ashley Formation, Runnymede Marl Member:

$+14 \mathrm{ft}$ above sea level $-2 \mathrm{ft}$ below sea level

\section{Bottomed in Harleyville Formation, Osborn Member}


CV-6: $1.85 \mathrm{mi}$ east of western quadrangle border, $1.55 \mathrm{mi}$ south of northern quadrangle border, in northwest 1/9th of the quadrangle (latitude $32.9783^{\circ}$ N., longitude $80.4680^{\circ}$ W.). Surface elevation $52 \mathrm{ft}$.

\section{LITHOLOGY}

DEPTH, IN FEET

\section{Ladson Formation}

Sand, fine to very coarse, very poorly sorted, subangular to subrounded, silty, clayey; grayish brown $(5 Y R 3 / 2)$ grading downward through moderate yellowish brown $(10 Y R 5 / 4)$ and red $(10 R 5 / 6)$ (4-6 ft) to moderate yellowish brown (10YR 5/4)

Sand, fine to very coarse, very poorly sorted, subangular to subrounded, silty, loose; sparse subrounded quartz pebbles in basal $1 \mathrm{ft}$; orange (10YR 5/6) grading downward at about $12 \mathrm{ft}$ to very pale orange $(10 Y R 8 / 2)$

-UNCONFORMITY

\section{Parachucla Shale}

Silt, sandy (very fine), clayey, dark-grayish-orange (10YR 6/4).

Silt, sandy (very fine), clayey, olive-brown (5Y3/4); rounded phosphate granules; sparse very coarse quartz grains; oyster fragments in basal 6 in.

\section{UNCONFORMITY}

\section{Ashley Formation, Runnymede Marl Member}

Calcarenite, very fine to fine, light-olive-brown ( $5 Y 5 / 4)$; mostly foraminifera tests; quartzose and phosphatic toward base; subangular to subrounded phosphate pebbles up to $3 \mathrm{~cm}$ in diameter in basal $1 \mathrm{ft}$.

\section{Harleyville Formation, Osborn Member}

Calcarenite, very fine to fine, pale-olive-gray ( $5 Y 6 / 2)$; most fell off stems

Base of Ladson Formation:

Base of Parachucla Shale:

Base of Ashley Formation, Runnymede Marl Member:
$+35 \mathrm{ft}$ above sea level

$+29 \mathrm{ft}$ above sea level

$-4 \mathrm{ft}$ below sea level

\section{Bottomed in Harleyville Formation, Osborn Member}


CV-7: $0.15 \mathrm{mi}$ east of western quadrangle border, $0.15 \mathrm{mi}$ south of northern quadrangle border, in northwest 1/9th of the quadrangle (latitude $32.9977^{\circ}$ N., longitude $80.4980^{\circ}$ W.). Surface elevation $72 \mathrm{ft}$.

\section{LITHOLOGY}

DEPTH, IN FEET

\section{Penholoway formation}

Sand, fine, well-sorted, increasingly clayey downward; plinthite lumps present; grayish brown $(5 Y R 3 / 2)$ grading downward through pale yellowish brown (10YR 6/4) and dark yellowish orange (10YR 6/6) to dark yellowish brown (10YR 4/6); grades rapidly downward to

Clay, sandy (very fine), silty, stiff and dense, increasingly sandy downward; yellowish gray $(5 Y 7 / 2)$ and mottled reddish orange $(10 R 5 / 6)$ and dark red $(5 R 3 / 6)$; grades rapidly downward to

Sand, fine to medium, poorly sorted, very silty, soft, dark-orange $(5 Y R 3 / 6)$ $12-14$

Clay, silty, sandy, stiff, yellowish-gray (5Y 7/2) $14-16$

Sand, fine to medium, poorly sorted, very silty, soft, dark-orange (5YR 3/6)......

Clay, silty, sandy, stiff, yellowish-gray (5Y 7/2)

Sand, fine to medium, poorly sorted, very silty, soft, dark-grayishorange $(10 Y R 6 / 4)$.

Sand, dominantly fine to medium but with a secondary bimodal coarse to very coarse fraction, very soft, dark-grayish-orange (10YR 6/4); sparse very fine to fine, dark heavy-mineral grains present

Sand, very fine to fine, well-sorted, very silty, soft, thixotropic, palegrayish-orange (10YR 8/4); sparse very fine to fine, dark heavy-mineral grains present.

Sand, fine to medium, silty, olive (10Y 3/4); small phosphate discoid $2 \mathrm{~cm}$ in length on basal contact.

-UNCONFORMITY

\section{Parachucla Shale}

Sand, fine, well-sorted, silty, clayey, very stiff and dense, dark-olivegray $(5 Y 2 / 2)$; very hard to get off stems

\section{Base of Penholoway formation:}

\section{Bottomed in Parachucla Shale}




\section{Edisto Beach Quadrangle}

EB-1: $2.3 \mathrm{mi}$ east of western quadrangle border, $1.5 \mathrm{mi}$ south of northern quadrangle border, in northwest 1/9th of the quadrangle (latitude $32.4785^{\circ} \mathrm{N}$., longitude $80.3356^{\circ} \mathrm{W}$.). Surface elevation $7 \mathrm{ft}$.

\section{LITHOLOGY}

DEPTH, IN FEET

\section{Holocene beach sand}

Sand, fine, well-sorted, clean; very fine, dark heavy-mineral grains abundant; dark yellowish brown (10YR 4/2) grading downward through very light gray $(N 8)$ to greenish gray $(5 G 5 / 1)$.

Sand, fine, well-sorted, clean, loose; shells and shell hash abundant; fine, dark heavy-mineral grains abundant; sparse grains of phosphate and glauconite present up to coarse size; greenish gray $(5 G 5 / 1)$ grading downward through olive gray $(5 Y 4 / 1)$ to dark greenish gray $(5 G Y 4 / 1)$

Shell hash, very-light-gray $(N 8)$

Sand, fine, well-sorted, clean, loose, dark-greenish-gray (5GY 4/1);

shells and shell hash abundant; fine, dark heavy-mineral grains

abundant; sparse grains of phosphate and glauconite up to coarse size......

Sand, fine, well-sorted, humic; color varies from medium light gray

$(N 6)$ to dark gray $(N 3)$

Sand, fine, well-sorted, thixotropic, olive-gray ( $5 Y 5 / 1)$; very fine to

fine, dark heavy-mineral grains abundant.

Sand, fine, clayey and silty, odiferous, greasy, micaceous; light olive gray $(5 Y 6 / 1)$ streaked medium dark gray $(N 4)$ and dark gray $(N 3)$

Sand, medium to very coarse, poorly sorted, olive-gray ( $5 Y 5 / 1)$; shell fragments abundant; fine, dark heavy-mineral grains sparsely present; contains a clast of wood (cedar?) near top.

Sand, fine, silty, medium-dark-gray $(N 4)$; interbedded with clay, silty and sandy (very fine), odiferous, greasy, slightly micaceous, oliveblack (5Y 2/1) and grayish-black (N2)

\section{Wando Formation, middle member}

Shell hash containing calcite-cemented sandy lumps with shell molds; sparse fine, dark heavy-mineral grains present; large bone fragment on basal contact; light gray $(N 7)$ to very light gray $(N 8)$

\section{UNCONFORMITY}

\section{Daniel Island beds}

Clay, silty, stiff, sticky, dark-greenish-gray $(5 G 4 / 1)$ to greenish-black $(5 G 3 / 1)$ 


\section{Marks Head Formation}

Sand, fine, well-sorted, silty, slightly clayey, slightly sticky, sparsely phosphatic; moderate olive brown (5Y 4/4) grading downward to olive gray $(5 Y 3 / 2)$; sharp contact with bed below

Silt, sandy (very fine), waxy, moderately dense and sticky, finely

micaceous, locally calcareous, olive-gray $(5 Y 3 / 2)$. $61-70$

Sand, fine, silty, finely micaceous; olive gray (5Y 3/2) grading downward to moderate olive brown $(5 Y 4 / 4)$

Sand, fine to medium, silty, moderate-olive-brown (5Y 4/4); contains rounded phosphate pebbles up to $5 \mathrm{~cm}$ in diameter

UNCONFORMITY

\section{Harleyville Formation, Osborn Member}

Calcarenite, fine, grayish-yellow ( $5 Y 8 / 4)$; stopped on contact so only a wisp of this unit was recovered at 90

Base of Holocene beach sand:

Base of Wando Formation, middle member:

Base of Daniel Island beds:

Base of Marks Head Formation:

$-42 \mathrm{ft}$ below sea level

$-48 \mathrm{ft}$ below sea level

$-49 \mathrm{ft}$ below sea level

$-83 \mathrm{ft}$ below sea level

\section{Bottomed on Harleyville Formation, Osborn Member}




\section{Edisto Island Quadrangle}

EI-1: $1.35 \mathrm{mi}$ east of western quadrangle border, $0.65 \mathrm{mi}$ south of northern quadrangle border, in northwest 1/9th of the quadrangle (latitude $32.6153^{\circ} \mathrm{N}$., longitude $80.3517^{\circ} \mathrm{W}$.). Surface elevation $7 \mathrm{ft}$.

\section{LITHOLOGY}

DEPTH, IN FEET

\section{Silver Bluff beds}

Sand, fine, well-sorted, silty, slightly clayey; grayish yellow (10Y 7/4), grayish brown (10YR 3/2) and mottled dark yellowish orange $(10 Y R$ 6/6)

Sand, fine grading downward to very fine, increasingly clayey and silty

downward, micaceous in basal $1 \mathrm{ft}$; dark yellowish orange (10YR 6/6)

and yellowish gray $(5 Y 7 / 2)$ grading downward to light olive gray

$(5 Y 6 / 1)$

Sand, fine, well-sorted, silty, dark-yellowish-brown (10YR 4/6); very

fine, dark heavy-mineral grains abundant

Sand, very fine, clayey, silty, light-bluish-gray ( $5 B 7 / 1)$

Silt, sandy (very fine), clayey, greasy, micaceous, medium-bluish-gray

$(5 B 5 / 1)$

Sand, fine, micaceous, medium-bluish-gray ( $5 B$ 5/1); glossy Mulinia

shells abundant; burrows penetrate bed below

\section{UNCONFORMITY}

\section{Wando Formation, middle member}

Silt, clayey, sandy, more dense and stiff than above; interbedded at

1- to 2-ft intervals with sand, very fine to fine, silty and clayey;

medium greenish gray $(5 G 5 / 1)$

Sand, fine to medium, silty, medium-greenish-gray ( $5 G 5 / 1)$; contains subrounded to rounded lumps of knobby phosphate up to $3 \mathrm{~cm}$ in diameter

\section{UNCONFORMITY}

\section{Harleyville Formation, Osborn Member}

Calcarenite, very fine to fine, silty, increasingly clayey downward;

foraminifera tests abundant; grayish yellow $(5 Y 7 / 4)$ grading downward

by $53 \mathrm{ft}$ to light olive brown ( $5 Y 5 / 4)$; grades downward to

Calcilutite, clayey, slightly sandy, stiff, light-olive-brown (5Y 5/4);

hard to remove from auger flights

Base of Silver Bluff beds:

Base of Wando Formation, middle member:

\section{Bottomed in Harleyville Formation, Osborn Member}


EI-2: $3.55 \mathrm{mi}$ west of eastern quadrangle border, $1.4 \mathrm{mi}$ north of southern quadrangle border, in south-central 1/9th of the quadrangle (latitude $32.5204^{\circ}$ N., longitude $80.3104^{\circ}$ W.). Surface elevation $8 \mathrm{ft}$.

\section{LITHOLOGY}

DEPTH, IN FEET

\section{Wando Formation, upper member}

Sand, fine, well-sorted, clean, thixotropic; very fine, dark heavymineral grains abundant below $1 \mathrm{ft}$; dark yellowish brown (10YR 4/2)

grading downward through dark yellowish orange (10YR 6/6) and grayish yellow $(5 Y 7 / 4)(1-6 \mathrm{ft})$, and through olive gray $(5 Y 3 / 2)$

$(6-8 \mathrm{ft})$ to medium greenish gray $(5 G Y 5 / 1)$.

Sand, fine, well-sorted, clean, shelly, grayish-olive (10Y 3/2); very fine,

dark heavy-mineral grains abundant. $11-14$

Sand, fine, well-sorted, slightly silty; interbedded with 3- to 6-in.-thick layers of sand, fine, clayey and silty; grayish olive (10Y 3/2) $14-16$

Silt, clayey, sandy (very fine), medium-greenish-gray ( $5 G Y 5 / 1$ ); worn Rangia shells in basal 6 in. $16-20$

Sand, fine, well-sorted, light-olive-brown (5Y 5/4) $20-21$

\section{UNCONFORMITY}

\section{Wando Formation, middle member}

Sand, fine, silty; interbedded with silt, clayey, sandy (very fine); shells present; light olive brown ( $5 Y 5 / 4)$..... $21-24$

Silt, clayey, sandy (very fine), light-olive-brown (5Y 5/4) 24-33

Sand, fine, silty, slightly clayey, sparsely shelly, light-olive-brown $(5 Y 5 / 4)$

Silt, clayey, sandy, light-olive-brown (5Y 5/4) $43-44$

Sand, fine, silty, slightly clayey, sparsely shelly, light-olive-brown $(5 Y 5 / 4)$

Silt, clayey, sandy (very fine), light-olive-brown (5Y 5/4) $47-51$

Sand, fine, silty, light-olive-brown (5Y 5/4); shell hash and rounded phosphate granules on basal contact. $51-55$ UNCONFORMITY

\section{Marks Head Formation}

Sand, fine, dense, very phosphatic, olive-brown (5Y 3/4); sharp contact with bed below

Sand, fine, clayey, dense, finely micaceous, moderate-olive-brown (5Y 4/4); contains burrows filled with overlying lithology....

\section{UNCONFORMITY}

\section{Harleyville Formation, Osborn Member}

Calcarenite, lithified; auger drill bit spun before being able to penetrate this unit 
Calcarenite, fine, grainy, soft, grayish-yellow (5Y 7/4); sparse fine

phosphate sand present

Calcarenite, fine, quartzose and phosphatic; 1 -in.-thick layer of very

fine quartz sand at base; moderate olive gray $(5 Y 4 / 2)$

\section{Parkers Ferry Formation}

Calcilutite, dense, sticky, grayish-olive (10Y 5/2); contains echinoid spines $72-81$

Base of Wando Formation, upper member:

Base of Wando Formation, middle member:

Base of Marks Head Formation:

Base of Harleyville Formation, Osborn Member
$-13 \mathrm{ft}$ below sea level

$-47 \mathrm{ft}$ below sea level $-51 \mathrm{ft}$ below sea level $-64 \mathrm{ft}$ below sea level

\section{Bottomed in Parkers Ferry Formation}


EI-3: $0.95 \mathrm{mi}$ east of western quadrangle border, $4.45 \mathrm{mi}$ south of northern quadrangle border, in west-central $1 / 9$ th of the quadrangle (latitude $32.5602^{\circ} \mathrm{N}$., longitude $80.3591^{\circ}$ W.). Surface elevation $17 \mathrm{ft}$.

\section{LITHOLOGY}

DEPTH, IN FEET

\section{Wando Formation upper member}

Sand, fine, well-sorted, clean; pseudoplinthite at $4 \mathrm{ft}$; dark yellowish brown (10YR 3/2) grading downward through dark yellowish orange $(10 Y R$ 6/6) and light yellowish brown (10YR 6/4) (1-4 ft) to yellowish orange $(10 Y R 7 / 6)$.

Sand, fine, well-sorted, clean, slightly micaceous, yellowish-gray

(5Y7/2); very fine, dark heavy-mineral grains present.

Silt, clayey, sandy (very fine), medium-bluish-gray ( $5 B 5 / 1)$

Sand, fine, well-sorted, silty, sparsely shelly, grayish-green (5G 6/2);

sparse very fine, dark heavy-mineral grains present; grades downward to

Sand, medium grading downward to medium to coarse, silty, grayishgreen $(5 G 6 / 2)$; very shelly with mostly oysters at top but fauna becoming more diverse downward; sparse rounded coarse phosphate grains near base; sharp contact with bed below.

\section{UNCONFORMITY}

\section{Wando Formation, middle member}

Silt, clayey, sandy (very fine), stiff, grayish-green ( $5 G 6 / 2)$

Sand, fine, silty, shelly, grading downward to sand, medium to coarse; contains abundant shell hash; rounded lumps of Marks Head lithology present in basal $1 \mathrm{ft}$; grayish green $(5 G 6 / 2)$.

\section{UNCONFORMITY}

\section{Marks Head Formation}

Sand, fine, silty, phosphatic; rounded phosphate pebbles and rounded lumps of Ashley lithology up to $3 \mathrm{~cm}$ in diameter present in basal $1 \mathrm{ft}$; olive brown (5Y 3/4) grading downward by $70 \mathrm{ft}$ to dark olive brown $(5 Y 2 / 4)$ $60-73$

\section{UNCONFORMITY}

\section{Ashley Formation, Givhans Ferry Member}

Sand, calcareous and phosphatic; contains granules of phosphate and large foraminifera tests; light olive brown $(5 Y 6 / 6)$ grading downward to moderate olive brown $(5 Y 4 / 4)$

Calcarenite, quartzose and phosphatic, moderate-olive-brown (5Y 4/4);

Base of Wando Formation, upper member:

Base of Wando Formation, middle member:

Base of Marks Head Formation:

\section{Bottomed in Ashley Formation, Givhans Ferry Member}


EI-4: $1.35 \mathrm{mi}$ west of eastern quadrangle border, $1.75 \mathrm{mi}$ north of southern quadrangle border, in southeast 1/9th of the quadrangle (latitude $32.5252^{\circ}$ N., longitude $80.2725^{\circ}$ W.). Surface elevation $7 \mathrm{ft}$.

\section{LITHOLOGY}

DEPTH, IN FEET

\section{Silver Bluff beds}

Sand, fine, well-sorted, clean, thixotropic; very fine, dark heavymineral grains abundant; dark gray $(N 3)$ grading downward through moderate olive brown $(5 Y 4 / 4)(2-4 \mathrm{ft})$, pale yellowish green $(10 G Y 7 / 2)(4-10 \mathrm{ft})$, and grayish olive $(10 Y 4 / 2)(10-14 \mathrm{ft})$ to light olive brown $(5 Y 5 / 6)$

Sand, very fine, silty, clayey, medium-grayish-blue ( $5 P B 4 / 2)$

Shell hash, mostly oyster but also some Mercenaria, fragments slightly rounded, medium-bluish-gray $(5 B 5 / 1)$

\section{-UNCONFORMITY}

\section{Wando Formation, upper member}

Sand, fine, well-sorted, shelly, light-bluish-gray ( $5 B 7 / 1)$; diverse fauna $17-27.5$

Clay, sandy (very fine), silty, sticky, fairly dense, micaceous, mediumgreenish-gray $(5 G 5 / 1)$...

Sand, fine, well-sorted, slightly silty, moderately shelly, greenish-gray $(5 G 6 / 1)$

Clay, sandy (very fine), silty, sticky, fairly dense, micaceous, mediumgreenish-gray $(5 G 5 / 1)$

Sand, fine, well-sorted, slightly silty, moderately shelly, greenish-gray

( $5 G 6 / 1)$; contains $1-2$ percent very fine to fine, dark heavy-mineral grains

Clay, sandy (very fine), silty, sticky, fairly dense, micaceous, mediumgreenish-gray $(5 G 5 / 1)$

Sand, fine, well-sorted, slightly silty, moderately shelly, greenish-gray ( $5 G 6 / 1)$; contains $1-2$ percent very fine to fine, dark heavy-mineral grains

\section{UNCONFORMITY}

\section{Marks Head Formation}

Sand, fine, clayey and silty; interbedded with silt, sandy (very fine), clayey, dense, sticky, cheesy texture, finely micaceous; contains 1-2 percent fine phosphate grains; moderate olive brown (5Y 4/4); grades downward to.

Sand, fine, clean, olive-gray ( $5 Y 3 / 3)$; contains sparse fine phosphate and glauconite grains; sharp contact with bed below

Silt, clayey, sticky, cheesy texture, finely micaceous, moderate-olivebrown $(5 Y 4 / 4)$.

Sand, fine, finely micaceous, dark-grayish-olive-green (5GY 2/2); scattered polished medium quartz grains in basal $4 \mathrm{ft}$. 


\section{Ashley Formation, Runnymede Marl Member}

Calcarenite, fine, phosphatic and glauconitic, moderate-olive-brown

(5Y 4/4); foraminifera tests abundant; grades downward to

Calcarenite, fine, quartzose and phosphatic, grayish-olive (10Y 4/2);

foraminifera tests abundant; rounded phosphate pebbles up to $1 \mathrm{~cm}$

near base; scattered medium grains of quartz in basal $1 \mathrm{ft}$; sharp basal

contact

\section{UNCONFORMITY}

\section{Harleyville Formation, Osborn Member}

Calcarenite, fine, silty, pale-olive (10Y 6/2); composed mostly of

foraminifera tests; loose on stems $86-95$

Base of Silver Bluff beds:

Base of Wando Formation, upper member:

Base of Marks Head Formation:

Base of Ashley Formation, Runnymede Marl Member:

$-10 \mathrm{ft}$ below sea level

$-36 \mathrm{ft}$ below sea level

$-67 \mathrm{ft}$ below sea level

$-79 \mathrm{ft}$ below sea level

\section{Bottomed in Harleyville Formation, Osborn Member}


EI-5: $3.55 \mathrm{mi}$ east of western quadrangle border, $3.95 \mathrm{mi}$ south of northern quadrangle border, in central 1/9th of the quadrangle (latitude $32.5679^{\circ}$ N., longitude $80.3144^{\circ}$ W.). Surface elevation $17 \mathrm{ft}$.

\section{LITHOLOGY}

DEPTH, IN FEET

\section{Wando Formation, upper member}

Sand, fine, well-sorted, clean; dark yellowish orange (10YR 6/6) grading downward through grayish yellow $(5 Y 8 / 4)$ to brownish yellowish orange $(7.5 Y R 6 / 6)$

Sand, fine, well-sorted, clean, increasingly micaceous downward; very

fine to fine, dark heavy-mineral grains abundant; basal $1 \mathrm{ft}$ fine to

coarse, poorly sorted, coarse fraction subangular; pale olive (10Y 6/2)

grading downward through dusky yellow $(5 Y 6 / 4)(14-22.5 \mathrm{ft})$ and

light brown $(5 Y R 5 / 6)(22.5-27 \mathrm{ft})$ to medium gray $(N 5)$.

Silt, clayey, sandy (very fine), olive-gray ( $5 Y 4 / 1)$; at base, 3-in.-thick

peat bed, clayey, micaceous, dusky-brown $(5 Y R 2 / 2)$....

\section{UNCONFORMITY}

\section{Wando Formation, middle member}

Sand, fine, well-sorted, slightly silty, very shelly, medium-bluish-gray $(5 B 6 / 1)$

Sand, fine, well-sorted, medium-gray ( $N 5$ ); very shelly with oyster, Mulinia, and snails abundant; sharp basal contact.....

\section{UNCONFORMITY}

\section{Wando Formation, lower member}

Clay, silty, dense, micaceous, light-bluish-gray ( $5 B 7 / 1)$; contains abundant caliche-like calcareous nodules up to $5 \mathrm{~cm}$ in diameter in upper $0.5 \mathrm{ft}$ with a micritic internal texture

Sand, fine to medium grading downward to medium to coarse, medium-bluish-gray $(5 B 5 / 1)$; shell fragments abundant; calcitecemented lumps of lithology below in basal $1 \mathrm{ft}$ of interval...

\section{Goose Creek Limestone (?)}

Calcarenite, medium to coarse, light-bluish-gray ( $5 B$ 7/1), partially recrystallized in upper $1 \mathrm{ft}$; no recovery below that until basal $1 \mathrm{ft}$ which has abundant phosphate pebbles, greenish-black $(5 G 2 / 1)$

\section{UNCONFORMITY}

\section{Harleyville Formation, Osborn Member}

Calcarenite, fine, clayey matrix; mostly composed of foraminifera tests; phosphate sand abundant except for 60-65 ft interval; sparse glauconite grains present; some calcite-cemented lumps; grayish yellowish green $(5 G Y 6 / 2)$ grading downward by base to grayish yellowish green $(5 G Y 7 / 2)$ 


\section{Parkers Ferry Formation}

Calcilutite, silty, dense, finely micaceous, dusky-yellowish-green

( $5 G Y 6 / 2$ ); foraminifera tests visible; top interval burrowed and

burrows filled with matrix from unit above.

Base of Wando Formation, upper member:

Base of Wando Formation, middle member:

Base of Wando Formation, lower member:

Base of Goose Creek Limestone:

Base of Harleyville Formation, Osborn Member:

$-12 \mathrm{ft}$ below sea level $-20 \mathrm{ft}$ below sea level $-32 \mathrm{ft}$ below sea level $-\mathbf{4 0} \mathrm{ft}$ below sea level $-49 \mathrm{ft}$ below sea level

\section{Bottomed in Parkers Ferry Formation}


EI-6: $0.5 \mathrm{mi}$ west of eastern quadrangle border, $2.0 \mathrm{mi}$ south of northern quadrangle border, in northeast 1/9th of the quadrangle (latitude $32.5962^{\circ} \mathrm{N}$., longitude $80.2582^{\circ} \mathrm{W}$.). Surface elevation $14 \mathrm{ft}$.

\section{LITHOLOGY}

DEPTH, IN FEET

\section{Wando Formation, upper member}

Sand, fine, well-sorted, slightly silty; mottled brownish black $(5 Y R 2 / 1)$, grayish black $(N 2)$, and yellowish gray $(5 Y 8 / 1)$ grading downward at $2 \mathrm{ft}$ to yellowish gray $(5 Y 7 / 2)$.

Sand, fine, well-sorted, slightly silty, micaceous; contains very fine, dark heavy-mineral grains; yellowish gray $(5 Y 7 / 2)$ grading downward through light olive gray $(5 Y 5 / 2)(10-11 \mathrm{ft})$, yellowish gray $(5 Y 8 / 2)$ $(11-13 \mathrm{ft})$, dark yellowish orange (10YR 6/6) $(13-15 \mathrm{ft})$, pale yellowish orange $(10 Y R$ 8/4) $(15-15.5 \mathrm{ft})$, and then back to dark yellowish orange (10YR 6/6).

Sand, fine to coarse, light-olive-gray (5Y 6/1); phosphate sand abundant; shelly, including Mulinia, Polinices, and others

\section{UNCONFORMITY}

\section{Wando Formation, middle member}

Clay, silty, sticky, light-olive-gray (5Y 7/1)

Sand, fine to medium, light-olive-gray (5Y 6/1); phosphate sand abundant; very shelly with a diverse molluscan fauna

Sand, fine to medium, dark-yellowish-orange (10YR 6/6), sitting on 3 -in.-thick layer of clay, micaceous, medium-light-gray ( $5 B$ 6/1).

Sand, fine to medium grading downward in basal $2 \mathrm{ft}$ of interval to fine to coarse, finely micaceous, shelly including well preserved Oliva, medium-bluish-gray ( $5 B 5 / 1)$; phosphate sand abundant

\section{Marks Head Formation}

Sand, fine, very phosphatic, increasingly clayey downward, stiff, sticky; rounded phosphate pebbles up to $0.5 \mathrm{~cm}$ in diameter scattered throughout; phosphate pebbles more concentrated near base and up to $1.5 \mathrm{~cm}$ in diameter; light olive gray $(5 Y 5 / 2)$ and mottled moderate olive brown $(5 Y 4 / 4)$

\section{UNCONFORMITY}

\section{Parkers Ferry Formation}

Calcilutite, slightly silty, dense, sticky, finely micaceous, dusky-

Base of: Wando Formation, upper member:

Base of Wando Formation, middle member:

Base of Marks Head Formation:

\section{Bottomed in Parkers Ferry Formation}

$-15 \mathrm{ft}$ below sea level $-38 \mathrm{ft}$ below sea level $-46 \mathrm{ft}$ below sea level 
EI-7: $1.15 \mathrm{mi}$ west of eastern quadrangle border, $4.2 \mathrm{mi}$ south of northern quadrangle border, in east-central 1/9th of the quadrangle (latitude $32.5634^{\circ} \mathrm{N}$., longitude $80.2703^{\circ} \mathrm{W}$.). Surface elevation $10 \mathrm{ft}$.

\section{LITHOLOGY}

DEPTH, IN FEET

Road fill, disturbed sand.

$0-1$

Wando Formation, upper member

Sand, fine, humic; very dark yellowish brown (10YR 3/4) grading

downward to very pale orange (10YR $8 / 2)$ and mottled pale yellowish

brown $(10 Y R 6 / 2)$.

Sand, fine, well-sorted, thixotropic; very fine, dark heavy-mineral grains increasingly abundant downward; dark yellowish orange $(10 Y R 6 / 6)$ grading downward through yellowish gray $(5 Y 7 / 2)$ to dusky yellow (5Y 6/4).....

Sand, fine, very fine, thixotropic, very-pale-orange (10YR 8/2); dark

heavy-mineral grains abundant; shelly, including oyster, Noetia,

Mulinia, and others; scattered calcite-cemented nodules present.....

Sand, fine to medium, medium-bluish-gray ( $5 B 5 / 1)$; very shelly at top

and less shelly downward; 4 -in.-thick clay bed at $34 \mathrm{ft}$.

Clay, silty, micaceous, medium-bluish-gray ( $5 B 5 / 1)$; contains frequent

laminae of very fine silty sand.

Sand, fine to medium, very phosphatic, medium-bluish-gray ( $5 B 5 / 1)$;

contains lenses of shell hash

Sand, medium to coarse, shelly, medium-bluish-gray ( $5 B 5 / 1)$; contains

rounded phosphate granules

-UNCONFORMITY

\section{Wando Formation, middle member}

Sand, fine, well-sorted, silty, no shells, thixotropic, medium-bluishgray $(5 B 5 / 1)$; very fine, dark heavy-mineral grains abundant; subrounded phosphate pebbles up to $1 \mathrm{~cm}$ common at base.

UNCONFORMITY

\section{Harleyville Formation, Osborn Member}

Calcarenite, fine, grainy, pale-olive (10Y 6/2); contains mollusk shell

fragments; contains NP 21 nannofossil assemblage $66-75$

Base of: Wando Formation, upper member:

Base of Wando Formation, middle member:

\section{Bottomed in Harleyville Formation, Osborn Member}


EI-8: $\quad 3.3 \mathrm{mi}$ west of eastern quadrangle border, $1.75 \mathrm{mi}$ south of northern quadrangle border, in north-central $1 / 9$ th of the quadrangle (latitude $32.5998^{\circ} \mathrm{N}$., longitude $80.3058^{\circ} \mathrm{W}$.). Surface elevation $7 \mathrm{ft}$.

\section{LITHOLOGY}

DEPTH, IN FEET

\section{Silver Bluff beds}

Sand, fine, well-sorted, thixotropic; dark yellowish orange (10YR 6/6)

grading downward through pale yellowish orange $(10 Y R$ 8/6) and

mottled yellowish gray $(5 Y 8 / 1)(2-8 \mathrm{ft})$ back to dark yellowish orange

(10YR 6/6)

Clay, silty, sticky, finely micaceous, medium-bluish-gray $(5 B 5 / 1)$;

sharp basal contact.

\section{-UNCONFORMITY}

\section{Wando Formation, upper member}

Sand, medium to coarse, subrounded to rounded, light-olive-gray

(5Y 6/1); shell fragments increasingly abundant downward; basal $1 \mathrm{ft}$

has coarse to very coarse rounded quartz grains and very coarse to

granule-size rounded grains of phosphate

\section{UNCONFORMITY}

\section{Wando Formation, middle member}

Clay, silty, sandy, medium-bluish-gray (5B 5/1)

Sand, medium to coarse, medium-light-gray ( $N$ 6); sparsely shelly, mostly oysters

-UNCONFORMITY

\section{Marks Head Formation}

Sand, clayey, silty; rounded phosphate pebbles up to $1 \mathrm{~cm}$ in diameter in basal $1 \mathrm{ft}$; moderate olive brown $(5 Y 4 / 4)$ grading downward to dark olive brown $(5 Y 4 / 2)$

\section{UNCONFORMITY}

\section{Harleyville Formation, Osborn Member}

Calcarenite, silty, soft, pale-olive (10Y 6/2); foraminifera tests abundant; scattered calcite-cemented lumps present

Base of Silver Bluff beds:

Base of Wando Formation, upper member:

Base of Wando Formation, middle member:

Base of Marks Head Formation:

$-20 \mathrm{ft}$ below sea level

$-31 \mathrm{ft}$ below sea level

-36 ft below sea level

$-44 \mathrm{ft}$ below sea level

\section{Bottomed in Harleyville Formation, Osborn Member}


EI-9: $0.65 \mathrm{mi}$ east of western quadrangle border, $2.4 \mathrm{mi}$ north of southern quadrangle border, in southwest 1/9th of the quadrangle (latitude $32.5357^{\circ}$ N., longitude $80.3643^{\circ} \mathrm{W}$.). Surface elevation $17 \mathrm{ft}$.

\section{LITHOLOGY}

DEPTH, IN FEET

\section{Wando Formation, upper member}

Sand, fine, well-sorted, loose; very fine, dark heavy-mineral grains increasingly abundant downward; grayish orange (10YR 7/4) grading downward through grayish yellow $(5 Y 8 / 4)(3-10 \mathrm{ft})$ to yellowish gray $(5 Y 8 / 1)$

Sand, fine, well-sorted, micaceous; very fine, dark heavy-mineral grains abundant; yellowish gray $(5 Y 8 / 1)$ grading downward through moderate greenish yellow $(10 Y 7 / 4)(19-24 \mathrm{ft})$ to moderate brown (5YR 5/5) interlayered with moderate greenish yellow (10Y7/4) $(24-27 \mathrm{ft})$

Sand, fine, well-sorted, micaceous, shelly; very fine, dark heavymineral grains abundant; yellowish gray $(5 Y 7 / 2)$ grading downward at $31 \mathrm{ft}$ to medium light gray ( $N 5$ to $N 6$ )

Peat, dusky-brown $(5 Y 2 / 2)$

Clay, silty, stiff, grading downward to sand, very fine to fine, micaceous; grayish brown $(5 Y R 3 / 2)$ grading downward to interbedded grayish olive (10Y 4/2) and dark greenish gray (5GY 4/1)

Sand, fine, silty and clayey, moderately shelly, medium-dark-gray $(N 4)$; phosphate pebbles and quartz pebbles up to $0.5 \mathrm{~cm}$ in diameter abundant in basal 4 in.; sharp basal contact

\section{UNCONFORMITY}

\section{Wando Formation, middle member}

Sand, medium to coarse, subrounded to rounded; shell fragments abundant including fragments of Mercenaria; medium dark gray $(N 4)$ grading downward at $50 \mathrm{ft}$ to medium bluish gray $(5 B 6 / 1)$

Clay, sandy (very fine), medium-bluish-gray ( $5 B 6 / 1)$; sharp basal contact

\section{UNCONFORMITY}

\section{Daniel Island beds}

Sand, fine, well-sorted, light-gray $(N 7)$; very fine to fine, dark heavymineral grains abundant; clay stringers, medium-gray $(N 5)$, present in basal $1 \mathrm{ft}$; basal 2 in. contains coarse to very coarse rounded quartz sand and medium to coarse rounded phosphate sand

\section{UNCONFORMITY}

\section{Goose Creek Limestone}

Calcarenite, medium to coarse; phosphate sand abundant; calcitecemented lumps present; light gray $(N 7)$ to very light gray $(N 8)$ grading downward $60 \mathrm{ft}$ to medium light gray $(N 6)$; sharp basal contact 


\section{Marks Head Formation}

Clay, silty, finely micaceous, moderate-olive-brown (5Y 4/4) to olivegray $(5 Y 3 / 2)$; grades downward to

Sand, mostly fine, silty, clayey, micaceous, moderate-olive-brown

(5Y 4/4) to olive-gray (5Y3/2); basal $5 \mathrm{ft}$ contains scattered medium to

coarse grains; dense phosphate bed at base.

UNCONFORMITY

Harleyville Formation, Osborn Member

Calcarenite, soft, grainy, silty, finely micaceous, moderate-olive-brown

(5Y 4/4) to olive-gray (5Y3/2); thin mollusk shell fragments at base

UNCONFORMITY

\section{Parkers Ferry Formation}

Calcilutite, dense, stiff, pale-grayish-olive (10Y 5/2); sparse scattered

foraminifera tests present; cut surfaces have a sheen; burrows in upper

$1 \mathrm{ft}$ filled with overlying lithology.

Base of: Wando Formation, upper member:

Base of Wando Formation, middle member:

Base of Daniel Island beds:

Base of Goose Creek Limestone:

Base of Marks Head Formation:

Base of Harleyville Formation, Osborn Member:

Bottomed in Parkers Ferry Formation
$-28 \mathrm{ft}$ below sea level

$-\mathbf{4 0} \mathrm{ft}$ below sea level

$-42 \mathrm{ft}$ below sea level

$-53 \mathrm{ft}$ below sea level

$-68 \mathrm{ft}$ below sea level

$-74 \mathrm{ft}$ below sea level 
EI-10: $2.75 \mathrm{mi}$ east of western quadrangle border, $3.1 \mathrm{mi}$ north of southern quadrangle border, in central 1/9th of the quadrangle (latitude $32.5452^{\circ}$ N., longitude $80.3286^{\circ} \mathrm{W}$.). Surface elevation $10 \mathrm{ft}$.

\section{LITHOLOGY}

DEPTH, IN FEET

Road fill, disturbed clay.

$0-1$

Wando Formation, upper member

Sand, fine, well-sorted; very fine, dark heavy-mineral grains increasingly abundant downward; medium yellowish brown (10YR 4/4)

grading downward through grayish orange (10YR 7/4) streaked light

olive gray $(5 Y 5 / 2)(2-9 \mathrm{ft})$ and through greenish gray $(5 G 6 / 1)$

$(9-10 \mathrm{ft})$ to grayish green $(10 G 4 / 2)$

Sand, fine, well-sorted, medium-bluish-gray ( $5 B 5 / 1)$; very fine, dark

heavy-mineral grains abundant; shelly, including Mulinia, Oliva,

Anadara brasiliana, and many others.

Clay, silty, greasy, sparsely micaceous, medium-bluish-gray (5B 4/1)

Sand, silty, clayey, medium-bluish-gray ( $5 B 4 / 1)$; sparsely shelly, mostly oyster and Mulinia .....

Sand, fine grading downward to medium and coarse, light-gray $(N 7)$;

fine to medium phosphate sand abundant; increasingly shelly

downward and fauna more diverse downward

UNCONFORMITY

\section{Wando Formation, middle member}

Clay, silty and sandy, medium-dark-gray $(N 4)$; grades downward to

Sand, fine, well-sorted, sparsely shelly; very fine, dark heavy-mineral grains abundant; scattered quartz and phosphate granules present; medium dark gray $(N 4)$ grading downward to medium gray $(N 5)$; grades rapidly downward to.

Sand, medium to coarse, medium-gray ( $N 5)$; granules of quartz and phosphate abundant; rounded shell fragments abundant

\section{UNCONFORMITY}

\section{Daniel Island beds}

Clay, stiff, sticky, finely micaceous; dark greenish gray (5GY 4/1) grading downward to dark greenish gray $(5 G 4 / 1)$....

Sand, very fine to fine, clayey, silty, medium-bluish-gray ( $5 B 5 / 1)$;

coarse to very coarse grains scattered within; abundant oyster

fragments and rounded to subrounded phosphate pebbles up to $1 \mathrm{~cm}$ in

diameter 


\section{Marks Head Formation}

Sand, fine, clayey, silty; upper $1 \mathrm{ft}$ brownish olive gray (5Y 3/4)

grading downward to moderate olive brown $(5 Y 4 / 4)$.....

$62-65$

Base of Wando Formation, upper member:

$-25 \mathrm{ft}$ below sea level

Base of Wando Formation, middle member:

$-41 \mathrm{ft}$ below sea level

Base of Daniel Island beds:

$-52 \mathrm{ft}$ below sea level

Bottomed in Marks Head Formation 


\section{Fenwick Quadrangle}

FE-1: $1.4 \mathrm{mi}$ west of eastern quadrangle border, $4.15 \mathrm{mi}$ south of northern quadrangle border, in east-central 1/9th of the quadrangle (latitude $32.6895^{\circ} \mathrm{N}$., longitude $80.3995^{\circ} \mathrm{W}$.). Surface elevation $44 \mathrm{ft}$.

\section{LITHOLOGY}

DEPTH, IN FEET

\section{Ten Mile Hill Formation}

Sand, upper fine to lower medium, well-sorted, clean; dusky brown

(5YR 2/2) and mottled moderate yellowish brown (10YR 5/4)

Sand, upper fine to lower medium, well-sorted, clean; very fine, dark

heavy-mineral grains abundant; dark yellowish orange (10YR 6/6)

grading downward at $2 \mathrm{ft}$ to very pale orange (10YR 7/2)....

Sand, fine, silty, grayish-yellow (5Y 7/4); very fine, dark heavy-mineral

grains present; 3 -in.-thick lens of sandy, yellowish-gray (5Y 8/1) clay at

$8 \mathrm{ft}$

Sand, upper fine to lower medium, well-sorted, silty, yellowish-gray

(5Y 6/2); very fine, dark heavy-mineral grains abundant

Sand, dominantly fine but with a minor rounded medium fraction; fine, dark heavy-mineral grains abundant; grayish yellow (5Y7/4) grading downward in basal $1 \mathrm{ft}$ to pale yellowish gray $(5 Y 8 / 2)$.

Sand, dominantly fine but with a minor rounded medium fraction, clayey, silty; fine, dark heavy-mineral grains abundant; pale yellowish gray $(5 Y 8 / 2)$ grading downward by $25 \mathrm{ft}$ to dark yellowish orange (10YR 6/6).

Silt, clayey, sandy (very fine), greasy, yellowish-gray (5Y 7/2)

Sand, fine, well-sorted, thixotropic; very fine, dark heavy-mineral grains abundant; dark yellowish brown $(10 Y R$ 4/6) grading downward through yellowish orange $(10 Y R 7 / 6)(33-40 \mathrm{ft})$ to olive gray $(5 Y 5 / 1)$

Sand, fine, slightly silty, medium-bluish-gray ( $5 B 5 / 1)$; contains sparse very fine, dark heavy-mineral grains

Sand, fine, silty, medium-bluish-gray ( $5 B 5 / 1)$; contains sparse lustrous shells; abundant rounded phosphate lumps up to $4 \mathrm{~cm}$ in diameter in basal $1 \mathrm{ft}$

\section{UNCONFORMITY}

\section{Ashley Formation, Runnymede Marl Member}

Calcarenite, fine, phosphatic, moderate-olive-brown (5Y 4/4); contains

\section{Bottomed in Ashley Formation, Runnymede Marl Member}


FE-2: $2.05 \mathrm{mi}$ west of eastern quadrangle border, $1.05 \mathrm{mi}$ south of northern quadrangle border, in northeast 1/9th of the quadrangle (latitude $32.7348^{\circ}$ N., longitude $80.4102^{\circ}$ W.). Surface elevation $8 \mathrm{ft}$.

\section{LITHOLOGY}

DEPTH, IN FEET

Fill, swirled and mottled sand.

$0-1$

\section{Holocene floodplain sediments}

Sand, increasingly silty downward; very fine to fine, dark heavy-

mineral grains abundant; yellowish gray $(5 Y 7 / 2)$ and mottled orange

$(10 Y R 5 / 6)$ below $3 \mathrm{ft}$.

Sand, silty, clayey, pale-olive-gray ( $5 Y 6 / 2)$; very fine to fine, dark heavy-mineral grains abundant.

Sand, medium to very coarse, subrounded, silty, soft; dark grayish orange (10YR 6/4) grading downward at about $14 \mathrm{ft}$ to olive brown $(5 Y 3 / 4)$

\section{UNCONFORMITY}

\section{Edisto Formation}

Sand, silty, slightly clayey, calcareous, phosphatic, very finely micaceous; moderate olive gray $(5 Y 4 / 2)$ grading downward through olive brown (5Y3/4) to light olive brown (5Y 5/4); NP 24/25

nannofossil assemblage recovered at $28 \mathrm{ft}$; hard bed at base.

Sand, fine to coarse, poorly sorted, coarse fraction well rounded and polished, calcareous, clayey, stiff, light-olive-brown ( $5 Y 5 / 4)$; contains scattered calcite-cemented lumps

Sand, medium to coarse, clayey, light-olive-brown (5Y 5/4); phosphate and glauconite sand abundant; hard bed at base

\section{UNCONFORMITY}

\section{Harleyville Formation, Osborn Member}

Calcarenite, fine; composed mostly of foraminifera tests; basal $3 \mathrm{ft}$ has abundant quartz and phosphate sand; light olive brown (5Y 5/4) grading downward at base to dark grayish yellow $(5 Y 7 / 4)$.....

\section{Parkers Ferry Formation}

Calcilutite, silty, sticky, light-grayish-olive (10Y 5/2); very hard to cut off stems

Base of Holocene floodplain sediments:

Base of Edisto Formation:

Base of Harleyville Formation, Osborn Member

\section{Bottomed in Parkers Ferry Formation}

$-12 \mathrm{ft}$ below sea level

$-40 \mathrm{ft}$ below sea level

$-74 \mathrm{ft}$ below sea level 
FE-3: 0.9 mi west of eastern quadrangle border, $2.8 \mathrm{mi}$ north of southern quadrangle border, in southeast 1/9th of the quadrangle (latitude $32.6655^{\circ}$ N., longitude $80.3902^{\circ}$ W.). Surface elevation $7 \mathrm{ft}$.

\section{LITHOLOGY}

DEPTH, IN FEET

\section{Wando Formation, upper member}

Sand, very fine to fine, silty, stiff; yellowish gray (5Y7/2) and mottled yellowish orange $(10 Y R 7 / 6)$

Silt, clayey, sandy (very fine), stiff; contains lenses of very fine to fine sand in basal $2 \mathrm{ft}$; pale olive gray $(5 Y 6 / 2)$ and mottled dark yellowish orange (10YR 6/6) grading downward to dark yellowish orange $(10 Y R 6 / 6)$ and mottled pale olive gray $(5 Y 6 / 2)$; grades rapidly downward to

Silt, slightly clayey, sandy (very fine), greasy, finely micaceous, medium-greenish-gray $(5 G Y 5 / 1)$; contains scattered lenses of very fine sand.

Sand, fine, slightly silty, micaceous, medium-greenish-gray (5GY 5/1); contains sparse very fine to fine, dark heavy-mineral grains.

Sand, fine to medium, medium-greenish-gray ( $5 G Y 5 / 1)$; sparsely

shelly, mostly Mulinia

Silt, medium-greenish-gray $(5 G Y 5 / 1)$

Sand, fine to medium, medium-greenish-gray ( $5 G Y 5 / 1)$; basal $1 \mathrm{ft}$ contains black $(N 1)$ rounded phosphate pebbles up to $5 \mathrm{~cm}$ in diameter

UNCONFORMITY

\section{Harleyville Formation, Osborn Member}

Calcarenite, fine, light-olive-brown ( $5 Y$ 5/4); occasional phosphate and calcite-cemented lumps present

Calcarenite, lithified, phosphatic; no reliable color; very hard drilling

\section{-UNCONFORMITY}

\section{Parkers Ferry Formation}

Calcisiltite interbedded with calcilutite, silty, clayey, sticky; light grayish olive $(10 Y 5 / 2)$; hard to cut off auger flights $36-56$

Base of Wando Formation, upper member: Base of Harleyville Formation, Osborn Member

\section{Bottomed in Parkers Ferry Formation}


FE-4: $1.5 \mathrm{mi}$ west of eastern quadrangle border, $3.25 \mathrm{mi}$ south of northern quadrangle border, in east-central 1/9th of the quadrangle (latitude $32.7031^{\circ}$ N., longitude $80.4001^{\circ}$ W.). Surface elevation $18 \mathrm{ft}$.

\section{LITHOLOGY}

DEPTH, IN FEET

\section{Ten Mile Hill Formation}

Sand, fine, well-sorted; no color recorded. $0-1$

Sand, fine, silty, clayey, stiff; no color recorded . $1-6$

Sand, upper fine to lower medium, well-sorted, silty; contains sparse dark heavy-mineral grains; no color recorded .

Silt, clayey, sandy (very fine), micaceous; no color recorded

Sand, fine, well-sorted, increasingly silty downward, micaceous, thixotropic; no color recorded; grades rapidly downward to....

Sand, medium to very coarse, poorly sorted; contains subangular to subrounded quartz pebbles up to $2 \mathrm{~cm}$ in diameter; phosphate granules and pebbles present in basal $3 \mathrm{ft}$; no color recorded.

\section{UNCONFORMITY}

\section{Daniel Island beds}

Clay, silty, sandy (very fine), dense, sticky, micaceous; interbedded with thin lenses of very fine sand and clay; medium dark gray $(N 4)$

Sand, fine to medium, medium-dark-gray $(N 4)$; contains phosphate pebbles and reworked clasts of Marks Head and Harleyville lithology

\section{Harleyville Formation, Osborn Member}

Calcarenite, fine to medium, grainy, slightly silty, yellowish-gray

(5Y 7/2); composed mostly of foraminifera tests; contains sparse shell

fragments; sharp basal contact.

-UNCONFORMITY

\section{Parkers Ferry Formation}

Calcilutite, silty, dense, sticky, massive, pale-olive (10Y 6/2).

Base of Ten Mile Hill Formation:

Base of Daniel Island beds:

Base of Harleyville Formation, Osborn Member:

\section{Bottomed in Parkers Ferry Formation}


FE-5: $2.75 \mathrm{mi}$ east of western quadrangle border, $0.95 \mathrm{mi}$ south of northern quadrangle border, in north-central $1 / 9$ th of the quadrangle (latitude $32.7366^{\circ} \mathrm{N}$., longitude $80.4524^{\circ}$ W.). Surface elevation $10 \mathrm{ft}$.

LITHOLOGY

DEPTH, IN FEET

\section{Wando Formation, upper member}

Sand, fine, well-sorted, silty, dusky-yellow (5Y 6/4); very fine, dark

heavy-mineral grains abundant; grades downward to...

Silt, clayey, sandy (very fine), stiff, slightly sticky, sparsely micaceous; very fine sand lenses scattered throughout; yellowish orange (10YR 7/6)

and light olive gray $(5 Y 5 / 2)$ and mottled grading downward to pale

olive gray $(5 Y 4 / 2)$ and mottled dark grayish green $(5 G 4 / 2)$......

Sand, fine, silty, slightly clayey, moderate-olive-gray ( $5 Y 4 / 2)$; contains

sparse rounded phosphate granules; dark heavy-mineral grains

abundant

$11-24$

UNCONFORMITY-

\section{Marks Head Formation}

Silt, sandy (very fine), clayey, grading downward to fine, silty sand; phosphate sand grains scattered throughout; olive brown (5Y3/4);

grades downward to.

Gravel, composed of phosphate lumps and fragments of Edisto

Formation lithology both phosphate and calcite cemented; matrix

consists of sand, fine to medium; olive brown (5Y3/4).

\section{UNCONFORMITY}

\section{Edisto Formation}

Sand, fine, calcitic-silty, very calcareous, sparsely shelly, light-olivegray $(5 Y 6 / 1)$; indurated zone at base.. $30-33$

\section{Ashley Formation, Givhans Ferry Member}

Sand, fine; olive gray (5Y3/2) grading downward to dark olive gray

$(5 Y 2 / 2)$

Sand, fine, calcareous, light-olive-brown ( $5 Y 5 / 4)$; tough drilling

Sand, fine to medium, calcite-indurated, light-olive-brown (5Y 5/4);

phosphate pebbles and shell fragments abundant

\section{UNCONFORMITY}

\section{Ashley Formation, Runnymede Marl Member}

Calcarenite, fine, light-olive-brown (5Y 5/4); foraminifera tests

abundant $37-46$

Calcarenite, lithified, pale-olive-gray ( $5 Y$ 6/2); tough drilling $46-47$ 
Calcarenite, fine, clayey, dense, light-olive-brown ( $5 Y$ 5/4); composed

mostly of foraminifera tests; contains occasional granules of phosphate

and giant foraminifera; tough to get off stems

Base of Wando Formation, upper member:

$-14 \mathrm{ft}$ below sea level

Base of Marks Head Formation:

Base of Edisto Formation:

Base of Ashley Formation, Givhans Ferry Member:

$-20 \mathrm{ft}$ below sea level

$-23 \mathrm{ft}$ below sea level

$-27 \mathrm{ft}$ below sea level

Bottomed in Ashley Formation, Runnymede Marl Member 
FE-6: $2.4 \mathrm{mi}$ west of eastern quadrangle border, $3.65 \mathrm{mi}$ north of southern quadrangle border, in east-central 1/9th of the quadrangle (latitude $32.6786^{\circ}$ N., longitude $80.4160^{\circ}$ W.). Surface elevation $5 \mathrm{ft}$.

LITHOLOGY

DEPTH, IN FEET

Fill, sand and garbage, brick fragments at base .

$0-7$

\section{Silver Bluff beds}

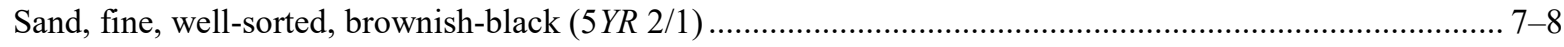

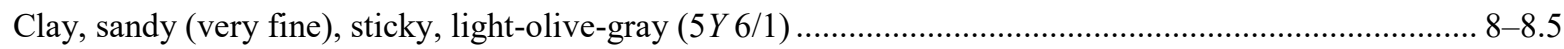

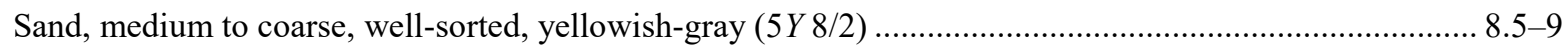

UNCONFORMITY

\section{Ten Mile Hill Formation}

Sand, fine, well-sorted, micaceous; dark yellowish orange (10YR 6/6) and mottled white $(N 9)$ grading downward to entirely dark yellowish orange $(10 Y R 6 / 6)$.

Sand, fine, micaceous, dark-yellowish-orange (10YR 6/6); interbedded with clay, silty, brownish-orange $(7.5 Y R$ 6/6) and mottled very-paleorange $(10 Y R 8 / 2)$.

Clay, micaceous, medium-light-gray (N 6); interbedded with sand, very

fine, clayey, medium-gray ( $N 5)$.

Sand, fine, well-sorted, medium-gray ( $N 5)$; contains sparse very fine, dark heavy-mineral grains; a few 1- to 3-in.-thick clay stringers scattered throughout interval

Sand, fine to medium, medium-gray ( $N 5)$; contains abundant subangular to subrounded phosphate nodules up to $4 \mathrm{~cm}$ in diameter.

-UNCONFORMITY-

\section{Marks Head Formation}

Sand, fine, clayey, silty, dense, finely micaceous; at base contains rounded phosphate nodules up to $4 \mathrm{~cm}$ in diameter; medium olive brown (5Y 4.5/4) with rare mottles of dusky yellow $(5 Y 6 / 4)$ and moderate olive brown $(5 Y 4 / 4)$.

\section{UNCONFORMITY}

\section{Harleyville Formation, Osborn Member}

Calcarenite, fine, calcitic-silty, calcitic-clayey, dense; contains common calcite-cemented lumps; interbedded layers colored olive black (5Y2/2) and pale olive $(10 Y 6 / 2)$

Calcarenite, fine, grainy, soft, pale-olive (10Y 6/2); contains sparse

phosphate and glauconite sand in basal $1 \mathrm{ft}$; sharp basal contact 


\section{Parkers Ferry Formation}

Calcilutite, slightly silty, dense, stiff, dusky-yellowish-green (5GY 5/2);

fine mica flakes abundant $50-59$

Base of Silver Bluff beds:

Base of Ten Mile Hill Formation:

Base of Marks Head Formation:

Base of Harleyville Formation, Osborn Member:

$-4 \mathrm{ft}$ below sea level

$-\mathbf{2 8} \mathrm{ft}$ below sea level

$-36 \mathrm{ft}$ below sea level

Bottomed in Parkers Ferry Formation

$-45 \mathrm{ft}$ below sea level 
FE-7: $1.45 \mathrm{mi}$ east of western quadrangle border, $0.65 \mathrm{mi}$ north of southern quadrangle border, in southwest $1 / 9$ th of the quadrangle (latitude $32.6345^{\circ} \mathrm{N}$., longitude $80.4753^{\circ}$ W.). Surface elevation $13 \mathrm{ft}$.

\section{LITHOLOGY}

DEPTH, IN FEET

\section{Wando Formation, upper member}

Sand, fine, well-sorted; dark yellowish brown (10YR 3/2) grading downward through dark yellowish orange $(10 Y R$ 6/6) to very pale orange (10YR 8/2).

Sand, fine, yellowish-gray ( $5 Y 7 / 2)$; minor medium to coarse fraction present; very fine, dark heavy-mineral grains present....

Clay, greasy, medium-bluish-gray $(5 B 5 / 1)$

Sand, fine, medium-bluish-gray ( $5 B 5 / 1)$; shelly, including Oliva among others

Clay, greasy, medium-bluish-gray $(5 B 5 / 1)$

Sand, very fine to fine, silty, grading downward to fine to coarse, poorly sorted, rounded, sparsely shelly; medium bluish gray $(5 B 5 / 1)$.

Sand, fine, well-sorted, medium-bluish-gray ( $5 B 5 / 1)$; black ( $N 1)$ rounded phosphate pebbles up to $4 \mathrm{~cm}$ in diameter at base

\section{UNCONFORMITY}

\section{Marks Head Formation}

Sand, very fine to fine, silty, clayey, finely micaceous, olive-brown

(5Y 3/4); grades downward to.

Sand, very fine to fine, slightly silty, slightly clayey, olive-brown

(5Y3/4)

Gravel, consists of lumps of rounded black $(N 1)$ phosphate and one lump of pale-olive-gray ( $5 Y 7 / 1)$ Edisto Formation lithology

\section{Ashley Formation, Runnymede Marl Member}

Calcarenite, fine, quartzose and phosphatic, light-olive-brown (5Y 5/4);

large foraminifera tests abundant.

Base of Wando Formation, upper member:

Base of Marks Head Formation:

\section{Bottomed in Ashley Formation, Runnymede Marl Member}


FE-8: $\quad 3.6 \mathrm{mi}$ west of eastern quadrangle border, $1.0 \mathrm{mi}$ north of southern quadrangle border, in south-central $1 / 9$ th of the quadrangle (latitude $32.6396^{\circ}$ N., longitude $80.4369^{\circ}$ W.). Surface elevation $7 \mathrm{ft}$.

\section{LITHOLOGY}

DEPTH, IN FEET

\section{Wando Formation, upper member}

Sand, fine, well-sorted, clean; dark yellowish brown (10YR 3/2)

grading rapidly downward to dark yellowish orange $(10 Y R 6 / 6)$

Sand, fine, well-sorted, clean, micaceous; very fine, dark heavy-mineral grains present; pale yellowish brown (10YR 6/2) and mottled orange

(10YR 5/6); grades downward to

Sand, fine, silty, clayey; pale olive (10Y7/2) grading downward through grayish yellow $(5 Y 7 / 4)(6-7 \mathrm{ft})$ and olive brown $(5 Y 5 / 4)$

$(7-7.5 \mathrm{ft})$ to medium greenish gray $(5 G 7 / 1)$

Clay, silty, sandy (very fine), medium-greenish-gray ( $5 G 5 / 1)$; with

lenses of very fine to fine sand

Sand, mostly fine but with a minor rounded medium to coarse fraction,

silty, thixotropic; pale olive $(10 Y 6 / 2)$ grading downward at about $20 \mathrm{ft}$

to medium greenish gray $(5 G 5 / 1)$.

Clay, silty, greasy, medium-greenish-gray ( $5 G 5 / 1)$; contains layers of

sandy silt with poorly preserved shells (Noetia and Anadara, among

others) at 24-25 ft, 26-27 ft, 36-37 ft, and 41-42 ft

Gravel, irregularly shaped lumps of black $(N 1)$ phosphate up to $6 \mathrm{~cm}$

long, clayey and sandy matrix

\section{UNCONFORMITY}

\section{Ashley Formation, Runnymede Marl Member}

Calcarenite, fine, phosphatic, clayey, light-olive-brown (5Y 5/4)

Calcarenite, fine, phosphatic, sparsely quartzose, finely micaceous,

moderate-olive-brown (5Y 4/4); grades rapidly downward to

Sand, medium to coarse, calcareous, phosphatic, glauconitic; lens of grayish yellow $(5 Y 7 / 4)$ at top grading rapidly downward to light olive brown $(5 Y 5 / 4)$

UNCONFORMITY

\section{Harleyville Formation, Osborn Member}

Calcarenite, fine, moderately soft, pale-olive (10Y 6/2)

$63-101$

Base of Wando Formation, upper member:

Base of Ashley Formation, Runnymede Marl Member:

\section{Bottomed in Harleyville Formation, Osborn Member}

$-48 \mathrm{ft}$ below sea level $-56 \mathrm{ft}$ below sea level 
FE-9: $1.0 \mathrm{mi}$ east of western quadrangle border, $4.3 \mathrm{mi}$ south of northern quadrangle border, in west-central $1 / 9$ th of the quadrangle (latitude $32.6873^{\circ}$ N., longitude $80.4823^{\circ}$ W.). Surface elevation $7 \mathrm{ft}$.

\section{LITHOLOGY}

DEPTH, IN FEET

\section{Silver Bluff beds}

Sand, very fine to fine, clayey, stiff, dense; dark yellowish gray (5Y 6/2) and mottled dark yellowish orange (10YR 6/6)

Sand, fine, coarsening downward to medium to very coarse, poorly sorted, subangular to subrounded; dark yellowish gray $(5 Y 6 / 2)$ and mottled dark yellowish orange (10YR 6/6), grading downward in basal $0.5 \mathrm{ft}$ to dusky yellow (5Y 6/4) .

\section{-UNCONFORMITY}

\section{Wando Formation, upper member}

Sand, very fine, silty, clayey; clay lens at $8 \mathrm{ft}$; orange $(10 Y R 5 / 6)$ and mottled dark yellowish orange (10YR 6/6)

Sand, fine, well-sorted, clean, micaceous, greenish-gray (5GY 6/1); very fine, dark heavy-mineral grains present.

Clay, silty, micaceous, medium-greenish-gray ( $5 G 5 / 1)$; contains a thin few layers of very fine to fine silty sand; grades downward to

Sand, fine, silty, clayey, phosphatic, medium-bluish-gray (5B 4/1); contains Mulinia shells

\section{UNCONFORMITY}

\section{Edisto Formation (?)}

Chert, recovered pale olive (10Y 6/2) and greenish black (5G 2/1)

fragments from drill bit; auger would not advance so hole was abandoned.

Base of Silver Bluff beds:

Base of Wando Formation, upper member:

\section{Bottomed on Edisto Formation (?)}




\section{Harleyville Quadrangle}

HV-1: $0.6 \mathrm{mi}$ east of western quadrangle border, $0.55 \mathrm{mi}$ south of northern quadrangle border, in northwest 1/9th of the quadrangle (latitude $33.2426^{\circ}$ N., longitude $80.4894^{\circ} \mathrm{W}$.). Surface elevation $106 \mathrm{ft}$.

\section{LITHOLOGY}

DEPTH, IN FEET

\section{Waccamaw Formation (?)}

Sand, fine to very coarse, very poorly sorted, silty, clayey, sticky; grayish orange $(10 Y R 7 / 4)$ grading downward through dark yellowish orange $(10 Y R 6 / 6)(1-5 \mathrm{ft})$ to reddish orange $(10 R 5 / 6)$ and mottled light yellowish gray $(5 Y 8 / 2)$ $0-8$

Clay, silty, tough, light-yellowish-gray (5Y 8/2)

Sand, fine to very coarse, very poorly sorted, silty, slightly clayey, grading downward near base to dominantly fine with medium to coarse fraction; very pale orange $(10 Y R 8 / 2)$.

\section{UNCONFORMITY}

\section{Ashley Formation, Runnymede Marl Member}

Calcarenite, fine, phosphatic but not quartzose; light grayish orange

(10YR 8/4) grading downward by $33 \mathrm{ft}$ to greenish yellow $(10 Y 7 / 2)$ $31-35$

Very hard indurated bed, hard to penetrate at 35

Calcarenite, fine, phosphatic but not quartzose, greenish-yellow (10Y7/2); composed of foraminifera tests; basal 2-ft interval contains abundant phosphate and glauconite sand; alternating normal and very hard drilling, stopped at or very near base of unit $35-51$

Base of Waccamaw Formation (?):

Base of Ashley Formation, Runnymede Marl Member:

$+75 \mathrm{ft}$ above sea level $+55 \mathrm{ft}$ above sea level

\section{Bottomed on or just above Tupelo Bay Formation, Pregnall Member (?)}


HV-2: $1.45 \mathrm{mi}$ east of western quadrangle border, $4.3 \mathrm{mi}$ south of northern quadrangle border, in west-central $1 / 9$ th of the quadrangle (latitude $33.1874^{\circ} \mathrm{N}$., longitude $80.4767^{\circ}$ W.). Surface elevation $82 \mathrm{ft}$.

\section{LITHOLOGY}

DEPTH, IN FEET

\section{Wicomico formation}

Sand, mostly fine to medium but with a minor coarse to very coarse fraction, subrounded to rounded, clayey; dark yellowish brown $(10 Y R 4 / 2)$ grading downward at $1 \mathrm{ft}$ to dark yellowish orange $(10 Y R$ 6/6) and mottled reddish orange (10R 5/6) and light reddish gray (5R 6/1); grades downward to. $0-9$

Sand, fine to coarse, poorly sorted, clean, thixotropic, pinkish-gray (5YR 8/1).......

Sand, fine to medium, better sorted than above, silty, slightly thixotropic, pale-grayish-orange $(10 Y R 8 / 4)$; contains very fine to fine, dark heavy-mineral grains ..... $11-16$

Sand, coarse to very coarse, subrounded to rounded, pale-grayishorange $(10 Y R 8 / 4)$.

UNCONFORMITY

\section{Raysor Formation}

Sand, fine, well-sorted, clayey, silty, dark-yellowish-brown (10YR 3/2)

\section{Ashley Formation, Runnymede Marl Member}

Calcarenite, fine, increasingly phosphatic downward; shell fragments present; light olive brown (5Y 5/4) grading downward by $18 \mathrm{ft}$ to light grayish olive (10Y 5/2); NP 24 nannofossil assemblage at $28 \mathrm{ft}$.

Calcarenite, fine, light-grayish-olive (10Y 5/2); very abundant phosphate sand and granules; a few rounded coarse to very coarse quartz grains; stopped at or very near base of unit .....

Base of Wicomico formation:

Base of Raysor Formation:

Base of Ashley Formation, Runnymede Marl Member:
$+65 \mathrm{ft}$ above sea level $+64.5 \mathrm{ft}$ above sea level $+36 \mathrm{ft}$ above sea level

Bottomed on or just above Tupelo Bay Formation, Pregnall Member (?) 
HV-3: $2.05 \mathrm{mi}$ west of eastern quadrangle border, $3.95 \mathrm{mi}$ south of northern quadrangle border, in east-central $1 / 9$ th of the quadrangle (latitude $33.1934^{\circ}$ N., longitude $80.4096^{\circ}$ W.). Surface elevation $77 \mathrm{ft}$.

\section{LITHOLOGY}

DEPTH, IN FEET

Sand, fine to very coarse, very poorly sorted, berm fill; mixed

yellowish brown (10YR 5/2) and very dark yellowish brown (10YR 3/2)

-UNCONFORMITY

\section{Wicomico formation}

Sand, mostly fine to medium but with minor coarse to very coarse fraction, silty and slightly clayey in top $4 \mathrm{ft}$ but cleaner downward, rounded phosphate pebbles up to $3 \mathrm{~cm}$ in diameter at base; dark brownish gray (5YR 2/1) grading downward at about $15 \mathrm{ft}$ to olive brown $(5 Y 3 / 4)$.

UNCONFORMITY

\section{Harleyville Formation, Osborn Member}

Calcarenite, fine to medium, grayish-yellow (5Y 7/4); composed of foraminifera tests and shell hash.....

Calcarenite, fine; composed mostly of foraminifera tests; light olive brown $(5 Y 5 / 4)$ grading downward by $24 \mathrm{ft}$ to light grayish olive (10Y 5/2); impenetrable lithified layer at base.

Base of Wicomico formation:

$+59 \mathrm{ft}$ above sea level

\section{Bottomed in Harleyville Formation, Osborn Member}


HV-4: $2.05 \mathrm{mi}$ west of eastern quadrangle border, $1.55 \mathrm{mi}$ south of northern quadrangle border, in northeast 1/9th of the quadrangle (latitude $33.2281^{\circ}$ N., longitude $80.4104^{\circ} \mathrm{W}$.). Surface elevation $79 \mathrm{ft}$.

\section{LITHOLOGY}

DEPTH, IN FEET

\section{Wicomico formation}

Sand, fine to very coarse, very poorly sorted, silty, clayey; dusky brown $(10 Y R 2 / 2)$ grading downward through moderate olive brown (5Y 4/4)

to dark yellowish orange (10YR 6/6) and mottled light brownish gray

$(5 Y R 6 / 1)$.

Sand, fine to very coarse, very poorly sorted, silty, much more clayey

than above; dark yellowish orange (10YR 6/6) and mottled reddish

orange (10R 5/6); difficult augering .....

Sand, very fine to coarse, somewhat better sorted than above, reddish

orange (10R 5/6); yellowish-gray (5Y 8/1), clayey sand layers

interspersed throughout

Sand, fine to very coarse, very poorly sorted, subangular, clayey, silty, light-brown $(5 Y R$ 5/6)....

Sand, very fine to medium, better sorted than above, more silty and less clayey than above, very-dark-yellowish-orange (10YR 5/6)......

\section{UNCONFORMITY}

\section{Ashley Formation, Runnymede Marl Member}

Calcarenite, quartzose and phosphatic, subangular to subrounded phosphate pebbles, grayish-yellow (5Y 8/4) limestone pebbles; sand dollar fragment in basal $1 \mathrm{ft}$; light olive brown $(5 Y 5 / 4)$

\section{UNCONFORMITY}

\section{Tupelo Bay Formation, Pregnall Member}

Calcarenite, fine to medium grading rapidly downward to very fine to fine at base; grayish yellow $(5 Y 8 / 4)$ grading downward to very pale orange (10YR 8/2) at base; bottomed on impenetrable limestone layer

Base of Wicomico formation:

Base of Ashley Formation, Runnymede Marl Member

\section{Bottomed in Tupelo Bay Formation, Pregnall Member}




\section{Jacksonville Quadrangle}

JB-1: $0.7 \mathrm{mi}$ west of eastern quadrangle border, $1.35 \mathrm{mi}$ south of northern quadrangle border, in northeast 1/9th of the quadrangle (latitude $32.8554^{\circ}$ N., longitude $80.3866^{\circ} \mathrm{W}$.). Surface elevation $19 \mathrm{ft}$.

LITHOLOGY

DEPTH, IN FEET

Wando Formation, upper member

Sand, medium to very coarse, poorly sorted, angular; fine, dark heavymineral grains abundant; dusky brown $(5 Y R 2 / 2)$ grading downward through dark yellowish orange $(10 Y R 6 / 6)(0.5-1.0 \mathrm{ft})$ and pale orange $(10 Y R 7 / 2)(1-6 \mathrm{ft})$ to grayish orange (10YR 7/4); hit hard object at

$24 \mathrm{ft}$ but not recovered, apparently pushed aside.

\section{UNCONFORMITY}

\section{Ten Mile Hill Formation}

Sand, fine to coarse, poorly sorted, somewhat more rounded than above, slightly silty; medium olive gray $(5 Y 5 / 1)$ grading downward by $31 \mathrm{ft}$ to dark olive gray $(5 Y 3 / 1)$. 24-39

UNCONFORMITY

\section{Harleyville Formation, Osborn Member}

Calcarenite, fine, silty, no quartz or phosphate; grayish yellow (5Y 7/4) grading downward through yellowish gray $(5 Y 6 / 2)$ to light olive brown $(5 Y 5 / 4)$ by $76 \mathrm{ft}$ $39-101$

Base of Wando Formation, upper member:

$-5 \mathrm{ft}$ below sea level Base of Ten Mile Hill Formation: $-20 \mathrm{ft}$ below sea level

\section{Bottomed in Harleyville Formation, Osborn Member}


JB-2: $1.45 \mathrm{mi}$ west of eastern quadrangle border, $3.85 \mathrm{mi}$ south of northern quadrangle border, in east-central $1 / 9$ th of the quadrangle (latitude $32.8193^{\circ} \mathrm{N}$., longitude $80.3997^{\circ}$ W.). Surface elevation $15 \mathrm{ft}$.

\section{LITHOLOGY}

DEPTH, IN FEET

\section{Wando Formation, upper member}

Sand, medium, pale-red (10R 6/2); contains scattered fine, dark heavymineral grains

Sand, medium to very coarse, poorly sorted, subrounded; contains scattered fine, dark heavy-mineral grains; moderate brown (5YR 6/6) grading downward through pale yellowish brown $(10 Y R 6 / 2)$ to dark yellowish orange (10YR 6/6); grades downward to

Sand, medium to very coarse, poorly sorted, subrounded, silty; contains scattered fine, dark heavy-mineral grains; lumps of indurated marl up to $2 \mathrm{~cm}$ in diameter at base; yellowish gray $(5 Y 6 / 2)$ grading downward to light olive gray $(5 Y 5 / 2)$.

\section{Harleyville Formation, Osborn Member}

Calcarenite, fine, silty; grayish yellow (5Y7/4) grading downward by $25 \mathrm{ft}$ to yellowish gray $(5 Y 6 / 2)$

Base of Wando Formation, upper member:

Bottomed in Harleyville Formation, Osborn Member 
JB-3: $1.35 \mathrm{mi}$ west of eastern quadrangle border, $1.85 \mathrm{mi}$ north of southern quadrangle border, in southeast 1/9th of the quadrangle (latitude $32.7766^{\circ} \mathrm{N}$., longitude $80.3978^{\circ} \mathrm{W}$.). Surface elevation $13 \mathrm{ft}$.

LITHOLOGY

DEPTH, IN FEET

Road fill, clayey sand $0-1$

-UNCONFORMITY

\section{Wando Formation, upper member}

Sand, fine, clayey and silty, stiff; dusky brown $(5 Y R 2 / 2)$ grading rapidly downward to dark brownish gray $(5 Y R 3 / 1)$.....

Sand, fine, silty, soft, yellowish-brown (10YR 5/2); contains sparse medium to coarse grains

Sand, fine, clayey, silty, stem or root fragments near base; olive gray $(5 Y 4 / 2)$ grading downward to medium bluish gray $(5 B 5 / 1)$

\section{UNCONFORMITY}

\section{Ten Mile Hill Formation}

Sand, fine to coarse, poorly sorted, dominantly subangular but with some subrounded grains as well; rounded phosphate lumps up to $2.5 \mathrm{~cm}$ on basal contact; olive gray $(5 Y 3 / 2)$ grading downward around $14 \mathrm{ft}$ to olive gray (5Y 5/1).

\section{UNCONFORMITY}

\section{Ashley Formation, Runnymede Marl Member}

Calcarenite, fine, slightly quartzose and phosphatic, sparsely shelly, moderate-olive-brown (5Y 4/4); large foraminifera tests abundant; rounded phosphate granules abundant in basal $1 \mathrm{ft}$

-UNCONFORMITY

\section{Harleyville Formation, Osborn Member}

Calcarenite, fine, silty, yellowish-gray ( $5 Y 6 / 2)$; no quartz or phosphate grains; indurated lumps in upper $1 \mathrm{ft}$.

Base of Wando Formation, upper member:

Base of Ten Mile Hill Formation:

Base of Ashley Formation, Runnymede Marl Member:

Bottomed in Harleyville Formation, Osborn Member
$+3 \mathrm{ft}$ above sea level

$-11 \mathrm{ft}$ below sea level

$-17 \mathrm{ft}$ below sea level 
JB-4: $3.5 \mathrm{mi}$ west of eastern quadrangle border, $0.1 \mathrm{mi}$ north of southern quadrangle border, in south-central 1/9th of the quadrangle (latitude $32.7523^{\circ}$ N., longitude $80.4349^{\circ}$ W.). Surface elevation $7 \mathrm{ft}$.

\section{LITHOLOGY}

DEPTH, IN FEET

\section{Wando Formation, upper member}

Sand, dominantly medium but fine to coarse, poorly sorted, subangular to subrounded, more subrounded downward; orange and black heavymineral grains present below $1 \mathrm{ft}$; slightly micaceous toward base; quartz granules and black $(N 1)$ phosphate pebbles abundant in basal $1 \mathrm{ft}$; dark yellowish orange (10YR 6/6) grading downward through pale orange $(10 Y R 7 / 2)$ to light olive gray $(5 Y 5 / 1)$...

\section{Edisto Formation}

Sand, fine, very calcareous and phosphatic; light olive gray (5Y 5/1) grading downward to light olive gray $(5 Y 6 / 1)$

\section{UNCONFORMITY}

\section{Ashley Formation, Givhans Ferry Member}

Sand, fine, calcareous, moderate-olive-brown (5Y 4/4).

Indurated bed; very tough drilling; no recovery

\section{UNCONFORMITY}

\section{Ashley Formation, Runnymede Marl Member}

Calcarenite, fine, increasingly clayey and silty downward; sand-size foraminifera tests very abundant; moderate olive brown $(5 Y 4 / 4)$ grading downward by $56 \mathrm{ft}$ to light olive brown (5Y 5/4)

Calcarenite, medium to coarse, quartzose and phosphatic, light-olive-

brown (5Y 5/4); contains scattered tooth fragments $77-79$ UNCONFORMITY-

\section{Parkers Ferry Formation}

Calcilutite, dense, sticky, light-grayish-olive (10Y 5/2).

Base of Wando Formation, upper member:

Base of Edisto Formation:

Base of Ashley Formation, Givhans Ferry Member: Base of Ashley Formation, Runnymede Marl Member:

\section{Bottomed in Parkers Ferry Formation}

$-2 \mathrm{ft}$ below sea level

$-8 \mathrm{ft}$ below sea level

$-16 \mathrm{ft}$ below sea level

$-72 \mathrm{ft}$ below sea level 
JB-5: $1.95 \mathrm{mi}$ east of western quadrangle border, $4.4 \mathrm{mi}$ south of northern quadrangle border, in west-central 1/9th of the quadrangle (latitude $32.8113^{\circ} \mathrm{N}$., longitude $80.4662^{\circ} \mathrm{W}$.). Surface elevation $24 \mathrm{ft}$.

LITHOLOGY

DEPTH, IN FEET

Road fill, limestone gravel and coarse sand.

$0-1$

-UNCONFORMITY

\section{Ten Mile Hill Formation}

Sand, fine, well-sorted, upper $2 \mathrm{ft}$ very clayey and silty, slightly micaceous; olive black (5Y3/1) and mottled greenish gray $(5 G 6 / 1)$

grading downward at about $4 \mathrm{ft}$ to medium yellowish gray $(5 Y 7 / 1)$.

Sand, fine, well-sorted, silty, micaceous; greenish gray (5GY 6/1) and mottled grayish orange (10YR 6/4)

Clay, dense, greasy, sticky; greenish gray $(5 G 6 / 1)$ and mottled greenish gray $(5 G Y$ 6/1) grading downward at $11 \mathrm{ft}$ to medium dark gray $(N 4)$

Sand, fine to very coarse, very poorly sorted, very silty and clayey, greenish-gray $(5 G 6 / 1)$; contains abundant rounded but lumpy and rough-surfaced black $(N 1)$ phosphate pebbles up to $6 \mathrm{~cm}$ in diameter

-UNCONFORMITY-

\section{Ashley Formation, Runnymede Marl Member}

Sand, fine, silty, very calcareous, olive (10Y 6/6)

Sand, dominantly fine but coarsens downward to fine to medium, silty, clayey, very calcareous, glauconitic, olive (10Y 6/6); large foraminifera tests visible

Sand, fine to very coarse, very poorly sorted, very calcareous and phosphatic; contains coarse to very coarse polished quartz grains and abundant black $(N 1)$ phosphate and calcite-cemented pebbles up to $5 \mathrm{~cm}$ in diameter; light yellowish gray $(5 Y 6 / 2)$ grading downward to moderate olive gray $(5 Y 4 / 2)$

-UNCONFORMITY

\section{Harleyville Formation, Osborn Member}

Calcarenite, fine, mostly soft; mostly composed of foraminifera tests; light grayish olive (10Y 5/2) grading downward to moderate greenish yellow $(10 Y 7 / 3)$

Calcarenite, fine, silty, mostly soft, pale-olive (10Y 6/4); mostly

composed of foraminifera tests.

Calcarenite, medium to coarse, glauconitic, olive (10Y 5/2); black ( $N 1)$

phosphate granules and shell fragments abundant 


\section{Parkers Ferry Formation}

Calcilutite, dense, tough, medium-greenish-gray ( $5 G 5 / 1)$; burrowed

from above in top $0.5 \mathrm{ft}$; hard to cut off stems.

$100-106$

Base of Ten Mile Hill Formation:

Base of Ashley Formation, Runnymede Marl Member:

Base of Harleyville Formation, Osborn Member:

+9 ft above sea level

$-23 \mathrm{ft}$ below sea level

$-76 \mathrm{ft}$ below sea level

Bottomed in Parkers Ferry Formation 
JB-6: $2.05 \mathrm{mi}$ east of western quadrangle border, $0.9 \mathrm{mi}$ south of northern quadrangle border, in northwest 1/9th of the quadrangle (latitude $32.8619^{\circ}$ N., longitude $80.4640^{\circ}$ W.). Surface elevation $29 \mathrm{ft}$.

\section{LITHOLOGY}

DEPTH, IN FEET

\section{Ten Mile Hill Formation}

Sand, dominantly fine with scattered grains up to coarse, silty, clayey, dark-yellowish-orange (10YR 6/6).

Sand, fine, clayey, silty, stiff; reddish brown (10YR 5/6) grading downward to yellowish gray $(5 Y 7 / 2)$

Clay, sandy (fine), stiff, waxy, micaceous, yellowish-gray (5Y 7/2)

Sand, fine to coarse, poorly sorted, clean, very-pale-yellowish-brown $(10 Y R 7 / 2)$

Sand, medium to coarse; rounded pebbles up to $5 \mathrm{~cm}$ in diameter near base composed of quartz, phosphate, and calcite-cemented lumps; yellowish gray (5Y 8/1) streaked light grayish orange (10YR 8/4)

\section{UNCONFORMITY}

\section{Parachucla Shale equivalent}

Sand, fine; dark yellowish orange (10YR 6/6) grading downward to yellowish brown (10YR 5/2)

-UNCONFORMITY

\section{Edisto Formation}

Calcarenite, quartzose, phosphatic, sparsely shelly; grayish yellow (5Y 7/4) grading downward to pale olive gray $(5 Y 6 / 2)$.

Sand, fine, well-sorted, very calcareous, pale-olive-gray ( $5 Y 6 / 2)$; contains scattered shell fragments; calcite-cemented hard intervals at $23 \mathrm{ft}$ and $28 \mathrm{ft}$

\section{UNCONFORMITY}

\section{Ashley Formation, Runnymede Marl Member}

Calcarenite, silty, denser than above, quartzose, moderate-olive-brown (5Y 4/4); contains scattered mica flakes

Calcarenite, silty, quartzose, glauconitic, phosphatic, grayish-olive (10Y 4/2); quartz and phosphate granules in basal $1 \mathrm{ft}$ along with some small shark teeth... 
Harleyville Formation, Osborn Member

Calcarenite, fine, soft, grainy, olive (10Y 5/2); occasional calcite-

cemented lumps; easy drilling ..... $49-111$

Base of Ten Mile Hill Formation:

Base of Parachucla Shale:

Base of Edisto Formation:

Base of Ashley Formation, Runnymede Marl Member:
$+12 \mathrm{ft}$ above sea level $+10 \mathrm{ft}$ above sea level $-7 \mathrm{ft}$ below sea level $-20 \mathrm{ft}$ below sea level

Bottomed in Harleyville Formation, Osborn Member 
JB-7: $2.9 \mathrm{mi}$ west of eastern quadrangle border, $0.7 \mathrm{mi}$ south of northern quadrangle border, in north-central 1/9th of the quadrangle (latitude $32.8651^{\circ}$ N., longitude $80.4243^{\circ}$ W.). Surface elevation $22 \mathrm{ft}$.

LITHOLOGY

DEPTH, IN FEET

Road fill, sand. $0-1$

UNCONFORMITY-

\section{Edisto River floodplain sediment}

Sand, fine, silty, clayey, micaceous; olive gray (5Y 4/1) grading downward through dark yellowish orange $(10 Y R$ 6/6) and mottled olive $(10 Y 5 / 2)(1-4 \mathrm{ft})$ to all olive $(10 Y 5 / 2)$

\section{UNCONFORMITY}

\section{Marks Head Formation}

Sand, fine, well-sorted; fine, dark heavy-mineral grains moderately abundant; yellowish gray $(5 Y 7 / 2)$ grading downward through olive brown $(5 Y 3 / 4)(9-13 \mathrm{ft})$, and through grayish yellow $(5 Y 6 / 2)$

(13-18 ft) to light olive brown ( $5 Y 5 / 4)$; grades downward to

Sand, fine to medium, glauconitic, phosphatic, grayish-olive (10Y 4/2); contains shark and fish teeth; black $(N 1)$ rounded phosphate pebbles up to $5 \mathrm{~cm}$ in diameter present in basal $1 \mathrm{ft}$.

UNCONFORMITY

\section{Harleyville Formation, Osborn Member}

Calcarenite, grainy, soft; pale olive (10Y6/2) in upper $1 \mathrm{ft}$ but grading rapidly downward to yellowish gray $(5 Y 6 / 2)$...... $31-41$

Base of Edisto River floodplain sediment:

Base of Marks Head Formation:

$+16 \mathrm{ft}$ above sea level -9 ft below sea level

\section{Bottomed in Harleyville Formation, Osborn Member}


JB-8: $3.6 \mathrm{mi}$ west of eastern quadrangle border, $3.4 \mathrm{mi}$ north of southern quadrangle border, in central 1/9th of the quadrangle (latitude $32.8000^{\circ} \mathrm{N}$., longitude $80.4363^{\circ} \mathrm{W}$.). Surface elevation $13 \mathrm{ft}$.

LITHOLOGY

DEPTH, IN FEET

Road fill, limestone gravel and coarse sand.

$0-2$

-UNCONFORMITY

\section{Edisto River floodplain sediment}

Clay, greasy, smooth; dark olive gray $(5 Y 2 / 2)$ grading downward by

$2.5 \mathrm{ft}$ to olive $(10 Y 5 / 2)$. 2-6

Sand, fine to coarse, poorly sorted, silty, soft, grayish-yellow (5Y 7/4). $6-12$ -UNCONFORMITY-

\section{Edisto Formation}

Sand, fine, slightly silty and clayey, dense; yellowish gray (5Y 7/2) grading downward to dusky yellow (5Y 6/4) $12-16$

-UNCONFORMITY

\section{Ashley Formation, Runnymede Marl Member}

Calcarenite, fine, slightly silty and clayey, light-olive-brown (5Y 5/4);

contains scattered large foraminifera tests; grades downward to.. $16-31$

Sand, fine to medium, calcareous, phosphatic, grayish-olive $(10 Y 4 / 2)$. $31-36$

-UNCONFORMITY

\section{Harleyville Formation, Osborn Member}

Calcarenite, fine, grainy, sparsely shelly, pale-olive (10Y 6/2) $36-46$

Base of Edisto River floodplain sediment:

Base of Edisto Formation:

Base of Ashley Formation, Runnymede Marl Member:

$+\mathbf{f t}$ above sea level $-3 \mathrm{ft}$ below sea level $-23 \mathrm{ft}$ below sea level

\section{Bottomed in Harleyville Formation, Osborn Member}


JB-9: $0.65 \mathrm{mi}$ west of eastern quadrangle border, $0.15 \mathrm{mi}$ south of northern quadrangle border, in northeast $1 / 9$ th of the quadrangle (latitude $32.8730^{\circ} \mathrm{N}$., longitude $80.3858^{\circ}$ W.). Surface elevation $18 \mathrm{ft}$.

\section{LITHOLOGY}

DEPTH, IN FEET

\section{Wando Formation, upper member}

Sand, fine to very coarse, very poorly sorted, clean, grayish-orange (10YR 7/4). $0-1$

Sand, fine to very coarse, very poorly sorted, clean, thixotropic; contains about 1 percent fine to medium, dark heavy-mineral grains; yellowish orange $(10 Y R 7 / 6)$ grading downward through very pale orange $(10 Y R 8 / 2)$ to pale grayish orange $(10 Y R 8 / 4)$....

Sand, fine to very coarse, very poorly sorted, clean, thixotropic; contains about 1 percent fine to medium, dark heavy-mineral grains; quartz pebbles up to $3 \mathrm{~cm}$ in diameter present below $9 \mathrm{ft}$; pale yellowish brown $(10 Y R 6 / 2)$ grading downward through moderate yellowish brown $(10 Y R 5 / 2)$ to moderate yellowish brown $(10 Y R 5 / 4)$

\section{Harleyville Formation, Osborn Member}

Calcarenite, fine, grainy, a few intervals somewhat silty, soft, pale-

olive (10Y6/2); composed mostly of foraminifera tests

Base of Wando Formation, upper member:

+1 ft above sea level

\section{Bottomed in Harleyville Formation, Osborn Member}


JB-10: $1.25 \mathrm{mi}$ east of western quadrangle border, $0.75 \mathrm{mi}$ north of southern quadrangle border, in southwest 1/9th of the quadrangle (latitude $32.7610^{\circ}$ N., longitude $80.4785^{\circ} \mathrm{W}$.). Surface elevation $14 \mathrm{ft}$.

LITHOLOGY

DEPTH, IN FEET

Road fill, fine, clayey, varicolored sand

$0-6$

-UNCONFORMITY

\section{Wando Formation, upper member}

Sand, dominantly fine but up to coarse and rounded, silty, sparsely micaceous near base; very fine, dark heavy-mineral grains abundant; grayish yellow (5Y7/4) grading downward at $14 \mathrm{ft}$ to medium bluish gray $(5 B 5 / 1)$ $6-17$

Clay, greasy, increasingly sandy downward, medium-bluish-gray $(5 B 5 / 1)$

Sand, fine to coarse, clayey, silty, medium-bluish-gray ( $5 B \mathrm{~B} / 1)$;

contains rounded but rough-surfaced black $(N 1)$ phosphate lumps up to

$4 \mathrm{~cm}$ in diameter.

-UNCONFORMITY-

\section{Marks Head Formation}

Silt, clayey, sandy (very fine), cheesy texture; very fine mica flakes abundant; contains thin laminae of very fine sand; abundant phosphate granules in basal $1 \mathrm{ft}$; olive brown ( $5 Y 3 / 4)$ to medium olive gray $(5 Y 4 / 2)$

\section{UNCONFORMITY}

\section{Edisto Formation}

Calcarenite, fine, quartzose and phosphatic, calcitic silty, very-lightolive-gray $(5 Y 7 / 1)$; semilithified at top; fragments of thick oyster shells on basal contact (probably Ostrea haitensis). $31-37$

\section{UNCONFORMITY}

\section{Ashley Formation, Runnymede Marl Member}

Sand, fine, well-sorted, silty, very calcareous and phosphatic, shelly, light-grayish-olive ( $10 Y 5 / 2)$; contains large foraminifera tests; crunched through several hard beds in this interval; grades downward to.

Sand, fine to medium, subangular to subrounded, very silty, very calcareous and phosphatic, light-olive-brown ( 5 Y 5/4)

Sand, medium to coarse, very phosphatic and glauconitic; black ( $N 1)$ pebbles up to $3 \mathrm{~cm}$ in diameter abundant; no color recorded; probably stopped at or near basal contact. $75-76$

Base of Wando Formation, upper member:

Base of Marks Head Formation:

Base of Edisto Formation:

Base of Ashley Formation, Runnymede Marl Member:
-8 ft below sea level

-17 ft below sea level

$-23 \mathrm{ft}$ below sea level -62(?) ft below sea level

Bottomed near or on top of Harleyville Formation, Osborn Member (?) 


\section{James Island Quadrangle}

JA-1: $3.35 \mathrm{mi}$ west of eastern quadrangle border, $2.45 \mathrm{mi}$ north of southern quadrangle border, in south-central 1/9th of the quadrangle (latitude $32.6608^{\circ} \mathrm{N}$., longitude $79.9323^{\circ} \mathrm{W}$.). Surface elevation $12 \mathrm{ft}$.

\section{LITHOLOGY}

DEPTH, IN FEET

\section{Holocene beach sand}

Sand, fine, well-sorted, clean; very fine, dark heavy-mineral grains abundant; pale brown (5YR 5/2) grading downward through medium yellowish orange $(10 Y R$ 7/6) $(0.5-3.0 \mathrm{ft})$ and through yellowish gray $(5 Y 7 / 2)(3-6 \mathrm{ft})$ to greenish gray $(5 G 5 / 1)$

Sand, fine, well-sorted, clean, greenish-gray ( $5 G 5 / 1)$; Mulinia shell fragments abundant; very fine, dark heavy-mineral grains abundant; finely micaceous below $15 \mathrm{ft}$

Silt, clayey, greasy, dark-greenish-gray $(5 G 4 / 1)$; fulsome odor present

Sand, fine but with a minor medium to coarse fraction, silty, shelly, dark-greenish-gray $(5 G 4 / 1)$; grades downward to......

Sand, medium to coarse, slightly silty, sparsely shelly, dark-greenishgray $(5 G 4 / 1)$; contains rounded quartz granules; wood fragment and clay lumps from unit below on basal contact.

Silt, sandy (very fine), micaceous; contains abundant roots; greenish gray $(5 G Y 5 / 1)$ grading downward to medium olive gray $(5 Y 4 / 2)$

Sand, fine to medium, medium-olive-gray ( $5 Y 4 / 2)$; contains lumps of Ashley lithology and phosphate.

\section{UNCONFORMITY}

\section{Marks Head Formation}

Sand, fine, silty, dense, micaceous; basal $1 \mathrm{ft}$ contains rounded lumps of Ashley lithology up to $2 \mathrm{~cm}$ in diameter and rounded lumps of black $(N 1)$ phosphate up to $5 \mathrm{~cm}$ in diameter; moderate olive brown (5Y3/4) grading downward to dark olive brown (5Y2/4).

\section{UNCONFORMITY}

\section{Parkers Ferry Formation}

Calcilutite, no quartz or phosphate; strong hydrogen sulfide odor present; light grayish olive (10Y 5/2) grading downward through pale olive (10Y6/2) back to light grayish olive $(10 Y 5 / 2)$.

Base of Holocene beach sand:

Base of Marks Head Formation:

\section{Bottomed in Parkers Ferry Formation}


JA-2: $1.85 \mathrm{mi}$ east of western quadrangle border, $1.05 \mathrm{mi}$ north of southern quadrangle border, in southwest 1/9th of the quadrangle (latitude $32.6414^{\circ}$ N., longitude $79.9680^{\circ}$ W.). Surface elevation $7 \mathrm{ft}$.

\section{LITHOLOGY}

DEPTH, IN FEET

Road fill, limestone gravel

$0-0.5$

-UNCONFORMITY

\section{Holocene beach sand}

Sand, fine, slightly micaceous, dark-yellowish-brown (10YR 4/4). $0.5-1.0$

Sand, fine, well-sorted, clean, yellowish-gray ( $5 Y 7 / 2)$; very fine, dark heavy-mineral grains abundant.

Sand, fine, well-sorted, clean, sparsely shelly (6-23 ft, $27-33 \mathrm{ft}$ ) to very

shelly, thixotropic, grayish-olive (10Y 4/2); basal $1 \mathrm{ft}$ silty; very fine,

dark heavy-mineral grains abundant.

Silt, clayey, sandy (very fine), finely micaceous, very-dark-greenishgray (5GY 3/1); basal $1 \mathrm{ft}$ grayish olive (10Y 4/2) and contains wood fragments

\section{UNCONFORMITY}

\section{Wando Formation, middle member}

Sand, very fine to fine, silty, clayey, sparsely micaceous, sparsely

shelly, dark-greenish-gray $(5 G 4 / 1)$; grades downward to

Silt, sandy (very fine), clayey, sparsely micaceous, dark-greenish-gray

( $5 G 4 / 1)$; grades downward to

Sand, fine to coarse, poorly sorted, medium-gray (N 5); lumps of marl in basal $2 \mathrm{ft}$ and rounded black $(N 1)$ phosphate pebbles up to $1 \mathrm{~cm}$ in diameter

\section{UNCONFORMITY}

\section{Parkers Ferry Formation}

Calcisiltite to very fine calcarenite, no quartz or phosphate, light-olive

Base of Holocene beach sand:

Base of Wando Formation, middle member:

\section{Bottomed in Parkers Ferry Formation}


JA-3: $1.0 \mathrm{mi}$ west of eastern quadrangle border, $3.85 \mathrm{mi}$ north of southern quadrangle border, in east-central 1/9th of the quadrangle (latitude $32.6816^{\circ}$ N., longitude $79.8915^{\circ}$ W.). Surface elevation $9 \mathrm{ft}$.

LITHOLOGY

DEPTH, IN FEET

Disturbed soil containing scattered limestone gravel

$0-0.5$

-UNCONFORMITY

\section{Holocene beach sand}

Sand, fine, well-sorted, clean, thixotropic; very fine, dark heavy-

mineral grains abundant; dusky brown $(5 Y R 2 / 2)$ grading downward

through light yellowish brown (10YR 6/4) (1-3 ft) and through

moderate brown (5YR 3/4) (3-4 ft) back through light yellowish brown

$(10 Y R$ 6/4) (4-6 ft) to olive gray $(5 Y 4 / 1)$.

Silt, clayey, sandy (very fine), finely micaceous, moderate-greenishgray $(5 G Y 3 / 1)$; oyster fragments present.

Sand, very fine, silty, soft, moderate-greenish-gray (5GY 3/1); grades

downward to ......

Sand, very fine grading downward to fine, silty, soft, moderategreenish-gray ( $5 G Y 3 / 1)$; very fine, dark heavy-mineral grains abundant; sparsely shelly; grades downward to.

Sand, fine, less silty than above, soft, moderate-greenish-gray

(5GY 3/1); very fine, dark heavy-mineral grains less common than

above; fulsome odor present

Sand, fine, well-sorted, very shelly, medium-olive-gray ( $5 Y 5 / 1)$;

diverse fauna but dominated by Mulinia; basal $1 \mathrm{ft}$ has fine to medium

quartz sand and fine, rounded phosphate sand.

\section{UNCONFORMITY}

\section{Wando Formation, middle member}

Silt, dense, clayey, sticky, finely micaceous, dark-olive-gray (5Y 3/1)

Sand, fine, well-sorted, silty, dark-olive-gray (5Y 3/1); lumps of rounded marl up to $3 \mathrm{~cm}$ in diameter in basal $1 \mathrm{ft}$. $76-85$

-UNCONFORMITY

\section{Ashley Formation, Runnymede Marl Member}

Calcarenite, fine, phosphatic, light-olive-brown (5Y 5/4); contains very

large coiled foraminifera tests

Base of Holocene beach sand:

Base of Wando Formation, middle member:

$-40 \mathrm{ft}$ below sea level

$-76 \mathrm{ft}$ below sea level

\section{Bottomed in Ashley Formation, Runnymede Marl Member}


JA-4: $3.5 \mathrm{mi}$ east of western quadrangle border, $3.15 \mathrm{mi}$ south of northern quadrangle border, in central 1/9th of the quadrangle (latitude $32.7043^{\circ}$ N., longitude $79.9397^{\circ} \mathrm{W}$.). Surface elevation $9 \mathrm{ft}$.

\section{LITHOLOGY}

DEPTH, IN FEET

\section{Silver Bluff beds}

Sand, fine, well-sorted, clean, moderate-brown (5YR 3/4); contains oyster fragments

Sand, dominantly fine with a minor rounded medium to coarse quartz fraction, sparsely micaceous; very fine to fine, dark heavy-mineral grains abundant; grayish orange (10YR 7/4) grading downward to dark yellowish orange (10YR 6/6)

Sand, fine, silty, coarsely micaceous; very fine to fine, dark heavymineral grains abundant; dark yellowish orange (10YR 6/6) grading downward to pale yellowish brown (10YR 5/4).

Sand, fine, grayish-yellow ( $5 Y 8 / 4)$; very fine to fine, dark heavymineral grains abundant; shell fragments present.

Sand, mostly fine but ranges up to coarse, yellowish-gray (5Y 7/2); contains carbonate-cemented lumps and phosphate granules; shell fragments abundant...... $16-20$

\section{-UNCONFORMITY}

\section{Wando Formation, upper member}

Silt, clayey, sticky, sandy (very fine), micaceous, dark-greenish-gray $(5 G Y 4 / 1)$

Sand, fine, silty; very fine, dark heavy-mineral grains present; shell fragments abundant, mostly Mulinia at top but fauna gets more diverse downward including oyster, Oliva, Dinocardium, Noetia, Anadara ovalis, A. brasiliana; dark greenish gray (5GY 4/1) grading downward to medium greenish gray $(5 G 5 / 1)$.

\section{Goose Creek Limestone}

Sand, medium, very calcareous and phosphatic, medium-olive-gray (5Y 5/1); calcite-cemented lumps abundant

Sandstone, medium grading downward to medium to coarse, very phosphatic, calcite-cemented, medium-olive-gray (5Y 5/1); tough drilling .

\section{UNCONFORMITY}

\section{Marks Head Formation}

Sand, fine (quartz) to medium (phosphate), moderate-olive-brown

(5Y 4/4), grades rapidly downward to sand and olive-brown (5Y3/6)

clay interbedded at centimeter scale; grades downward to......

Sand, fine to medium, clayey, moderate-olive-brown (5Y 4/6); rounded phosphate pebbles up to $1 \mathrm{~cm}$ in diameter and shell hash at base. 
Ashley Formation, Runnymede Marl Member

Calcarenite, fine, moderate-olive-brown ( $5 Y 4 / 4)$; foraminifera tests

abundant; quartz and phosphate sand abundant near base. $67-81$

Base of Silver Bluff beds:

Base of Wando Formation, upper member:

Base of Goose Creek Limestone:

Base of Marks Head Formation:

$-11 \mathrm{ft}$ below sea level

$-34 \mathrm{ft}$ below sea level

$-\mathbf{4 0} \mathrm{ft}$ below sea level

Bottomed in Ashley Formation, Runnymede Marl Member 
JA-5: $1.05 \mathrm{mi}$ east of western quadrangle border, $4.05 \mathrm{mi}$ south of northern quadrangle border, in west-central 1/9th of the quadrangle (latitude $32.6915^{\circ}$ N., longitude $79.9816^{\circ}$ W.). Surface elevation $7 \mathrm{ft}$.

\section{LITHOLOGY}

DEPTH, IN FEET

\section{Silver Bluff beds}

Sand, fine, well-sorted, clean, finely micaceous; dark yellowish brown

$(10 Y R 4 / 2)$ grading downward to pale olive gray $(5 Y 6 / 2)$

Sand, fine, rounded bimodal coarse fraction appears at $6 \mathrm{ft}$, micaceous; very fine, dark heavy-mineral grains abundant; bright orange (10YR 5/6) grading downward through yellowish orange (10YR 7/6)

$(1-11 \mathrm{ft})$ to greenish gray $(5 G Y 6 / 1) \ldots$

Sand, medium to very coarse, poorly sorted, rounded, dark-greenishgray $(5 G Y 4 / 1)$; very shelly with diverse molluscan fauna plus sand dollar fragments.

Peat, dusky-brown (5YR 2/2) $13-14$

-UNCONFORMITY

\section{Wando Formation, upper member}

Silt, sandy (very fine), clayey, dark-greenish-gray $(5 G 4 / 1)$. $14-16$

Clay, silty, sandy (very fine), sticky, micaceous, dark-greenish-gray $(5 G 4 / 1)$

Sand, fine, silty, dark-greenish-gray ( $5 G 4 / 1)$; very fine to fine, dark heavy-mineral grains moderately abundant; shelly, including Mulinia, Oliva, and oyster. $27-35$

Silt, clayey, dark-greenish-gray $(5 G 4 / 1)$

Sand, fine, dark-greenish-gray $(5 G 4 / 1)$; very fine to fine, dark heavymineral grains moderately abundant; abundant oyster shells

Sand, medium to very coarse, poorly sorted, medium-greenish-gray (5GY 5/1); contains diverse mollusk shell fragments and phosphate pebbles up to $1 \mathrm{~cm}$ in diameter.

\section{-UNCONFORMITY}

\section{Marks Head Formation}

Sand, fine to medium grading downward to medium to coarse, grains very rounded and polished, moderate-olive-brown (5Y 4/4); phosphatic and contains foraminifera tests in upper part. 


\section{Parkers Ferry Formation}

Calcisiltite, clayey, sticky, light-grayish-olive (10Y 5/2); foraminifera tests moderately abundant; hard layer at $72 \mathrm{ft}$; NP 19/20 nannofossils assemblage at $60 \mathrm{ft}$

Base of Silver Bluff beds:

Base of Wando Formation, upper member:

Base of Marks Head Formation:

$-7 \mathrm{ft}$ below sea level $-38 \mathrm{ft}$ below sea level $-\mathbf{4 4} \mathrm{ft}$ below sea level

Bottomed in Parkers Ferry Formation 
JA-6: $3.6 \mathrm{mi}$ west of eastern quadrangle border, $1.5 \mathrm{mi}$ south of northern quadrangle border, in north-central 1/9th of the quadrangle (latitude $32.7288^{\circ}$ N., longitude $79.9360^{\circ} \mathrm{W}$.). Surface elevation $13 \mathrm{ft}$.

\section{LITHOLOGY}

DEPTH, IN FEET

\section{Wando Formation, upper member}

Sand, fine, well-sorted, clean; very fine, dark heavy-mineral grains abundant; grayish brown (5YR 3/2) grading downward to pale olive brown $(5 Y 6 / 6)$.

Sand, fine to medium, thixotropic; very fine, dark heavy-mineral grains present but not abundant; dark yellowish orange (10YR 6/6) grading downward to pale olive gray $(5 Y 6 / 2)$

Silt, clayey, sandy (very fine), medium-greenish-gray (5GY 7/2)

Sand, fine, well-sorted, micaceous; light olive gray ( $5 Y 5 / 2)$ grading downward through dark yellowish brown $(10 Y R$ 4/6) $(10-11 \mathrm{ft})$ to medium greenish gray $(5 G 5 / 1)$

Sand, fine, well-sorted, micaceous, greenish-black ( $5 G 2 / 1)$; contains

shell fragments.

Silt, sandy (very fine), dense, sticky, finely micaceous, mediumgreenish-gray $(5 G 5 / 1)$

Sand, fine, silty, shelly, medium-greenish-gray ( $5 G 5 / 1)$

Silt, sandy (very fine), dense, sticky, finely micaceous, mediumgreenish-gray $(5 G 5 / 1)$

Sand, fine, silty, shelly including Oliva and Mulinia; interbedded with

3 - to 6-in.-thick layers of silty clay beds; olive gray $(5 Y 4 / 1)$; grades downward to medium to coarse sand in basal $2 \mathrm{ft}$.

UNCONFORMITY

\section{Goose Creek Limestone}

Sand, medium, very calcareous, phosphatic, partially calcite-indurated, much denser than above, yellowish-gray (5Y 8/1)

Sand, medium, very calcareous and phosphatic, medium-olive-gray (5Y 5/1); calcite-cemented lumps abundant; contains a diverse molluscan fauna including Amusium mortoni, Pecten eboreus, and high-spired turritellid snails.

Sand, medium to coarse, calcareous, medium-olive-gray ( $5 Y 5 / 1)$; contains abundant rounded black $(N 1)$ phosphate pebbles up to $2 \mathrm{~cm}$ in diameter and rounded indurated lumps of Ashley lithology up to $5 \mathrm{~cm}$ in diameter..... 
Ashley Formation, Runnymede Marl Member

Calcarenite, fine, sparsely phosphatic and quartzose, moderate-olive-

brown (5Y 4/4); contains abundant foraminifera tests 78-96

Base of Wando Formation, upper member:

Base of Goose Creek Limestone:

$-35 \mathrm{ft}$ below sea level

Bottomed in Ashley Formation, Runnymede Marl Member 
JA-7: $1.15 \mathrm{mi}$ east of western quadrangle border, $1.2 \mathrm{mi}$ south of northern quadrangle border, in northwest 1/9th of the quadrangle (latitude $32.7329^{\circ}$ N., longitude $79.9804^{\circ}$ W.). Surface elevation $13 \mathrm{ft}$.

LITHOLOGY

DEPTH, IN FEET

Disturbed soil, fine sand containing scattered limestone gravel.

$0-6$

-UNCONFORMITY

\section{Wando Formation, upper member}

Sand, fine, well-sorted, clean, thixotropic; mica flakes and very fine, dark heavy-mineral grains increasingly abundant downward; pale grayish orange (10YR 8/4) grading downward at $9 \mathrm{ft}$ to dark yellowish brown $(10 Y R 4 / 6)$.

Sand, fine; shell hash and very fine, dark heavy-mineral grains abundant; moderate olive gray $(5 Y 4 / 2)$ in top 3 in. grading rapidly downward to moderate greenish gray $(5 G Y 5 / 1)$ $14-18$

Silt, clayey, sandy (very fine), sticky, dark-greenish-gray (5G 4/1) $18-30$

Sand, fine, silty, dark-greenish-gray (5GY 6/1). $30-37$

Sand, medium to coarse, clayey, dark-greenish-gray (5GY 6/1); contains lumps of Goose Creek lithology $37-38$

UNCONFORMITY

\section{Goose Creek Limestone}

Sand, medium, very calcareous and phosphatic; contains abundant calcite-cemented lumps and rare fragments of Pecten eboreus; black $(N 1)$ subrounded to rounded phosphate lumps up to $4 \mathrm{~cm}$ in basal $1 \mathrm{ft}$; light olive gray (5Y 6/1) grading downward around $41 \mathrm{ft}$ to medium olive gray $(5 Y 5 / 1)$

\section{UNCONFORMITY}

\section{Ashley Formation, Runnymede Marl Member}

Calcarenite, sparsely quartzose and phosphatic, moderate-olive-brown (5Y 4/4); mostly composed of foraminifera tests. 49-61

Base of Wando Formation, upper member: Base of Goose Creek Limestone:

\section{Bottomed in Ashley Formation, Runnymede Marl Member}


JA-8: $2.2 \mathrm{mi}$ west of eastern quadrangle border, $1.55 \mathrm{mi}$ south of northern quadrangle border, in northeast 1/9th of the quadrangle (latitude $32.7277^{\circ}$ N., longitude $79.9125^{\circ}$ W.). Surface elevation $11 \mathrm{ft}$.

LITHOLOGY

DEPTH, IN FEET

Fill, very shelly fine sand.

$0-1$

-UNCONFORMITY

\section{Wando Formation, upper member}

Sand, fine, well-sorted, clean; dusky brown (5YR 2/2) grading

downward to yellowish brown (10YR 5/4); grades rapidly downward to $1-4$

Sand, fine to medium, clayey, silty, stiff, micaceous; moderate olive gray $(5 Y 4 / 2)$ and mottled dark yellowish orange (10YR 6/6)

Sand, fine, well-sorted, silty, micaceous, light-olive-brown (5Y 5/6);

very fine, dark heavy-mineral grains abundant

Sand, fine, well-sorted, phosphatic, shelly; 3-in.-thick clayey silt lens at

$19 \mathrm{ft}$; grayish olive $(10 Y 4 / 2)$ grading downward to moderate gray

$(5 G Y 5 / 1)$

Silt, clayey, dense, sticky, moderate-greenish-gray (5GY 5/1)

Sand, fine, well-sorted, phosphatic, shelly, moderate-greenish-gray

$(5 G Y 5 / 1)$

Sand, medium to coarse, clayey, silty, moderate-greenish-gray

$(5 G Y 5 / 1)$

Sand, fine to coarse, phosphatic, soft, moderate-greenish-gray

$(5 G Y 5 / 1)$ $46-51$

\section{UNCONFORMITY}

\section{Goose Creek Limestone}

Sand, medium, very calcareous and phosphatic, moderate-greenishgray (5GY 5/1); calcite-cemented lumps abundant; crunchy drilling

Sand, medium to coarse, subrounded to rounded, very calcareous and phosphatic, moderate-greenish-gray ( $5 G Y 5 / 1)$; phosphate sand concentrated in basal $5 \mathrm{ft}$

-UNCONFORMITY-

\section{Marks Head Formation}

Sand, dominantly fine but with medium to coarse fraction, well-sorted, clayey, silty, olive-brown (5Y3/6); abundant oyster fragments in basal $0.5 \mathrm{ft}$; possibly stopped just above basal contact

Base of Wando Formation, upper member:

Base of Goose Creek Limestone:

$-40 \mathrm{ft}$ below sea level

Bottomed in Marks Head Formation 


\section{Kiawah Island Quadrangle}

KI-1: 1.2 mi east of western quadrangle border, $1.45 \mathrm{mi}$ south of northern quadrangle border, in northwest 1/9th of the quadrangle (latitude $32.6048^{\circ} \mathrm{N}$., longitude $80.1048^{\circ} \mathrm{W}$.). Surface elevation $6 \mathrm{ft}$.

\section{LITHOLOGY}

DEPTH, IN FEET

\section{Holocene beach sand}

Sand, fine, well-sorted, clean, slightly micaceous, thixotropic; fine, dark heavy-mineral grains abundant; yellowish gray $(5 Y 7 / 2)$ grading downward through dusky brown $(5 Y R 2 / 2)(0.5-1.0 \mathrm{ft})$ and very light olive gray $(5 Y 6 / 2)(1-4 \mathrm{ft})$ to dark grayish green $(5 G 4 / 2)$

Sand, fine, well-sorted, clean, slightly micaceous, thixotropic, darkgrayish-green $(5 G 4 / 2)$; fine, dark heavy-mineral grains abundant; shelly (mostly Mulinia)

Silt, clayey, sandy (very fine), greasy, sticky, micaceous, mediumgreenish-gray $(5 G Y 5 / 1)$

Sand, fine to medium, silty, shelly (mostly Mulinia but also including Dinocardium, Busycon, Anadara ovalis, Oliva, and Polinices), soft, medium-greenish-gray $(5 G 5 / 1)$

Shell hash, sandy, sand fraction medium to coarse and rounded, soft, medium-greenish-gray (5G 5/1); fulsome odor present; basal $1 \mathrm{ft}$ has rounded quartz granules. $40-46$

-UNCONFORMITY

\section{Wando Formation, middle member}

Silt, denser than above, medium-greenish-gray ( $5 G 5 / 1)$; basal $1 \mathrm{ft}$ has fine to medium rounded quartz sand fraction; rounded phosphate pebbles and rounded lumps of Ashley lithology up to $8 \mathrm{~cm}$ in diameter.

\section{UNCONFORMITY}

\section{Ashley Formation, Runnymede Marl Member}

Calcarenite, fine; light olive brown (5Y 5/4) grading downward through olive brown (5Y3/4) back to light olive brown (5Y 5/4)

Calcarenite, fine; interbedded with calcite-cemented layers; light olive brown (5Y 5/4); tough drilling.

Calcarenite, fine; mostly composed of foraminifera tests; light olive brown $(5 Y 5 / 4)$ grading downward at $96 \mathrm{ft}$ to moderate olive brown $(5 Y 4 / 4)$.

Base of Holocene beach sand:

Base of Wando Formation, middle member:

\section{Bottomed in Ashley Formation, Runnymede Marl Member}


KI-2: $\quad 3.5 \mathrm{mi}$ west of eastern quadrangle border, $1.05 \mathrm{mi}$ south of northern quadrangle border, in north-central $1 / 9$ th of the quadrangle (latitude $32.6089^{\circ} \mathrm{N}$., longitude $80.0600^{\circ} \mathrm{W}$.). Surface elevation $10 \mathrm{ft}$.

\section{LITHOLOGY}

DEPTH, IN FEET

\section{Holocene beach sand}

Sand, fine, well-sorted, finely micaceous; very fine, dark heavy-mineral grains abundant; contains fragments of Mulinia shells; yellowish gray $(5 Y 7 / 2)$ grading downward at $6 \mathrm{ft}$ to medium greenish gray $(5 G Y 5 / 1)$.

Sand, fine, well-sorted, finely micaceous, dark-greenish-gray (5GY 4/1); very fine, dark heavy-mineral grains abundant; Mulinia shells common

Silt, clayey, greasy, sticky, dark-grayish-green (5GY 4/1); fulsome odor present; basal $1 \mathrm{ft}$ sandy

Sand, fine to medium, silty, light-olive (10Y 5/2); contains abundant shell hash including fragments of Mulinia and Busycon; grades rapidly downward to

Sand, medium to coarse, light-olive-gray ( $5 Y$ 6/1); contains abundant shell hash, rounded coarse phosphate sand, and rounded very coarse quartz grains

UNCONFORMITY

\section{Ashley Formation, Runnymede Marl Member}

Calcarenite, fine, moderate-olive-brown ( $5 Y 4 / 4)$; mostly composed of foraminifera tests

Calcarenite, fine, much more clayey than above, moderate-olive-brown (5Y 4/4); mostly composed of foraminifera tests

Base of Holocene beach sand:

$-54 \mathrm{ft}$ below sea level

Bottomed in Ashley Formation, Runnymede Marl Member 
KI-3: $1.2 \mathrm{mi}$ west of eastern quadrangle border, $0.85 \mathrm{mi}$ south of northern quadrangle border, in northeast 1/9th of the quadrangle (latitude $32.6132^{\circ} \mathrm{N}$., longitude $80.0191^{\circ} \mathrm{W}$.). Surface elevation $7 \mathrm{ft}$.

LITHOLOGY

DEPTH, IN FEET

Road fill, disturbed sand. $0-1$

-UNCONFORMITY

\section{Holocene beach sand}

Sand, fine, clean; very fine, dark heavy-mineral grains abundant;

Mulinia shell fragments present; moderate olive gray $(5 Y 4 / 2)$ grading

downward at $6 \mathrm{ft}$ to medium gray $(5 G Y 5 / 1)$.

Silt, sandy (very fine), medium-greenish-gray ( $5 G Y 5 / 1)$; fulsome odor

present

Sand, fine, silty, soft, olive-gray ( $5 Y 3 / 2)$

Gravel, composed of lumpy, subangular, pitted phosphate pebbles up to

$8 \mathrm{~cm}$ in diameter; black $(N 1)$

\section{UNCONFORMITY}

\section{Ashley Formation, Runnymede Marl Member}

Calcarenite, fine; mostly composed of foraminifera tests; burrows in upper $1 \mathrm{ft}$ filled with black $(N 1)$ phosphate pebbles; moderate olive brown $(5 Y 4 / 4)$ grading downward at about $48 \mathrm{ft}$ to light olive brown $(5 Y 5 / 4)$

Calcarenite, fine, increasingly quartzose and phosphatic downward,

light-olive-brown ( $5 Y 5 / 4)$; mostly composed of foraminifera tests

Sand, fine to medium, phosphatic, calcareous, moderate-olive-gray (5Y 4/2); phosphate grains rounded

\section{UNCONFORMITY}

\section{Parkers Ferry Formation}

Calcisiltite, clayey, sticky, finely micaceous; light olive gray (5Y 6/2) grading downward to light grayish olive (10Y 5/2); difficult to remove from auger flights $88-106$

Base of Holocene beach sand:

Base of Ashley Formation, Runnymede Marl Member:

$-37 \mathrm{ft}$ below sea level $-81 \mathrm{ft}$ below sea level

\section{Bottomed in Parkers Ferry Formation}




\section{Legareville Quadrangle}

LE-1: $3.4 \mathrm{mi}$ west of eastern quadrangle border, $1.7 \mathrm{mi}$ south of northern quadrangle border, in northcentral 1/9th of the quadrangle (latitude $32.7261^{\circ} \mathrm{N}$., longitude $80.0584^{\circ} \mathrm{W}$.). Surface elevation $17 \mathrm{ft}$.

\section{LITHOLOGY}

DEPTH, IN FEET

\section{Wando Formation, upper member}

Sand, fine, well-sorted, dusky-brown (5YR 2/2); contains very fine to

fine, dark heavy-mineral grains

Sand, fine, thixotropic; contains scattered coarse and very fine, dark heavy-mineral grains; basal $2 \mathrm{ft}$ shelly; dark yellowish orange

(10YR 6/6) grading downward through yellowish gray $(5 Y 7 / 2)(2-3 \mathrm{ft})$

then through grayish orange (10YR 7/4) (3-6 ft) and through dusky

yellow $(5 Y 6 / 4)(6-10 \mathrm{ft})$ to medium dark gray $(N 4)$

Silt, clayey, sandy (very fine), micaceous; contains scattered

carbonaceous streaks; medium dark gray $(N 4)$ grading downward by

$14 \mathrm{ft}$ to medium gray $(N 5)$

Sand, very fine to medium, poorly sorted, medium-gray ( $N 5)$; shelly, including snail, oyster, and Mulinia; contains rounded phosphate pebbles up to $5 \mathrm{~cm}$ in diameter.

-UNCONFORMITY

\section{Parkers Ferry Formation}

Calcarenite, fine, silty, dense, light-olive (10Y 5/2)

Calcarenite, very fine to fine, very finely micaceous, light-olive

(10Y 5/2); contains scattered large foraminifera tests and echinoid

spines

Base of Wando Formation, upper member:

$-18 \mathrm{ft}$ below sea level

\section{Bottomed in Parkers Ferry Formation}


LE-2: $1.3 \mathrm{mi}$ east of western quadrangle border, $4.45 \mathrm{mi}$ south of northern quadrangle border, in west-central $1 / 9$ th of the quadrangle (latitude $32.6861^{\circ} \mathrm{N}$., longitude $80.1023^{\circ} \mathrm{W}$.). Surface elevation $12 \mathrm{ft}$.

LITHOLOGY

DEPTH, IN FEET

\section{Wando Formation, upper member}

Sand, fine, well-sorted, silty; grayish brown $(5 Y R 3 / 2)$ grading

downward to dark yellowish orange (10YR 6/6).

Sand, very fine to fine; stiff and clayey between 2 and $4 \mathrm{ft}$, micaceous sand below that; dark yellowish orange (10YR 6/6) grading downward through grayish yellow $(5 Y 8 / 1)$ and mottled dark yellowish orange $(10 Y R$ 6/6) $(2-5 \mathrm{ft})$ to light gray $(N 7)$ and mottled dark yellowish orange (10YR 6/6)

Sand, very fine to fine, dark-gray $(N 3)$; very fine, dark heavy-mineral grains present; shelly (mostly Mulinia)

Silt, clayey, greasy, sticky; thin layers of dusky brown (5YR 2/2) peat at

$13 \mathrm{ft}$ and $18 \mathrm{ft}$; dark gray $(N 3)$; grades downward to

Silt, clayey, greasy, sticky, shelly, greenish-gray ( $5 G 6 / 1)$

Sand, fine to medium, silty, greenish-gray ( $5 G 6 / 1)$; very shelly,

including Mulinia, Busycon, and Anadara ovalis. $32-36$

-UNCONFORMITY

\section{Wando Formation, middle member}

Silt, sandy (very fine), clayey, dark-gray (N3); contains occasional thin laminae of very fine sand; basal $1 \mathrm{ft}$ micaceous and contains rounded phosphate pebbles up to $4 \mathrm{~cm}$ in diameter..

-UNCONFORMITY

\section{Parkers Ferry Formation}

Calcarenite, very fine, light-olive-brown ( $5 Y$ 5/6); contains sparse small

foraminifera tests

Calcisiltite, sandy (very fine to fine), light-olive (10Y 5/2); contains sparse small foraminifera tests. $76-101$

Base of Wando Formation, upper member:

$-24 \mathrm{ft}$ below sea level

Base of Wando Formation, middle member:

$-\mathbf{5 7} \mathrm{ft}$ below sea level

\section{Bottomed in Parkers Ferry Formation}


LE-3: $1.2 \mathrm{mi}$ east of western quadrangle border, $1.3 \mathrm{mi}$ south of northern quadrangle border, in northwest 1/9th of the quadrangle (latitude $32.7311^{\circ}$ N., longitude $80.1048^{\circ} \mathrm{W}$.). Surface elevation $20 \mathrm{ft}$.

\section{LITHOLOGY}

DEPTH, IN FEET

\section{Wando Formation, upper member}

Sand, fine, well-sorted; dusky brown (5YR 2/2) grading downward to grayish orange $(5 Y R 7 / 4)$

Sand, fine, well-sorted, finely micaceous, thixotropic; grayish orange (5YR 7/4) and mottled dark yellowish orange (10YR 6/6) grading downward to light grayish brown $(5 Y R 4 / 2)$.

Sand, fine, well-sorted, more coarsely micaceous than layer above; fine to very fine, dark heavy-mineral grains present; medium olive gray $(5 Y 5 / 1)$ grading downward by $19 \mathrm{ft}$ to medium light gray $(N 6)$

Sand, fine, well-sorted, interlayered with silt, clayey, sandy (very fine to fine); medium light gray ( $N 6)$

Sand, mostly fine but some very fine to medium, poorly sorted, medium-light-gray $(N 6)$; contains subangular to subrounded lumps of phosphate up to $2 \mathrm{~cm}$ in diameter.

UNCONFORMITY

\section{Ashley Formation, Givhans Ferry Member}

Calcarenite, fine to medium, quartzose and phosphatic; some foraminifera tests visible; ranges from light olive gray $(5 Y 5 / 2)$ to medium olive gray $(5 Y 5 / 1)$.....

Base of Wando Formation, upper member:

$-19 \mathrm{ft}$ below sea level

Bottomed in Ashley Formation, Givhans Ferry Member 
LE-4: $3.1 \mathrm{mi}$ east of western quadrangle border, $3.9 \mathrm{mi}$ south of northern quadrangle border, in central 1/9th of the quadrangle (latitude $32.6936^{\circ}$ N., longitude $80.0722^{\circ} \mathrm{W}$.). Surface elevation $21 \mathrm{ft}$.

\section{LITHOLOGY}

DEPTH, IN FEET

\section{Wando Formation, upper member}

Sand, fine, well-sorted; dusky brown (5YR 2/2) grading downward to brownish orange (5YR 6/6); grades downward to

Sand, fine, well-sorted, slightly micaceous, thixotropic; very fine, dark heavy-mineral grains abundant; pale yellowish gray $(5 Y 8 / 1)$ grading downward through yellowish gray $(5 Y 7 / 2)(14-18 \mathrm{ft})$ back to pale yellowish gray $(5 Y 8 / 1)$; grades rapidly downward to.....

Sand, fine to medium, dark-gray $(N 3)$; shelly, including barnacles,

Mulinia, Noetia, and others

Silt, clayey, sandy (very fine), greasy, dark-brownish-gray (5YR 3/1); grades downward to.....

Peat, reddish-brown (5R 2/2)

\section{UNCONFORMITY}

\section{Wando Formation, middle member}

Clay, dense, carbonaceous, micaceous, dark-greenish-gray (5GY 4/1);

thin sandy (very fine) lenses abundant

No recovery, smooth drilling, presumably as above. $36-40$

Gravel, crunchy and slow drilling, recovered scattered hunks of rough phosphate rock up to $3 \mathrm{~cm}$ in diameter; presumably basal hard bed $40-42$

-UNCONFORMITY

\section{Parkers Ferry Formation}

Calcisiltite, dense, finely micaceous, light-olive (10Y 5/2); contains echinoid spines and rare foraminifera tests

Base of Wando Formation, upper member:

Base of Wando Formation, middle member:

$-9 \mathrm{ft}$ below sea level $-21 \mathrm{ft}$ below sea level

Bottomed in Parkers Ferry Formation 
LE-5: $1.1 \mathrm{mi}$ west of eastern quadrangle border, $1.7 \mathrm{mi}$ south of northern quadrangle border, in northeast 1/9th of the quadrangle (latitude $32.7259^{\circ} \mathrm{N}$., longitude $80.0191^{\circ} \mathrm{W}$.). Surface elevation $12 \mathrm{ft}$.

\section{LITHOLOGY}

DEPTH, IN FEET

\section{Wando Formation, upper member}

Sand, fine, well-sorted, dusky-brown (5YR 2/2) and dark-yellowishorange $(10 Y R 6 / 6)$

Sand, very fine to fine, silty, clayey, micaceous, dark-yellowish-brown $(10 Y R 4 / 6)$

Sand, fine, well-sorted; fine, dark heavy-mineral grains abundant; dark yellowish brown $(10 Y R$ 4/6) grading downward to yellowish gray $(5 Y 8 / 1)$

Sand, fine, well-sorted, silty, dark-olive-gray (5Y 3/1)

Sand, fine, well-sorted, silty, sparsely micaceous, thixotropic, darkolive-gray (5Y3/1); shell fragments present

Sand, fine to medium, silty, sparsely micaceous, dark-olive-gray (5Y3/1); shelly, including Anadara transversa and Mulinia among others

Sand, medium to coarse, shelly, dark-olive-gray (5Y3/1); contains abundant phosphate pebbles $1-3 \mathrm{~cm}$ in diameter

\section{Parkers Ferry Formation}

Calcarenite, very fine to fine, light-olive (10Y 5/2). $35-41$

Base of Wando Formation, upper member:

\section{Bottomed in Parkers Ferry Formation}


LE-6: $1.5 \mathrm{mi}$ west of eastern quadrangle border, $4.1 \mathrm{mi}$ south of northern quadrangle border, in east-central 1/9th of the quadrangle (latitude $32.6907^{\circ}$ N., longitude $80.0254^{\circ}$ W.). Surface elevation $14 \mathrm{ft}$.

\section{LITHOLOGY}

DEPTH, IN FEET

\section{Wando Formation, upper member}

Sand, fine, well-sorted, thixotropic; dusky brown $(5 Y R 2 / 2)$ with streaks of grayish orange (10YR 7/4)

Sand, fine, well-sorted, shelly, thixotropic, dark-olive-gray (5Y3/1).

Sand, very fine to fine, silty, dark-olive-gray ( $5 Y 3 / 1)$; very fine to fine, dark heavy-mineral grains abundant; more shelly than above, including Mulinia and Oliva among others; grades downward to

Sand, very fine to fine, very silty, micaceous, clayey toward base, darkolive-gray $(5 Y 3 / 1)$

Peat, dark-reddish-brown (10R 2/2)

Silt, clayey, dense, medium-greenish-gray ( $5 G Y 5 / 1)$; contains abundant roots

\section{UNCONFORMITY}

\section{Wando Formation, middle member}

Shell hash, light-olive-gray ( $5 Y$ 5/2); mostly composed of Mulinia shell fragments $29-44$

Silt, dense, clayey, dark-gray $(N 3)$

\section{UNCONFORMITY}

\section{Wando Formation, lower member}

Sand, fine, well-sorted, light-gray $(N 7)$; contains abundant very fine to

fine, dark heavy-mineral grains

Sand, fine to coarse, light-gray $(N 7)$; contains abundant rounded phosphate pebbles up to $2 \mathrm{~cm}$ in diameter

\section{Parkers Ferry Formation}

Calcisiltite, dense, sticky, light-olive (10Y 5/2); contains echinoid spines

Base of Wando Formation, upper member:

Base of Wando Formation, middle member:

Base of Wando Formation, lower member:

$-15 \mathrm{ft}$ below sea level

$-33 \mathrm{ft}$ below sea level

$-43 \mathrm{ft}$ below sea level

\section{Bottomed in Parkers Ferry Formation}


LE-7: 3.5 mi east of western quadrangle border, $1.75 \mathrm{mi}$ north of southern quadrangle border, in south-central $1 / 9$ th of the quadrangle (latitude $32.6504^{\circ} \mathrm{N}$., longitude $80.0646^{\circ} \mathrm{W}$.). Surface elevation $12 \mathrm{ft}$.

LITHOLOGY

DEPTH, IN FEET

\section{Wando Formation, upper member}

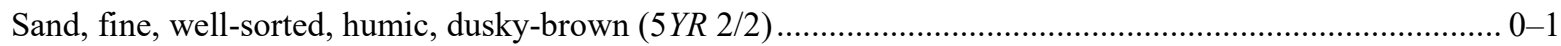

Sand, fine, well-sorted, thixotropic; very fine, dark heavy-mineral grains abundant; yellowish gray $(5 Y 7 / 2)$ grading downward to dark yellowish orange $(10 Y R 6 / 6)$.....

Sand, fine, well-sorted, shelly (mostly Mulinia), thixotropic; medium olive gray $(5 Y 5 / 1)$ grading downward by $11 \mathrm{ft}$ to medium dark gray $(N 4)$

Sand, very fine to fine, silty, thixotropic; very fine, dark heavy-mineral grains abundant; shelly, mostly Mulinia but also includes oyster and Anadara brasiliana; medium dark gray $(N 4)$ grading downward by $19 \mathrm{ft}$ to greenish gray $(5 G 6 / 1)$; several thin medium-gray $(N 5)$ clay lenses present between 20 and $21 \mathrm{ft} .$.

Clay, silty, medium-gray ( $N 5)$.

Sand, fine, silty, greenish-gray ( $5 G 6 / 1)$; very fine, dark heavy-mineral grains abundant; contains abundant shell hash

Shell hash, sandy (fine), light-yellowish-gray (5Y 8/1).

\section{UNCONFORMITY}

\section{Wando Formation, middle member}

Silt, clayey, medium-light-gray $(N 6)$; grades downward to

Sand, fine, well-sorted, sparsely shelly, greenish-gray ( $5 G 6 / 1)$; very

fine, dark heavy-mineral grains abundant; a few clayey lenses present $31-36$

Sand, fine to medium grading downward to medium to coarse, coarser

fraction subrounded to rounded, clean, brownish-gray $(5 Y R 4 / 1)$

-UNCONFORMITY

\section{Wando Formation, lower member}

Silt, clayey, dark-gray $(N 3)$ $50-53$

Shell hash, light-yellowish-gray $(5 Y 8 / 1)$ $53-56$

Sand, fine to coarse, poorly sorted, rounded, light-gray $(N 7)$; contains abundant shell fragments $56-61$

-UNCONFORMITY

\section{Parkers Ferry Formation}

Calcisiltite, stiff, light-olive (10Y 5/2); contains scattered foraminifera tests. $61-81$

Base of Wando Formation, upper member:

Base of Wando Formation, middle member:

Base of Wando Formation, lower member:

Bottomed in Parkers Ferry Formation
$-17 \mathrm{ft}$ below sea level $-38 \mathrm{ft}$ below sea level $-49 \mathrm{ft}$ below sea level 
LE-8: $1.15 \mathrm{mi}$ east of western quadrangle border, $1.35 \mathrm{mi}$ north of southern quadrangle border, in southwest 1/9th of the quadrangle (latitude $32.6445^{\circ}$ N., longitude $80.1057^{\circ} \mathrm{W}$.). Surface elevation $12 \mathrm{ft}$.

LITHOLOGY

DEPTH, IN FEET

\section{Wando Formation, upper member}

Sand, fine, well-sorted, humic, dusky-brown (5YR 2/2). $0-1$

Sand, fine, well-sorted, yellowish-gray (5Y7/2); very fine, dark heavy-

mineral grains abundant.

Sand, fine, well-sorted, finely micaceous, thixotropic; very fine, dark

heavy-mineral grains abundant; shelly below $15 \mathrm{ft}$; yellowish gray

$(5 Y 7 / 2)$ grading downward by $9 \mathrm{ft}$ to medium olive gray $(5 Y 5 / 1)$

Shell hash, mostly Mulinia but with a few Oliva; medium olive gray

$(5 Y 5 / 1)$

Peat, dark-reddish-brown $(5 R 2 / 2)$.

Silt, clayey, grayish-brown ( $5 Y R 3 / 2)$; contains root fragments

$22-23$

UNCONFORMITY-

Wando Formation, middle member

Silt, clayey, sandy (very fine), micaceous, greenish-gray (5G 6/1);

contains a few chalky oyster shells.

Sand, fine, very silty, greenish-gray ( $5 G 6 / 1)$; contains a few Mulinia and Anadara ovalis shells

Sand, fine to coarse, poorly sorted, greenish-gray $(5 G 6 / 1)$; contains many oyster fragments and rounded phosphate pebbles up to $3 \mathrm{~cm}$ in diameter; bone fragment present

-UNCONFORMITY

\section{Marks Head Formation}

Sand, fine to medium, moderate-olive-brown ( $5 Y 4 / 4)$; contains scattered phosphate pebbles.

\section{UNCONFORMITY}

\section{Ashley Formation, Givhans Ferry Member}

Calcarenite, quartzose and phosphatic; large foraminifera tests present and a large thin-shelled mollusk shell fragment; grayish yellow (5Y7/4)

grading downward to grayish olive $(5 Y 4 / 2)$. $50-61$

Calcarenite, quartzose and phosphatic, grayish-olive (5Y 4/2); large

foraminifera tests present; strong hydrogen sulfide odor present ... $61-86$

Base of Wando Formation, upper member:

Base of Wando Formation, middle member:

Base of Marks Head Formation:

$-11 \mathrm{ft}$ below sea level

$-37 \mathrm{ft}$ below sea level $-38 \mathrm{ft}$ below sea level

\section{Bottomed in Ashley Formation, Givhans Ferry Member}


LE-9: $1.3 \mathrm{mi}$ west of eastern quadrangle border, $2.15 \mathrm{mi}$ north of southern quadrangle border, in southeast 1/9th of the quadrangle (latitude $32.6566^{\circ} \mathrm{N}$., longitude $80.0219^{\circ} \mathrm{W}$.). Surface elevation $7 \mathrm{ft}$.

LITHOLOGY

DEPTH, IN FEET

\section{Wando Formation, upper member}

Sand, fine, well-sorted; very fine, dark heavy-mineral grains abundant; dusky brown $(5 Y R 2 / 2)$ grading downward by $0.5 \mathrm{ft}$ to grayish orange

(10YR 7/4), streaked yellowish gray (5Y7/2) in basal $2 \mathrm{ft}$ $0-6$

Sand, fine, well-sorted, slightly silty, grayish-orange (10YR 7/4); very

fine, dark heavy-mineral grains abundant; grades rapidly downward to

Sand, fine, well-sorted, slightly silty, medium-bluish-gray ( $5 B$ 5/1);

very fine, dark heavy-mineral grains abundant; increasingly shelly

downward (mostly oyster and Mulinia).

UNCONFORMITY

\section{Wando Formation, middle member}

Silt, clayey, greenish-gray $(5 G 6 / 1)$...

Silt, clayey, sandy (very fine), sparsely shelly, greenish-gray (5G 6/1);

grades rapidly downward to.

Sand, fine, very shelly, greenish-gray ( $5 G 6 / 1)$; very fine, dark heavy-

mineral grains abundant.

-UNCONFORMITY-

Wando Formation, lower member

Silt, clayey, sandy (very fine), greenish-gray ( $5 G 6 / 1)$

Sand, fine to medium grading downward by base to medium to coarse, silty, greenish-gray ( $5 G 6 / 1)$; abundant phosphate sand; shell and shell

fragments abundant; pebbles present near base.

-UNCONFORMITY

\section{Daniel Island beds}

Silt, clayey, sandy (very fine), finely micaceous, dark-gray ( $N 3)$;

densely packed phosphate pebbles up to $1 \mathrm{~cm}$ in diameter at base. $61-68$

-UNCONFORMITY

\section{Parkers Ferry Formation}

Calcisiltite, light-olive (10Y 5/2) $68-76$

Base of Wando Formation, upper member:

Base of Wando Formation, middle member:

Base of Wando Formation, lower member:

Base of Daniel Island beds:

$-13 \mathrm{ft}$ below sea level

$-30 \mathrm{ft}$ below sea level

$-54 \mathrm{ft}$ below sea level

$-61 \mathrm{ft}$ below sea level

\section{Bottomed in Parkers Ferry Formation}




\section{Maple Cane Swamp Quadrangle}

MS-1: $1.4 \mathrm{mi}$ west of eastern quadrangle border, $2.05 \mathrm{mi}$ north of southern quadrangle border, in southeast 1/9th of the quadrangle (latitude $33.0299^{\circ}$ N., longitude $80.3982^{\circ}$ W.). Surface elevation $34 \mathrm{ft}$.

\section{LITHOLOGY}

DEPTH, IN FEET

\section{Edisto River alluvium}

Sand, medium to coarse, subangular, clean; sparse very coarse grains present; grayish brown (5YR 3/2) grading downward to light yellowish brown $(10 Y R 6 / 4)$

Sand, mostly medium, better sorted than above, subangular to angular; upper $1 \mathrm{ft}$ orange (10YR 6/8) grading rapidly downward to very pale orange $(10 Y R 8 / 2)$.

\section{-UNCONFORMITY}

\section{Ashley Formation, Givhans Ferry Member}

Calcarenite, fine, well-sorted but with a few scattered medium to coarse grains, silty, quartzose and phosphatic, moderate-olive-brown (5Y 4/4); basal 2 in. very phosphatic and quartzose; rounded phosphate pebbles up to $2 \mathrm{~cm}$ in diameter on basal contact. $10-23$

\section{UNCONFORMITY}

\section{Ashley Formation, Runnymede Marl Member}

Calcarenite, fine, well-sorted, no quartz or phosphate sand, light-olivebrown $(5 Y 5 / 4)$.

Calcarenite, fine, well-sorted, no quartz or phosphate sand, indurated, light-olive-brown ( $5 Y 5 / 4)$; tough drilling

Calcarenite, fine, silty, increasingly clayey toward base, light-olivebrown (5Y 5/4); broken shell fragments abundant on basal contact

\section{Parkers Ferry Formation}

Calcarenite, very fine, clayey, stiff, sticky, olive (10Y 4/4). $71-85$

Base of Edisto River alluvium:

Base of Ashley Formation, Givhans Ferry Member: Base of Ashley Formation, Runnymede Marl Member:

\section{Bottomed in Parkers Ferry Formation}

$+24 \mathbf{f t}$ above sea level $+11 \mathrm{ft}$ above sea level $-37 \mathrm{ft}$ below sea level 
MS-2: $2.9 \mathrm{mi}$ east of western quadrangle border, $3.75 \mathrm{mi}$ north of southern quadrangle border, in central 1/9th of the quadrangle (latitude $33.0549^{\circ}$ N., longitude $80.4501^{\circ}$ W.). Surface elevation $42 \mathrm{ft}$.

\section{LITHOLOGY}

DEPTH, IN FEET

\section{Edisto River alluvium}

Sand, medium to very coarse, poorly sorted, humic, grayish-red $(5 R 4 / 2)$

Sand, medium to very coarse, poorly sorted, clean; very light brownish gray $(5 Y R 7 / 1)$ grading downward to pale grayish orange $(10 Y R 8 / 4)$

Sand, medium to coarse, clean, pale-orange (10YR 7/2); contains

feldspar and garnet grains; grades downward to.

Sand, medium to very coarse, poorly sorted, granular, pale-orange

(10YR 7/2)

\section{-UNCONFORMITY}

\section{Ashley Formation, Givhans Ferry Member}

Calcarenite, fine, quartzose and phosphatic; foraminifera tests abundant; brown $(5 Y 3 / 4)$ in top $0.5 \mathrm{ft}$ grading downward to light olive brown ( $5 Y 5 / 4)$; grades downward to.

Calcarenite, moderate-olive (10Y 4/4); quartz and phosphate sand abundant; large foraminifera tests abundant; phosphate pebbles on basal contact

\section{UNCONFORMITY}

\section{Ashley Formation, Runnymede Marl Member}

Calcarenite, fine, no quartz or phosphate; composed mostly of foraminifera tests; moderate yellowish olive (10Y 6/4) grading downward by $36 \mathrm{ft}$ to light olive brown (5Y 5/4); NP 24/25 nannofossil assemblage at $45 \mathrm{ft}$.....

Base of Edisto River alluvium:

Base of Ashley Formation, Givhans Ferry Member:

$+30 \mathrm{ft}$ above sea level +9 ft above sea level

\section{Bottomed in Ashley Formation, Runnymede Marl Member}


MS-3: $1.0 \mathrm{mi}$ east of western quadrangle border, $1.45 \mathrm{mi}$ north of southern quadrangle border, in southwest 1/9th of the quadrangle (latitude $33.0211^{\circ} \mathrm{N}$., longitude $80.4827^{\circ} \mathrm{W}$.). Surface elevation $57 \mathrm{ft}$.

\section{LITHOLOGY}

DEPTH, IN FEET

\section{Ladson Formation}

Sand, medium to coarse, subangular to subrounded, clayey, humic; dusky yellowish brown (10YR 2/2) grading downward to moderate grayish orange $(10 Y R 6 / 4)$ $0-1$

Sand, fine to very coarse, very poorly sorted, clean; dark pinkish gray (5YR 7/1) grading downward to orange (10YR 5/6)

Sand, fine to very coarse, very poorly sorted, silty; dark pinkish gray $(5 Y R 7 / 1)$ grading downward by $15 \mathrm{ft}$ to dark brownish gray $(5 Y R 3 / 1)$

\section{UNCONFORMITY}

\section{Parachucla Shale}

Clay, becoming increasingly sandy (very fine) downward, cheesy texture, slightly micaceous; dark olive gray $(5 Y 2 / 2)$ grading downward through dark olive brown (5Y 2/4) (20-21 ft) back to dark olive gray $(5 Y 2 / 2)$

\section{UNCONFORMITY}

\section{Ashley Formation, Runnymede Marl Member}

Calcarenite, fine, slightly quartzose and phosphatic, light-olive-brown

(5Y 5/4); mostly composed of foraminifera tests; glauconitic toward base; grades downward to...

Calcarenite, fine, quartzose, phosphatic, glauconitic, olive-brown (5Y 3/4); abundant foraminifera tests; fine to medium quartz abundant in basal $1 \mathrm{ft}$

-UNCONFORMITY

\section{Harleyville Formation, Osborn Member}

Calcarenite, fine, soft, light-grayish-olive (10Y 5/2); composed of

Base of Ladson Formation:

Base of Parachucla Shale:

Base of Ashley Formation, Runnymede Marl Member:

\section{Bottomed in Harleyville Formation, Osborn Member}


MS-4: $1.4 \mathrm{mi}$ west of eastern quadrangle border, $2.65 \mathrm{mi}$ south of northern quadrangle border, in northeast 1/9th of the quadrangle (latitude $33.0861^{\circ}$ N., longitude $80.3977^{\circ}$ W.). Surface elevation $42 \mathrm{ft}$.

\section{LITHOLOGY}

DEPTH, IN FEET

\section{Four Hole Swamp alluvium}

Sand, dominantly medium to coarse but up to very coarse, sparsely granular, clean; yellowish orange $(10 Y R 7 / 6)$ grading rapidly downward to very dark yellowish brown $(10 Y R 3 / 2)$...

\section{UNCONFORMITY}

\section{Ten Mile Hill Formation (?)}

Sand, fine, well-sorted, clayey, silty, brownish-gray (5YR 4/1) 4-8

Sand, fine, well-sorted, clean, thixotropic, light-olive-gray ( $5 Y 5 / 2)$ $8-9$

\section{UNCONFORMITY}

\section{Ashley Formation, Runnymede Marl Member}

Calcarenite, fine, silty, no quartz or phosphate sand, light-olive-brown

(5Y 5/4); composed of foraminifera tests; NP 24 nannofossil assemblage at $40 \mathrm{ft}$

Base of Four Hole Swamp alluvium: Base of Ten Mile Hill Formation (?):

\section{Bottomed in Ashley Formation, Runnymede Marl Member}


MS-5: $1.0 \mathrm{mi}$ east of western quadrangle border, $1.45 \mathrm{mi}$ north of southern quadrangle border, in northwest 1/9th of the quadrangle (latitude $33.0949^{\circ}$ N., longitude $80.4946^{\circ}$ W.). Surface elevation $87 \mathrm{ft}$.

\section{LITHOLOGY}

DEPTH, IN FEET

\section{Wicomico formation}

Sand, fine, well-sorted, clean, yellowish-orange $(10 Y R$ 7/6) $0-3$

Sand, fine, well-sorted, clean, very-pale-orange (10YR 8/2); very fine to

fine, dark heavy-mineral grains present; grades downward to

Sand, fine grading downward to fine to medium, clean, humic; very

fine to fine, dark heavy-mineral grains present; grayish brown

$(5 Y R 3 / 2)$ grading downward at $14 \mathrm{ft}$ to very pale orange $(10 Y R 8 / 2)$

Sand, medium to coarse, subangular to subrounded, dark-grayishorange (10YR 6/4).

\section{UNCONFORMITY}

\section{Ashley Formation, Givhans Ferry Member}

Sand, fine, dark-olive-brown (5Y 4/2); weathered Ashley

Calcarenite, fine, light-olive-brown (5Y 5/4); mostly composed of

foraminifera tests

Calcarenite, fine, very phosphatic, light-olive-brown (5Y 5/4);

foraminifera tests abundant; rounded phosphate granules and pebbles

up to $1 \mathrm{~cm}$ in diameter also abundant .....

-UNCONFORMITY

\section{Ashley Formation, Runnymede Marl Member}

Calcarenite, fine, soft, slightly phosphatic, no quartz sand, olive (10Y 5/2); contains occasional indurated layers; NP 24 nannofossil assemblage at $76 \mathrm{ft}$

Base of Wicomico formation:

Base of Ashley Formation, Givhans Ferry Member:

$+47 \mathrm{ft}$ above sea level $+36 \mathrm{ft}$ above sea level

\section{Bottomed in Ashley Formation, Runnymede Marl Member}


MS-6: $2.3 \mathrm{mi}$ west of eastern quadrangle border, $0.65 \mathrm{mi}$ south of northern quadrangle border, in northeast $1 / 9$ th of the quadrangle (latitude $33.1156^{\circ}$ N., longitude $80.3977^{\circ}$ W.). Surface elevation $80 \mathrm{ft}$.

\section{LITHOLOGY}

DEPTH, IN FEET

\section{Wicomico formation}

Sand, fine, well-sorted, slightly silty, increasingly clayey downward; dark yellowish brown (10YR 3/2) grading downward through dark yellowish orange $(10 Y R 6 / 6)$ and through moderate yellowish brown $(10 Y R 5 / 4)$ to reddish orange $(10 R 5 / 6)$ and mottled light olive gray $(5 Y 6 / 1)$. $0-6$

Sand, fine grading downward to fine to coarse, poorly sorted, silty, grayish-orange (10YR 7/4).

Sand, fine to coarse, poorly sorted; pinkish gray (5YR 8/1) grading downward to pale grayish orange $(10 Y R$ 8/4).

Sand, very fine to fine, very clayey and silty, sticky, yellowish-gray $(5 Y 7 / 2)$

Clay, silty, greasy, medium-olive-gray (5Y 5/1) $17-17.4$

Sand, fine, well-sorted, clean, pale-olive-gray ( $5 Y 7 / 1)$.

Clay, greasy; interbedded with very fine to fine sand; rounded quartz pebbles up to $3 \mathrm{~cm}$ in diameter on basal contact; medium greenish gray $(5 G Y 5 / 1)$

UNCONFORMITY

\section{Ashley Formation, Givhans Ferry Member}

Sand, fine, well-sorted, olive-brown (5Y 3/4); some foraminifera tests visible

Calcarenite, fine, clayey, very quartzose, finely micaceous, moderateolive-brown (5Y 4/4); foraminifera tests abundant ....

Sand, dominantly fine to medium but up to coarse, calcareous, phosphatic, glauconitic, moderate-olive-brown (5Y 4/4); rounded phosphate pebbles present

\section{UNCONFORMITY}

\section{Ashley Formation, Runnymede Marl Member}

Calcarenite, fine; mostly composed of foraminifera tests; contains sparse grains of very fine, soft, phosphate sand; olive (10Y 5/2).

\section{Bottomed in Ashley Formation, Runnymede Marl Member}


MS-7: $\quad 0.65 \mathrm{mi}$ east of western quadrangle border, $3.15 \mathrm{mi}$ south of northern quadrangle border, in west-central $1 / 9$ th of the quadrangle (latitude $33.0798^{\circ} \mathrm{N}$., longitude $80.4884^{\circ} \mathrm{W}$.). Surface elevation $54 \mathrm{ft}$.

\section{LITHOLOGY}

DEPTH, IN FEET

\section{Edisto River alluvium}

Sand, fine to coarse, poorly sorted, peaty, silty, clayey, soft, blackishred $(5 R 2 / 2)$. 0-3

Sand, fine to coarse, poorly sorted, thixotropic, soft, very-darkyellowish-brown (10YR 3/2); granules and pebbles of quartz at base

\section{UNCONFORMITY}

\section{Ashley Formation, Runnymede Marl Member}

Sand, fine, well-sorted, phosphatic, increasingly silty and clayey

downward, light-olive-brown ( $5 Y 5 / 4)$; foraminifera tests abundant; hit thin indurated layers intermittently during drilling.

Base of Edisto River alluvium:

$+31 \mathrm{ft}$ above sea level

Bottomed in Ashley Formation, Runnymede Marl Member 
MS-8: $\quad 1.3 \mathrm{mi}$ west of eastern quadrangle border, $3.8 \mathrm{mi}$ north of southern quadrangle border, in east-central 1/9th of the quadrangle (latitude $33.0556^{\circ} \mathrm{N}$., longitude $80.3975^{\circ}$ W.). Surface elevation $63 \mathrm{ft}$.

\section{LITHOLOGY}

DEPTH, IN FEET

\section{Penholoway formation}

Sand, fine to coarse, poorly sorted, clayey, silty; grayish brown $(5 Y R 3 / 2)$ over dark yellowish orange $(10 Y R 6 / 5)$

Sand, very fine to fine, clayey, silty, stiff, sticky; dark yellowish orange $(10 Y R 6 / 5)$ and mottled pale olive gray $(5 Y 7 / 1)$

Sand, fine to medium, silty; reddish orange (10R 5/6) and mottled pale olive gray $(5 Y 7 / 1)$ grading downward by $6 \mathrm{ft}$ to light grayish orange (10YR 7/4)

Clay, sandy (very fine), silty, stiff, sticky; yellowish gray (5Y8/1) and mottled yellowish orange $(10 Y R 7 / 6)$

Sand, very fine to fine; interbedded with clay, sandy and silty; quartz and phosphate gravel up to $2 \mathrm{~cm}$ in diameter at base; yellowish gray $(5 Y 8 / 1)$ and mottled yellowish orange $(10 Y R 7 / 6)$.

UNCONFORMITY

\section{Ashley Formation, Givhans Ferry Member}

Calcarenite, fine to medium, silty, sparsely phosphatic; pale yellowish gray $(5 Y 8 / 2)$ grading downward to moderate yellowish gray $(5 Y 6 / 2)$; grades downward to.

Calcarenite, fine to medium, silty, quartzose, phosphatic, glauconitic; phosphate lumps abundant near base; light olive brown (5Y 5/4) grading downward to moderate olive brown $(5 Y 4 / 4)$

\section{UNCONFORMITY}

\section{Ashley Formation, Runnymede Marl Member}

Calcarenite, mostly composed of foraminifera tests, no quartz or phosphate, light-olive-brown (5Y 5/4)...

Base of Penholoway formation:

Base of Ashley Formation, Givhans Ferry Member:

\section{Bottomed in Ashley Formation, Runnymede Marl Member}


MS-9: $3.5 \mathrm{mi}$ east of western quadrangle border, $1.8 \mathrm{mi}$ north of southern quadrangle border, in south-central $1 / 9$ th of the quadrangle (latitude $33.0262^{\circ} \mathrm{N}$., longitude $80.4399^{\circ}$ W.). Surface elevation $40 \mathrm{ft}$.

\section{LITHOLOGY}

DEPTH, IN FEET

\section{Edisto River alluvium}

Sand, fine to coarse, poorly sorted, slightly silty; light grayish brown $(5 Y R 4 / 2)$ and mottled dark yellowish brown (10YR 4/4), grading downward to dark yellowish orange (10YR 6/6)...

Sand, fine to medium, clayey, light-brownish-gray (5YR 6/1) $2-3$

Sand, fine to coarse, poorly sorted, grayish-orange (10YR 7/4). $3-6$

Sand, fine to very coarse, very poorly sorted, silty, soft, very-light-gray (N 8).

Sand, fine to very coarse, very poorly sorted, silty, moderate-olive-gray (5Y 4/2); contains granules and pebbles of quartz

\section{-UNCONFORMITY}

\section{Ashley Formation, Givhans Ferry Member}

Calcarenite, very fine to fine, increasingly quartzose and phosphatic downward, moderate-olive-brown (5Y 4/4); mostly consists of foraminifera tests; small black ( $N 1)$ phosphate pebbles and some quartz pebbles up to $1 \mathrm{~cm}$ in diameter in basal $2 \mathrm{ft}$

\section{Ashley Formation, Runnymede Marl Member}

Calcarenite, fine to medium, olive (10Y 4/4); mostly composed of foraminifera tests (some quite large)

Base of Edisto River alluvium:

Base of Ashley Formation, Givhans Ferry Member:
$+21 \mathrm{ft}$ above sea level $+8 \mathrm{ft}$ above sea level

\section{Bottomed in Ashley Formation, Runnymede Marl Member}


MS-10: $3.5 \mathrm{mi}$ east of western quadrangle border, $0.45 \mathrm{mi}$ south of northern quadrangle border, in north-central 1/9th of the quadrangle (latitude $33.1189^{\circ}$ N., longitude $80.4389^{\circ}$ W.). Surface elevation $107 \mathrm{ft}$.

\section{LITHOLOGY}

DEPTH, IN FEET

\section{Wicomico formation}

Sand, fine, well-sorted, clean; grayish brown (5YR 3/2) grading

downward to yellowish brown (10YR 5/4).

Sand, fine, well-sorted, clean; very fine to fine, dark heavy-mineral grains abundant below $4 \mathrm{ft}$; dark yellowish orange (10YR 6/6) grading downward through moderate yellowish brown (10YR 5/4) to yellowish brown $(10 Y R 5 / 2)$.

Sand, fine with bimodal medium to coarse fraction, yellowish-brown

$(10 Y R$ 5/2); very fine to fine, dark heavy-mineral grains abundant.

Sand, fine with bimodal medium to coarse fraction, thixotropic; very fine to fine, dark heavy-mineral grains abundant; yellowish orange (10YR 7/6) grading downward through dark grayish yellow (5Y 7/4) (17-21 ft) to light yellowish gray (5Y 8/2); grades downward to .

Sand, very fine to fine, silty, slightly clayey, coarsely micaceous, moderate-greenish-gray $(5 G Y 5 / 1)$

Silt, clayey, sandy (very fine to fine), sticky, micaceous, grading downward to clay, silty, sandy (very fine), sticky, micaceous; moderate greenish gray $(5 G Y 5 / 1)$; grades rapidly downward to

Sand, very fine to fine, silty, clayey, moderate-greenish-gray ( $5 G Y 5 / 1)$; black $(N 1)$ rough and lumpy phosphate pebbles up to $4 \mathrm{~cm}$ in diameter at base

\section{UNCONFORMITY}

\section{Ashley Formation, Givhans Ferry Member}

Sand, fine to coarse, very calcareous, phosphatic; phosphate pebbles and mollusk shell fragments in basal $1 \mathrm{ft}$; olive brown (5Y 3/6) grading downward to light olive brown $(5 Y 5 / 4)$

-UNCONFORMITY

\section{Ashley Formation, Runnymede Marl Member}

Calcarenite, fine, silty, dark-grayish-yellow (5Y 7/4); mostly composed of foraminifera tests; contains $2-5$ percent phosphate sand and small mollusk shell fragments up to very coarse size

Base of Wicomico formation:

Base of Ashley Formation, Givhans Ferry Member:

\section{Bottomed in Ashley Formation, Runnymede Marl Member}


MS-11: $2.3 \mathrm{mi}$ west of eastern quadrangle border, $4.05 \mathrm{mi}$ south of northern quadrangle border, in east-central $1 / 9$ th of the quadrangle (latitude $33.0668^{\circ} \mathrm{N}$., longitude $80.4145^{\circ}$ W.). Surface elevation $41 \mathrm{ft}$.

\section{LITHOLOGY}

DEPTH, IN FEET

\section{Edisto River alluvium}

Sand, fine to very coarse, poorly sorted, clean, loose; dark yellowish brown (10YR 4/4) grading downward to dusky yellowish orange $(10 Y R 5 / 6)$.

Sand, fine to very coarse, poorly sorted, subangular to subrounded, clean; contains sparse very fine to fine, dark heavy-mineral grains; pale yellowish brown (10YR 6/2) grading downward through yellowish orange $(10 Y R 7 / 6)$ to pale grayish orange $(10 Y R 8 / 4)$....

Sand, medium to granular, very poorly sorted, subangular to subrounded, clean, pale-grayish-orange (10YR 8/4)

Sand, fine to medium, clean, pale-yellowish-brown $(10 Y R$ 6/2)

Sand, medium to very coarse, poorly sorted, coarse to very coarse fraction subrounded to rounded, feldspathic, very-pale-yellowishbrown (10YR 7/2); contains scattered fine to medium, dark heavymineral grains

\section{-UNCONFORMITY}

\section{Ashley Formation, Givhans Ferry Member}

Calcarenite, fine, very phosphatic and quartzose; contains small rounded phosphate pebbles up to $1 \mathrm{~cm}$ in diameter at base; moderate olive brown (5Y 4/4) grading downward to moderate olive gray $(5 Y 4 / 2)$

UNCONFORMITY

\section{Ashley Formation, Runnymede Marl Member}

Calcarenite, fine, dark-grayish-yellow ( $5 Y 7 / 4)$; mostly composed of foraminifera tests; burrowed from above and burrows filled with quartzose and phosphatic sand....

Calcarenite, fine, more clayey than above, more stiff, dark-grayishyellow (5Y 7/4); mostly composed of foraminifera tests

Base of Edisto River alluvium:

Base of Ashley Formation, Givhans Ferry Member:

\section{Bottomed in Ashley Formation, Runnymede Marl Member}




\section{Ridgeville Quadrangle}

RI-99-1: $2.7 \mathrm{mi}$ east of western quadrangle border, $4.45 \mathrm{mi}$ south of northern quadrangle border, in central 1/9th of the quadrangle (latitude $33.0604^{\circ} \mathrm{N}$., longitude $80.3290^{\circ} \mathrm{W}$.). Surface elevation $38 \mathrm{ft}$.

\section{LITHOLOGY}

DEPTH, IN FEET

\section{Penholoway formation}

Sand, fine, well-sorted, increasingly clayey and silty downward; contains $1-2$ percent very fine, dark heavy-mineral grains; very dark yellowish brown (10YR 3/2) grading downward through light yellowish brown (10YR 6/4) to moderate brown (5YR 4/6) $0-3$

Sand, fine, well-sorted, clean, thixotropic, very-pale-orange (10YR 8/2) $3-6$

Sand, mostly fine but with scattered medium and coarse grains, clayey, finely micaceous; pale yellowish brown (10YR 7/2) grading downward to yellowish gray $(5 Y 7 / 2)$.

Sand, mostly fine but with scattered medium and coarse grains, wellsorted, silty, olive-brown $(5 Y 3 / 6)$.

\section{UNCONFORMITY}

\section{Ashley Formation, Givhans Ferry Member}

Calcarenite, fine; foraminifera tests very abundant; increasingly quartzose, phosphatic, and glauconitic downward; abundant rounded quartz and phosphate pebbles up to $1 \mathrm{~cm}$ in diameter in basal $2 \mathrm{ft}$; dusky yellow (5Y 6/6) grading downward $13 \mathrm{ft}$ to light olive brown (5Y 5/4) streaked olive brown (5Y 3/4); NP 24/25 nannofossil assemblage at $20 \mathrm{ft}$

\section{UNCONFORMITY}

\section{Ashley Formation, Runnymede Marl Member}

Calcarenite, fine, light-olive-brown (5Y 5/4); mostly composed of foraminifera tests; upper foot burrowed from above; NP 24/25 nannofossil assemblage at $50 \mathrm{ft}$

Calcarenite, fine, light-olive-brown ( $5 Y 5 / 4)$; foraminifera tests abundant; medium to coarse quartz grains and phosphate granules abundant

\section{Harleyville Formation, Osborn Member}

Calcarenite, fine, yellowish-gray (5Y 6/2); mostly composed of foraminifera tests; contains scattered small mollusk shell fragments; NP 21 nannofossil assemblage at $75 \mathrm{ft}$

\section{Bottomed in Harleyville Formation, Osborn Member}


RI-99-2: $3.3 \mathrm{mi}$ west of eastern quadrangle border, $0.45 \mathrm{mi}$ south of northern quadrangle border, in north-central $1 / 9$ th of the quadrangle (latitude $33.1181^{\circ} \mathrm{N}$., longitude $80.3072^{\circ} \mathrm{W}$.). Surface elevation $53 \mathrm{ft}$.

\section{LITHOLOGY}

DEPTH, IN FEET

\section{Penholoway formation}

Sand, dominantly fine to medium but ranging up to very coarse, clayey, silty; very dark yellowish brown (10YR 3/2) grading downward to dark yellowish orange $(10 Y R 6 / 6)$ $0-1$

Sand, fine, clayey, silty; dark yellowish orange (10YR 6/6) and mottled pale olive gray $(5 Y 6 / 2)$ grading downward to entirely pale olive gray $(5 Y 6 / 2)$

\section{UNCONFORMITY}

\section{Ashley Formation, Givhans Ferry Member}

Calcarenite, fine to medium, quartzose and phosphatic, clayey; dusky yellow (5Y 6/4) grading downward at $9 \mathrm{ft}$ to olive brown $(5 Y 3 / 4) \ldots$

\section{Ashley Formation, Runnymede Marl Member}

Calcarenite, fine, light-olive-gray (10Y 5/2); mostly composed of foraminifera tests; no quartz or phosphate sand; NP 24 nannofossil assemblage at $20 \mathrm{ft}$

Base of Penholoway formation:

Base of Ashley Formation, Givhans Ferry Member:

\section{Bottomed in Ashley Formation, Runnymede Marl Member}




\section{Rockville Quadrangle}

RO-1: $1.25 \mathrm{mi}$ west of eastern quadrangle border, $1.75 \mathrm{mi}$ south of northern quadrangle border, in northeast 1/9th of the quadrangle (latitude $32.5993^{\circ}$ N., longitude $80.1462^{\circ}$ W.). Surface elevation $7 \mathrm{ft}$.

\section{LITHOLOGY}

DEPTH, IN FEET

\section{Silver Bluff beds}

Sand, fine, well-sorted, thixotropic; dusky brown (5YR 2/2) grading downward through grayish brown $(5 Y R 3 / 2)(1-2 \mathrm{ft})$ and through dark yellowish orange $(10 Y R 6 / 6)(2-3 \mathrm{ft})$ to light yellowish gray $(10 Y 8 / 1)$.

Sand, fine, well-sorted, shelly, thixotropic; very fine, dark heavymineral grains abundant; moderate olive gray $(5 Y 5 / 1)$ grading downward at $8 \mathrm{ft}$ to medium bluish gray $(5 B 5 / 1)$......

Silt, clayey, sandy (very fine), medium-bluish-gray ( $5 B$ 5/1) $11-15$

\section{UNCONFORMITY}

\section{Wando Formation, upper member}

Sand, very fine to fine, silty, greenish-gray ( $5 G 6 / 1)$; shelly, including

Anadara ovalis, Noetia, Oliva, and Mulinia .....

Silt, clayey, sandy (very fine), greenish-gray (5G 6/1); Rangia shells present.

Shell hash and silt, greenish-gray $(5 G 6 / 1)$, interbedded

\section{UNCONFORMITY}

\section{Wando Formation, middle member}

Silt, clayey, sandy (very fine), greenish-gray ( $5 G 6 / 1)$.

Sand, very fine to fine, silty, clayey, shelly (mostly Mulinia), greenishgray $(5 G 6 / 1)$ $31-36$

Sand, fine, well-sorted, silty, sparsely shelly, greenish-gray (5G 6/1) $36-48$

Silt, clayey, sandy (very fine), finely micaceous, sparsely shelly, greenish-gray $(5 G 6 / 1)$.

Sand, fine to medium, greenish-gray $(5 G 6 / 1)$; contains abundant rounded light to black $(N 1)$ phosphate lumps up to $4 \mathrm{~cm}$ in diameter

\section{UNCONFORMITY}

\section{Ashley Formation, Runnymede Marl Member}

Calcarenite, fine to medium, slightly phosphatic, grayish-olive

(10Y 4/2); large foraminifera tests abundant; strong hydrogen sulfide

odor present

Base of Silver Bluff beds:

Base of Wando Formation, upper member:

Base of Wando Formation, middle member:

\section{Bottomed in Ashley Formation, Runnymede Marl Member}


RO-2: $3.35 \mathrm{mi}$ west of eastern quadrangle border, $1.65 \mathrm{mi}$ south of northern quadrangle border, in north-central 1/9th of the quadrangle (latitude $32.6009^{\circ}$ N., longitude $80.1826^{\circ}$ W.). Surface elevation $7 \mathrm{ft}$.

\section{LITHOLOGY}

DEPTH, IN FEET

\section{Silver Bluff beds}

Sand, fine; dusky brown (5Y 2/2) grading downward to grayish orange $(5 Y R 7 / 4)$

Sand, fine, well-sorted, increasingly silty downward, sparsely

micaceous; very fine, dark heavy-mineral grains abundant; grayish

orange (5YR 7/4) grading downward by $4 \mathrm{ft}$ to yellowish gray (10Y7/2)

Sand, fine, well-sorted, silty, shelly; very fine, dark heavy-mineral grains abundant; yellowish gray $(10 Y 7 / 2)$ grading downward through grayish olive $(10 Y 4 / 2)(15-18 \mathrm{ft})$ to medium dark gray $(N 4)$

Peat, dark-reddish-brown $(5 R 2 / 2)$.

Silt, clayey, sandy (very fine), dark-gray ( $N 3)$; thin layer of darkreddish-brown $(5 R 2 / 2)$ peat at $23 \mathrm{ft}$.

UNCONFORMITY

\section{Wando Formation, middle member}

Silt, clayey, much denser than above, grayish-green ( $5 G 5 / 2)$; contains sparse Mulinia $24-28$

Silt, clayey, dark-gray (N3); contains sparse Mulinia, Dinocardium, and oyster $28-32$

Sand, very fine to fine, silty, grayish-green $(5 G 5 / 2)$; shelly, including

Dinocardium, Mercenaria, oyster, and others

Silt, clayey, dense, sticky, dark-gray ( $N 3)$.

Sand, fine to coarse, poorly sorted, silty, shelly, dark-gray (N3);

contains lumps of Ashley lithology up to $1 \mathrm{~cm}$ in diameter $41-43$

-UNCONFORMITY

\section{Marks Head Formation}

Sand, fine to medium, phosphatic, dark-olive-brown (5Y2/4); contains lumps of Ashley lithology up to $3 \mathrm{~cm}$ in diameter on basal contact

\section{UNCONFORMITY}

\section{Ashley Formation, Runnymede Marl Member}

Calcarenite, fine, grayish-olive (10Y 4/2); contains large foraminifera tests, fragments of thin mollusk shells, and a fish spine; strong hydrogen sulfide odor present $47-66$

Base of Silver Bluff beds:

Base of Wando Formation, middle member: Base of Marks Head Formation:
$-17 \mathrm{ft}$ below sea level

$-36 \mathrm{ft}$ below sea level $-\mathbf{4 0} \mathrm{ft}$ below sea level

\section{Bottomed in Ashley Formation, Runnymede Marl Member}


RO-3: $2.05 \mathrm{mi}$ west of eastern quadrangle border, $3.8 \mathrm{mi}$ south of northern quadrangle border, in east-central 1/9th of the quadrangle (latitude $32.5704^{\circ} \mathrm{N}$., longitude $80.1600^{\circ} \mathrm{W}$.). Surface elevation $10 \mathrm{ft}$.

\section{LITHOLOGY}

DEPTH, IN FEET

\section{Holocene sand and silt}

Sand, fine, well-sorted; very fine, dark heavy-mineral grains abundant; yellowish gray $(5 Y 7 / 2)$ grading downward to very dark gray $(N 2)$.

Sand, fine, well-sorted, greenish-gray $(5 G 6 / 1)$; very fine, dark heavymineral grains and shell fragments abundant.

Silt, sandy (very fine), slightly clayey, greenish-gray ( $5 G 6 / 1)$; fulsome odor present

Sand, fine to very coarse, very poorly sorted, medium-dark-gray $(N 4)$; contains rounded granular quartz and phosphate grains; shelly, including Busycon, Mercenaria, and oyster

\section{UNCONFORMITY}

\section{Wando Formation, middle member}

Silt, clayey, sandy (very fine to fine), denser than above, greenish-gray $(5 G 6 / 1)$; thin layer of yellowish-gray $(5 Y 7 / 2)$ shell hash at $33 \mathrm{ft}$

Sand, silty, clayey, sparsely shelly, greenish-gray $(5 G 6 / 1)$

Sand, fine, well-sorted, greenish-gray $(5 G 6 / 1)$; very fine, dark heavymineral grains abundant; shells common but shell content decreases below $44 \mathrm{ft}$

Sand, fine to medium, yellowish-gray ( $5 Y 7 / 2)$; shells common; phosphate granules and pebbles up to $1 \mathrm{~cm}$ in diameter on basal boundary

\section{UNCONFORMITY}

\section{Marks Head Formation}

Sand, fine to medium, very phosphatic; phosphate lumps and mollusk steinkerns on basal surface; moderate olive brown (5Y3/4) grading downward to dark olive brown (5Y 2/4)

\section{UNCONFORMITY}

\section{Ashley Formation, Runnymede Marl Member}

Calcarenite, phosphatic; large foraminifera tests abundant; calcitecemented nodules abundant; medium olive brown (5Y 6/6) grading downward to grayish olive $(10 Y 4 / 2)$.

Base of Holocene sand and silt:

Base of Wando Formation, middle member:

Base of Marks Head Formation:

$-20 \mathrm{ft}$ below sea level

$-41 \mathrm{ft}$ below sea level $-46 \mathrm{ft}$ below sea level

\section{Bottomed in Ashley Formation, Runnymede Marl Member}


RO-4: $3.45 \mathrm{mi}$ west of eastern quadrangle border, $3.9 \mathrm{mi}$ south of northern quadrangle border, in central 1/9th of the quadrangle (latitude $32.5669^{\circ} \mathrm{N}$., longitude $80.1818^{\circ}$ W.). Surface elevation $7 \mathrm{ft}$.

\section{LITHOLOGY}

DEPTH, IN FEET

\section{Holocene sand and silt}

Sand, fine, well-sorted, clean; very fine, dark heavy-mineral grains abundant; dusky brown (5YR 2/2) grading downward through grayish brown $(5 Y R 3 / 2)$ to dusky yellow $(5 Y 6 / 4)$ then to very dark gray $(N 2)$

Sand, fine, well-sorted, clean, shelly (mostly Mulinia); very fine, dark heavy-mineral grains abundant; grayish orange (10YR 7/4) grading downward through greenish gray $(5 G 6 / 1)(3-5 \mathrm{ft})$ to grayish brown (10YR 3/2).

Sand, very fine to fine, silty, grayish-brown (10YR 3/2); oyster fragments abundant

Sand, dominantly very fine to fine but with scattered rounded medium to coarse grains, silty, clayey, grayish-brown (10YR 3/2); oyster fragments abundant; a few clayey silt lenses present in basal $3 \mathrm{ft}$

\section{Ashley Formation, Runnymede Marl Member}

Calcarenite, fine, phosphatic, grayish-olive (10Y 4/2); contains large coiled foraminifera test; hydrogen sulfide odor present

Base of Holocene sand and silt:

$-45 \mathrm{ft}$ below sea level

Bottomed in Ashley Formation, Runnymede Marl Member 
RO-5: $\quad 0.6 \mathrm{mi}$ east of western quadrangle border, $3.7 \mathrm{mi}$ south of northern quadrangle border, in west-central 1/9th of the quadrangle (latitude $32.5717^{\circ} \mathrm{N}$., longitude $80.2397^{\circ}$ W.). Surface elevation $10 \mathrm{ft}$.

\section{LITHOLOGY}

DEPTH, IN FEET

\section{Wando Formation, upper member}

Sand, fine to medium, poorly sorted, subangular to subrounded, clean; dusky brown (5YR 2/2) grading downward to dark yellowish orange (10YR 5/6). $0-1$

Sand, medium to coarse, coarse grains subrounded to rounded, clean; very fine, dark heavy-mineral grains present; grayish orange $(10 Y R 6 / 4)$ grading downward through dark yellowish orange $(10 Y R 6 / 6)(2-3 \mathrm{ft})$ and through pale orange $(10 Y R 7 / 2)(3-4 \mathrm{ft})$ back through dark yellowish orange $(10 Y R 6 / 6)(4-6 \mathrm{ft})$ to grayish yellow $(5 Y 7 / 4)$ $1-10$

Sand, medium to coarse, clean, grayish-yellow ( $5 Y 7 / 4)$; contains about 20 percent rounded phosphate grains.

Sand, fine to coarse, poorly sorted, coarse fraction rounded, phosphatic, shelly, grayish-yellow (5Y 7/4); calcite-cemented lumps abundant.

Sand, very fine, silty, clayey, medium-greenish-gray $(5 G Y 5 / 1)$.... $19-19.3$

Sand, fine, well-sorted, grading downward to fine to medium, silty, shelly; very fine, dark heavy-mineral grains abundant; medium greenish gray $(5 G Y 5 / 1)$.

Sand, fine to coarse, poorly sorted, shelly, greenish-gray $(5 G Y 5 / 1)$. 34-38

Sand, very fine, silty, clayey, dark-greenish-gray $(5 G 4 / 1)$ $38-38.3$

Sand, dominantly fine but contains scattered medium to coarse grains, silty, shelly, dark-greenish-gray $(5 G 4 / 1)$; very fine, dark heavy-mineral grains abundant

UNCONFORMITY

\section{Marks Head Formation}

Sand, fine, silty, clayey, phosphatic; contains medium to coarse rounded quartz and phosphate sand in basal foot; yellowish gray $(5 Y 7 / 2)$ grading downward at $58.5 \mathrm{ft}$ to olive brown $(5 Y 3 / 4)$

UNCONFORMITY

\section{Ashley Formation, Runnymede Marl Member}

Calcarenite, fine grading downward in basal foot to fine to medium, very phosphatic, slightly quartzose, silty, moderate-olive-brown (5Y 4/4); angular phosphate pebbles up to $2.5 \mathrm{~cm}$ in diameter common on basal contact

\section{UNCONFORMITY}

\section{Harleyville Formation, Osborn Member}

Calcarenite, fine, more silty and clayey than above, light-olive-brown (5Y 5/4); mostly composed of foraminifera tests; sharp basal contact. 
Parkers Ferry Formation

Calcilutite, slightly silty, stiff, dense, medium-greenish-gray (5GY 5/1);

sparse foraminifera tests visible.

$86-96$

Base of Wando Formation, upper member:

Base of Marks Head Formation:

Base of Ashley Formation, Runnymede Marl Member:

Base of Harleyville Formation, Osborn Member:

$-44 \mathrm{ft}$ below sea level

$-56 \mathrm{ft}$ below sea level

$-70 \mathrm{ft}$ below sea level

$-76 \mathrm{ft}$ below sea level

Bottomed in Parkers Ferry Formation 
RO-6: $2.25 \mathrm{mi}$ east of western quadrangle border, $1.0 \mathrm{mi}$ south of northern quadrangle border, in northwest 1/9th of the quadrangle (latitude $32.6107^{\circ}$ N., longitude $80.2113^{\circ} \mathrm{W}$.). Surface elevation $8 \mathrm{ft}$.

\section{LITHOLOGY}

DEPTH, IN FEET

\section{Wando Formation, upper member}

Sand, fine, well-sorted, clean; very fine, dark heavy-mineral grains abundant; sparse fine-size mica; very pale brown (5YR 6/2) grading downward through orange $(10 Y R 7 / 4)(0.5-1.0 \mathrm{ft})$ to medium orange $(10 Y R 7 / 6)$

Sand, fine, well-sorted, clean, moderate-brown (5YR 4/4); very fine, dark heavy-mineral grains abundant.

Sand, fine, well-sorted, clean, dark-grayish-orange (10YR 6/4); very

fine, dark heavy-mineral grains abundant; fine-size mica flakes

abundant; sparsely shelly below $20 \mathrm{ft}$ and then very shelly $(25-28 \mathrm{ft}$ )

with calcite-cemented lumps of sand common

Sand, fine, silty, shelly, light-olive-gray ( $5 Y 5 / 2)$

Silt, clayey, soft, greasy, micaceous, sparsely shelly, dark-greenishgray $(5 G Y 4 / 1)$

Sand, fine, grading downward by basal foot to fine to medium, silty, shelly (many Mulinia and one Noetia), medium-greenish-gray $(5 G Y 5 / 1)$

\section{UNCONFORMITY}

\section{Wando Formation, middle member}

Silt, clayey, sandy (very fine); contains scattered laminae of sand, very

fine, moderately dense, micaceous; roots in top 3 in.; dark grayish

green $(5 G Y 4 / 2)$ grading downward at $45 \mathrm{ft}$ to dark greenish gray

$(5 G 3 / 1)$

Sand, fine to medium, silty, soft, phosphatic, shelly including Mulinia

and Polinices, greenish-gray ( $5 G 5 / 1)$; grades rapidly downward to.....

Shell hash, mostly composed of fragment of Mulinia and oyster, fine to medium sand matrix, silty, greenish-gray $(5 G 5 / 1)$.

\section{Ashley Formation, Givhans Ferry Member}

Calcarenite, fine, quartzose and phosphatic; foraminifera tests abundant; medium olive gray $(5 Y 4 / 2)$ grading downward at $61 \mathrm{ft}$ to moderate olive brown $(5 Y 4 / 4)$. $60-66$

Base of Wando Formation, upper member: Base of Wando Formation, middle member:

\section{Bottomed in Ashley Formation, Givhans Ferry Member}




\section{Summerville Northwest Quadrangle}

SN-99-1: $\quad 1.65 \mathrm{mi}$ east of western quadrangle border, $0.35 \mathrm{mi}$ north of southern quadrangle border, in southwest $1 / 9$ th of the quadrangle (latitude $33.1308^{\circ}$ N., longitude $80.2220^{\circ}$ W.). Surface elevation $72 \mathrm{ft}$.

\section{LITHOLOGY}

DEPTH, IN FEET

\section{Penholoway formation}

Sand, fine to coarse, poorly sorted, subangular to subrounded, clayey, silty; very dark yellowish brown (10YR 3/2) grading downward to dark grayish orange $(10 Y R 6 / 4)$..... $0-1$

Sand, very fine to fine, clayey, silty, dense, stiff; pale yellowish brown $(10 Y R 6 / 2)$ grading downward to yellowish gray $(5 Y 7 / 2)$

Sand, fine to medium, orange (10YR 5/6); interbedded with clay, sandy, stiff, yellowish-gray $(5 Y 8 / 1)$.

Clay, sandy (very fine), silty, stiff; pale olive gray (5Y6/2) and mottled dark yellowish brown $(10 Y R$ 4/6) $11-19$

Sand, fine to medium, olive (10Y4/4)

-UNCONFORMITY-

\section{Goose Creek Limestone}

Calcarenite, phosphatic, medium-greenish-gray (5GY7/1); contains calcite-cemented lumps, rounded phosphate pebbles up to $2 \mathrm{~cm}$ in diameter, and shell fragments of Pecten eboreus, Dinocardium, and oysters among others

-UNCONFORMITY-

\section{Ashley Formation, Givhans Ferry Member}

Calcarenite, fine, quartzose, phosphatic, glauconitic; phosphate pebbles up to $2 \mathrm{~cm}$ in diameter at base; pale yellowish brown (10YR 7/2) grading downward to moderate olive brown $(5 Y 4 / 6)$.....

\section{-UNCONFORMITY}

\section{Ashley Formation, Runnymede Marl Member}

Calcarenite, fine, light-olive-brown (5Y 5/4); mostly composed of foraminifera tests; sparse very fine phosphate grains present..

Base of Penholoway formation:

Base of Goose Creek Limestone:

Base of Ashley Formation, Givhans Ferry Member:

\section{Bottomed in Ashley Formation, Runnymede Marl Member}

$+51 \mathrm{ft}$ above sea level $+47 \mathrm{ft}$ above sea level $+44 \mathrm{ft}$ above sea level 


\section{Wadmalaw Island Quadrangle}

WA-1: $0.95 \mathrm{mi}$ west of eastern quadrangle border, $1.65 \mathrm{mi}$ north of southern quadrangle border, in southeast 1/9th of the quadrangle (latitude $32.6487^{\circ}$ N., longitude $80.1407^{\circ} \mathrm{W}$.). Surface elevation $8 \mathrm{ft}$.

\section{LITHOLOGY}

DEPTH, IN FEET

\section{Wando Formation, upper member}

Sand, fine, well-sorted, brownish-gray (5YR 4/1).

Sand, fine, well-sorted, micaceous, thixotropic below $6 \mathrm{ft}$; very fine, dark heavy-mineral grains present; dusky yellow (5Y 6/4) grading downward through light yellowish gray $(5 Y 8 / 1)(3-6)$ to yellowish gray $(5 Y 7 / 2)$

Sand, fine, well-sorted, micaceous, thixotropic; very fine, dark heavymineral grains common; grayish orange (10YR 7/4) grading downward at $19 \mathrm{ft}$ to dark yellowish orange (10YR 6/6)

Sand, fine, well-sorted, thixotropic, medium-bluish-gray ( $5 B 5 / 1)$; very

fine, dark heavy-mineral grains common; shelly, mostly Mulinia

fragments at top but fauna becomes more diverse near base including

Anadara ovalis, Mercenaria, Oliva, oyster, and others

\section{UNCONFORMITY}

\section{Wando Formation, middle member}

Silt, sandy (very fine to fine), clayey, stiff, medium-dark-gray ( $N 4)$;

Mulinia shells present; grades downward to.

Sand, very fine to fine, silty, sparsely shelly including Mulinia and

Mercenaria, medium-dark-gray $(N 4)$

Gravel, composed of black $(N 1)$ rounded phosphate pebbles up to $3 \mathrm{~cm}$

in diameter.....

\section{UNCONFORMITY-}

\section{Ashley Formation, Runnymede Marl Member}

Calcarenite, fine, well-sorted, slightly silty, semi-indurated; dusky

yellow (5Y 6/4) mixed with dark olive brown $(5 Y 2 / 4)$

Calcarenite, fine, phosphatic, grayish-olive ( $5 Y 4 / 2)$; contains large

Base of Wando Formation, upper member:

Base of Wando Formation, middle member:

$-24 \mathrm{ft}$ below sea level $-38 \mathrm{ft}$ below sea level

\section{Bottomed in Ashley Formation, Runnymede Marl Member}


WA-2: $2.55 \mathrm{mi}$ west of eastern quadrangle border, $1.72 \mathrm{mi}$ south of northern quadrangle border, in northeast $1 / 9$ th of the quadrangle (latitude $32.7249^{\circ} \mathrm{N}$., longitude $80.1519^{\circ}$ W.). Surface elevation $14 \mathrm{ft}$.

\section{LITHOLOGY}

DEPTH, IN FEET

\section{Wando Formation, upper member}

Sand, fine, well-sorted, silty, grayish-brown (5YR 3/2). $0-1$

Sand, fine with a minor rounded coarse fraction; grayish brown (5YR 3/2) grading downward through grayish orange (10YR 7/4)

(3-5 ft) to yellowish gray $(5 Y 7 / 2)$; grades downward to

Sand, fine with a minor rounded coarse fraction, silty, micaceous, shelly below $12 \mathrm{ft}$ (mostly Mulinia); medium dark gray ( $N 3$ ) grading downward in basal foot to greenish gray $(5 G 6 / 1)$.....

Silt, clayey, sandy (very fine), greenish-gray $(5 G 6 / 1)$

Sand, fine to coarse, poorly sorted, silty, clayey, stiff, bright-grayishgreen (10GY 5/2); small phosphate pebbles present near base

Sand, fine to coarse, poorly sorted, bright-grayish-green (10GY 5/2); contains abundant clasts from unit below.

\section{UNCONFORMITY}

\section{Ashley Formation, Runnymede Marl Member}

Calcarenite, fine to medium, phosphatic, grayish-olive $(10 Y 4 / 2)$; contains abundant calcite-cemented lumps

Calcarenite, fine, indurated to semi-indurated; very tough drilling, no intact recovery $32-36$

Calcarenite, fine, grayish-olive (10Y 4/2) $36-45$

Calcarenite, fine, phosphatic and slightly quartzose, grayish-olive (10Y 4/2) $45-61$

Base of Wando Formation, upper member:

$-16 \mathrm{ft}$ below sea level

\section{Bottomed in Ashley Formation, Runnymede Marl Member}


WA-3: $3.65 \mathrm{mi}$ east of western quadrangle border, $3.9 \mathrm{mi}$ north of southern quadrangle border, in central 1/9th of the quadrangle (latitude $32.6823^{\circ}$ N., longitude $80.1877^{\circ}$ W.). Surface elevation $23 \mathrm{ft}$.

\section{LITHOLOGY}

DEPTH, IN FEET

\section{Wando Formation, upper member}

Sand, fine, well-sorted, silty; grayish orange (10YR 7/4) grading downward through dusky brown (5YR 2/2) (3-3.5 ft) and through light yellowish gray $(5 Y 8 / 1)(3.5-4 \mathrm{ft})$ back to dusky brown $(5 Y R 2 / 2)$

Sand, fine, well-sorted, silty, finely micaceous; dusky yellowish brown

(10YR 2/2) grading downward through dark olive gray $(5 Y 2 / 1)$

(11-17 ft) to medium gray $(N 5)$.

Sand, fine, well-sorted, silty, finely micaceous, shelly, greenish-gray

$(5 G 5 / 1)$; very fine, dark heavy-mineral grains abundant

Sand, fine, silty, clayey, dense, grayish-green (10GY 5/2)

Sand, fine, grayish-green (10GY 5/2); shelly, mostly Mulinia with one

Dinocardium fragment

Silt, clayey, sandy (very fine), dense, medium-olive-gray (5Y 5/1);

shelly, mostly Mulinia but with one Anadara brasiliana

\section{Marks Head Formation}

Sand, fine, well-sorted, silty, finely micaceous, medium-olive-brown (5Y 3/4); rounded medium phosphate grains abundant; lumps of Ashley lithology and small phosphate pebbles less than $1 \mathrm{~cm}$ in diameter in basal $2 \mathrm{ft}$ of interval

\section{Ashley Formation, Runnymede Marl Member}

Calcarenite, fine to medium, phosphatic, large foraminifera tests common, grayish-olive $(10 Y 4 / 2)$

Base of Wando Formation, upper member:

Base of Marks Head Formation:

$-21 \mathrm{ft}$ below sea level

Bottomed in Ashley Formation, Runnymede Marl Member 
WA-4: $1.15 \mathrm{mi}$ east of western quadrangle border, $4.55 \mathrm{mi}$ north of southern quadrangle border, in east-central $1 / 9$ th of the quadrangle (latitude $32.6843^{\circ} \mathrm{N}$., longitude $80.1448^{\circ}$ W.). Surface elevation $11 \mathrm{ft}$.

\section{LITHOLOGY}

DEPTH, IN FEET

\section{Wando Formation, upper member}

Sand, very fine to fine, silty; light yellowish gray (5Y 8/1) grading downward to medium gray $(N 5)$ and mottled dark yellowish orange $(10 Y R$ 6/6)

Sand, fine, well-sorted; bright orange (10YR 5/5) grading downward to medium olive gray $(5 Y 5 / 1)$.

Sand, fine, shelly, medium-olive-gray $(5 Y 5 / 1)$ 6-7

Sit, clayey, dense, grayish-green $(5 G 5 / 2)$

Sand, fine, silty, greenish-gray ( $5 G 6 / 1)$; dark heavy-mineral grains abundant; shelly, mostly Mulinia but also Anadara ovalis and snail shells present

Sand, medium to coarse, coarse grains subrounded to rounded, silty, shelly, greenish-gray $(5 G 6 / 1)$

\section{UNCONFORMITY}

\section{Wando Formation, middle member}

Silt, clayey, sandy (very fine), medium-dark-gray ( $N 4)$

Sand, fine to coarse, poorly sorted, clayey, silty, medium-dark-gray

$(N 4)$; contains rounded lumps of phosphate and lumps of reworked

Ashley Formation up to $3 \mathrm{~cm}$ in diameter

UNCONFORMITY

\section{Ashley Formation, Givhans Ferry Member}

Calcarenite, fine to medium, quartzose, phosphatic, light-olive-gray

(5Y 5/2); indurated lumps common

\section{UNCONFORMITY}

\section{Ashley Formation, Runnymede Marl Member}

Calcarenite, fine to medium, phosphatic, grayish-olive (10Y4/2); large

foraminifera tests common and thin mollusk shell fragments

moderately common $39-41$

Base of Wando Formation, upper member:

Base of Wando Formation, middle member:

Base of Ashley Formation, Givhans Ferry Member:
$-18 \mathrm{ft}$ below sea level $-24 \mathrm{ft}$ below sea level $-28 \mathrm{ft}$ below sea level

\section{Bottomed in Ashley Formation, Runnymede Marl Member}


WA-5: $3.55 \mathrm{mi}$ west of eastern quadrangle border, $1.05 \mathrm{mi}$ north of southern quadrangle border, in south-central $1 / 9$ th of the quadrangle (latitude $32.6402^{\circ} \mathrm{N}$., longitude $80.1855^{\circ}$ W.). Surface elevation $15 \mathrm{ft}$.

\section{LITHOLOGY}

DEPTH, IN FEET

\section{Wando Formation, upper member}

Sand, fine, well-sorted, dark-grayish-orange (5YR 5/4). $0-1$

Sand, fine, well-sorted, thixotropic; light yellowish gray $(5 Y 8 / 1)$

grading downward to grayish orange (10YR 7/4) .....

Sand, fine, well-sorted, silty, micaceous, medium-olive-gray (5Y 5/1);

very fine, dark heavy-mineral grains abundant.

Sand, fine, well-sorted, silty, micaceous, medium-bluish-gray (5B 5/1);

very fine, dark heavy-mineral grains abundant; shelly, mostly Mulinia

at top but molluscan fauna more diverse downward.

Silt, clayey, sandy (very fine to fine), grayish-green $(5 G 5 / 2)$

Sand, fine, well-sorted, silty, very shelly including Anadara ovalis and A. brasiliana, grayish-green $(5 G 5 / 2)$

Silt, clayey, dense, dark-gray (N 3)

Sand, very fine to fine, silty, shelly, dark-gray (N 3)

Sand, dominantly medium but fine to coarse, poorly sorted, silty, shelly including Noetia and snails, dark-gray (N3); contains a few phosphate pebbles near basal contact....

\section{UNCONFORMITY}

\section{Wando Formation, middle member}

Silt, clayey, carbonaceous; brownish gray $(5 Y R 4 / 1)$ grading downward

to dusky brown $(5 Y R 2 / 2)$

Sand, fine, well-sorted, silty, clayey, contains shell fragments of

Mercenaria and oyster; medium dark gray $(N 4)$ grading downward to

medium greenish gray $(5 G Y 5 / 1)$

UNCONFORMITY

\section{Ashley Formation, Runnymede Marl Member}

Calcarenite, fine, phosphatic, grayish-olive (10Y 4/2); contains large

foraminifera tests and fragments of thin mollusk shells; odor of

hydrogen sulfide present.

Base of Wando Formation, upper member:

Base of Wando Formation, middle member:

$-24 \mathrm{ft}$ below sea level

$-37 \mathrm{ft}$ below sea level

\section{Bottomed in Ashley Formation, Runnymede Marl Member}


WA-6: $1.15 \mathrm{mi}$ east of western quadrangle border, $3.85 \mathrm{mi}$ south of northern quadrangle border, in west-central $1 / 9$ th of the quadrangle (latitude $32.6937^{\circ} \mathrm{N}$., longitude $80.2309^{\circ}$ W.). Surface elevation $15 \mathrm{ft}$.

\section{LITHOLOGY}

DEPTH, IN FEET

\section{Wando Formation, upper member}

Sand, fine, well-sorted, silty; grayish brown (5YR 3/2) grading

downward to dark yellowish orange (10YR 6/6) and mottled grayish

yellow $(5 Y 7 / 4)$

Sand, fine, clayey, silty, yellowish-gray $(5 Y 7 / 2)$; medium to coarse-

size mica flakes abundant; contains sparse very fine, dark heavy-

mineral grains

Sand, fine, slightly silty, grayish-yellow (5Y 7/4); contains sparse very

fine, dark heavy-mineral grains

Sand, fine, silty, clayey, micaceous; grayish yellow (5Y7/4) and

mottled dark yellowish orange (10YR 6/6)

Sand, fine, silty, clayey below $15 \mathrm{ft}$, sparsely micaceous, sparsely

shelly, medium-greenish-gray ( $5 G Y 5 / 1)$; contains sparse very fine,

dark heavy-mineral grains .....

-UNCONFORMITY

\section{Goose Creek Limestone}

Sand, medium, very calcareous and phosphatic, medium-greenish-gray

( $5 G Y 5 / 1)$; full of indurated lumps with knobbly surfaces; sparse bits of aragonitic shells and oyster fragments on basal contact as well as rounded phosphate lumps up to $1 \mathrm{~cm}$ in diameter and discoidal to spherical in shape.

\section{UNCONFORMITY}

\section{Marks Head Formation}

Sand, fine, silty, dense; olive gray ( $5 Y 3 / 4)$ grading downward through moderate olive brown $(5 Y 4 / 4)(36-43 \mathrm{ft})$ then back to olive gray

$(5 Y 3 / 4)$

\section{UNCONFORMITY}

\section{Ashley Formation, Runnymede Marl Member}

Calcarenite, fine, silty, sparsely phosphatic and quartzose, moderate-

olive-brown (5Y 4/4); rare mollusk shells present

Calcarenite, fine, sparsely phosphatic and quartzose, silty, moderate-

olive-brown (5Y 4/4); contains occasional large foraminifera tests. $81-106$

Base of Wando Formation, upper member:

$-12 \mathrm{ft}$ below sea level

Base of Goose Creek Limestone:

$-20 \mathrm{ft}$ below sea level

Base of Marks Head Formation:

$-46 \mathrm{ft}$ below sea level

\section{Bottomed in Ashley Formation, Runnymede Marl Member}


WA-7: $1.7 \mathrm{mi}$ east of western quadrangle border, $1.7 \mathrm{mi}$ north of southern quadrangle border, in southwest 1/9th of the quadrangle (latitude $32.6500^{\circ}$ N., longitude $80.2213^{\circ}$ W.). Surface elevation $8 \mathrm{ft}$.

\section{LITHOLOGY}

DEPTH, IN FEET

\section{Wando Formation, upper member}

Sand, fine, well-sorted, silty and slightly micaceous below $0.5 \mathrm{ft}$; grayish yellow (5Y 7/4) grading downward to dark yellowish orange (10YR 6/6)

Sand, fine, silty, micaceous, clayey between 4-5 ft; reddish brown $(10 R 5 / 6)$ grading downward through medium greenish gray $(5 Y 5 / 1)$ (4-5 ft) to light olive brown (5Y 5/4)

Sand, fine grading downward by $21 \mathrm{ft}$ to fine to medium, silty, shelly (Mulinia, oyster, and rare Mercenaria), medium-grayish-olive (10Y 5/2); contains scattered 1 - to 4 -in.-thick clay lenses; grades rapidly downward to

Silt, clayey, sandy (very fine to coarse), medium-grayish-olive (10Y 5/2); lumps of rounded Marks Head lithology at base

\section{Marks Head Formation}

Sand, fine grading downward by $37 \mathrm{ft}$ to fine to medium, well-sorted, medium to coarse in basal foot with subangular phosphate granules; contains sparse foraminifera tests; olive brown (5Y3/4) grading downward through moderate grayish yellow $(5 Y 7 / 4)$ to moderate olive brown $(5 Y 4 / 4)$

\section{Ashley Formation, Runnymede Marl Member}

Calcarenite, fine, sparsely shelly, moderate-olive-brown (5Y 6/6);

mostly composed of foraminifera tests

Calcarenite, fine, sparsely phosphatic; mostly composed of foraminifera tests; contains sparse pectinid shells; light olive brown (5Y 5/4) grading downward by $79 \mathrm{ft}$ to moderate olive brown $(5 Y$ 4/4);

Base of Wando Formation, upper member:

\section{Bottomed in Ashley Formation, Runnymede Marl Member}


WA-8: $1.05 \mathrm{mi}$ east of western quadrangle border, $1.45 \mathrm{mi}$ south of northern quadrangle border, in northwest $1 / 9$ th of the quadrangle (latitude $32.7283^{\circ} \mathrm{N}$., longitude $80.2322^{\circ} \mathrm{W}$.). Surface elevation $18 \mathrm{ft}$.

\section{LITHOLOGY}

DEPTH, IN FEET

\section{Wando Formation, upper member}

Sand, fine, clean; dark yellowish brown (10YR 4/2), very pale yellowish brown (10YR 7/2), and yellowish orange (10YR 7/6) intermingled $0-1$

Sand, fine, well-sorted, silty grading downward to silty and clayey at $4 \mathrm{ft}$, micaceous; very fine, dark heavy-mineral grains abundant; dark yellowish orange $(10 Y R$ 5/6) grading downward through yellowish orange $(10 Y R 7 / 6)(2-4 \mathrm{ft})$ to yellowish gray $(5 Y 7 / 2)$

Sand, very fine to fine, silty; very fine, dark heavy-mineral grains abundant; yellowish gray $(5 Y 7 / 2)$ and mottled dark yellowish orange $(10 Y R 5 / 6)$ and yellowish orange (10YR 7/6)

Silt, clayey, sandy (very fine), very-dark-greenish-gray (5GY 3/1). $11-18$

Sand, fine, silty, sparsely shelly, very-dark-greenish-gray (5GY 3/1) $18-22$

Silt, clayey, sandy (very fine), very-dark-greenish-gray (5GY3/1).

Sand, fine to medium grading downward to medium to coarse, silty, sparsely shelly, medium-greenish-gray $(5 G Y 5 / 1)$

\section{Daniel Island beds}

Silt, clayey, stiff, dark-greenish-gray ( $5 G Y 3 / 1)$; wood streaks below $33 \mathrm{ft}$; basal $3 \mathrm{ft}$ sparsely shelly; very sticky and tough to get off stems

Sand, medium to coarse, silty, dark-greenish-gray (5GY3/1); contains scattered lumps of phosphate and Ashley lithology up to $4 \mathrm{~cm}$ in diameter

\section{UNCONFORMITY}

\section{Ashley Formation, Runnymede Marl Member}

Calcarenite, fine; mostly composed of foraminifera tests; light olive brown (5Y 5/4) grading downward through very light olive gray $(5 Y 6 / 2)$ then back to light olive brown $(5 Y 5 / 4)$; very light olive gray areas semi-indurated

Base of Wando Formation, upper member: Base of Daniel Island beds:

\section{Bottomed in Ashley Formation, Runnymede Marl Member}


WA-9: $3.45 \mathrm{mi}$ east of western quadrangle border, $1.6 \mathrm{mi}$ south of northern quadrangle border, in north-central $1 / 9$ th of the quadrangle (latitude $32.7268^{\circ} \mathrm{N}$., longitude $80.1903^{\circ}$ W.). Surface elevation $10 \mathrm{ft}$.

\section{LITHOLOGY}

DEPTH, IN FEET

\section{Wando Formation, upper member}

Sand, fine, well-sorted, slightly silty; grayish brown $(5 Y R 3 / 2)$ grading downward to grayish orange $(10 Y R 7 / 4)$ mixed with yellowish gray

$(5 Y 7 / 2)$

Sand, fine to medium, poorly sorted, subangular to subrounded, slightly

silty and clayey; grayish yellow (5Y 7/4) and mottled orange (10YR 5/6)

Sand, fine, silty, clayey, stiff; very fine, dark heavy-mineral grains present; light brownish gray $(5 Y R$ 6/1) grading downward to medium greenish gray $(5 G 6 / 1)$; grades downward to.

Silt, clayey, sandy (very fine), slightly micaceous, medium-greenishgray $(5 G 6 / 1)$; contains scattered lenses of very fine sand; grades rapidly downward to.

Sand, fine to medium, poorly sorted, very silty, medium-greenish-gray

(5GY 5/1); contains sparse oyster shell fragments; a few clayey

stringers and sparse shells of Mulinia present below $31 \mathrm{ft}$; grades

downward to

Sand, medium to coarse, poorly sorted, very silty, medium-greenishgray (5GY 5/1); fragments of Mulinia and oyster shells common

\section{Ashley Formation, Runnymede Marl Member}

Calcarenite, fine; composed mostly of foraminifera tests but also of sparse thin mollusk shell fragments; yellowish gray $(5 Y 7 / 2)$ at top but grading downward at $39.5 \mathrm{ft}$ to moderate olive brown $(5 Y 4 / 4)$....

Calcarenite, slightly quartzose and phosphatic, moderate-olive-brown (5Y 4/4); composed mostly of foraminifera tests but also of sparse thin mollusk shell fragments

\section{Bottomed in Ashley Formation, Runnymede Marl Member}

